Portland State University

PDXScholar

Fall 1-25-2019

\title{
"Beneath this Sod": Intersections of Colonialism, Urbanization, and Memory in the Cemeteries of Salem and Portland, Oregon
}

Kirsten Makenna Straus

Portland State University

Follow this and additional works at: https://pdxscholar.library.pdx.edu/open_access_etds

Part of the United States History Commons

Let us know how access to this document benefits you.

Recommended Citation

Straus, Kirsten Makenna, " "Beneath this Sod": Intersections of Colonialism, Urbanization, and Memory in the Cemeteries of Salem and Portland, Oregon" (2019). Dissertations and Theses. Paper 4938.

https://doi.org/10.15760/etd.6814

This Thesis is brought to you for free and open access. It has been accepted for inclusion in Dissertations and Theses by an authorized administrator of PDXScholar. Please contact us if we can make this document more accessible: pdxscholar@pdx.edu. 
"Beneath this Sod": Intersections of Colonialism, Urbanization, and Memory in the Cemeteries of Salem and Portland, Oregon

\author{
by \\ Kirsten Makenna Straus
}

A thesis submitted in partial fulfillment of the requirements for the degree of

Master of Arts

in

History

Thesis Committee:

Catherine McNeur, Chair

Katrine Barber

Tim Garrison

Naomi Adiv

Portland State University

2018 
(C) 2018 Kirsten Makenna Straus 
Abstract

Despite the large amount of research about the colonization of the American West Coast, historians have overlooked the subtle yet significant role that cemeteries have played in this narrative. Using evidence from archives, newspapers, and historical maps, this study identifies the forces which influenced the development and use of cemeteries in Portland and Salem, Oregon during the nineteenth and twentieth centuries. In Salem, the reinterpretation of the story of Methodist Mission leader Jason Lee culminated in an elaborate reinterment ceremony nearly sixty years after his death at the cemetery he had helped found. By contrast, the remains of Indigenous children who died while attending Lee's mission school and those who died while patients at the Oregon Insane Asylum are now lost, though they were buried only a few hundred feet from Lee's eventual resting place. In Portland, the city government left behind a wake of tangled paperwork and actual bodies in its failed attempts to provide early Portlanders with a space for the dead. Finally, a private group founded a large, modern cemetery akin to the world-famous Green-wood or Mount Auburn Cemeteries on the East Coast. Portlanders had finally addressed the "last great necessity" of the city, and were ready for more residents and more investors. Studying the development and history of cemeteries in Oregon is a unique and underutilized way to understand how the forces of colonization, urbanization, and memory manifest in both the shared memories and physical landscapes of our communities. 
Acknowledgments

I would like to extend a warm thank you to the members of my thesis committee, including Professors Katrine Barber, Tim Garrison, and Naomi Adiv, and the Chair, Catherine McNeur for lending their experience, mentorship, and knowledge to me during the graduate process. The many excellent classes I took with Professors Barber and McNeur were especially informative and greatly influential in my understanding of this topic. Thank you.

I would like to thank my professional mentors, Kimberli Fitzgerald, Sally Long, Eliza Canty-Jones, and Erin Brassell, who lent their expertise, support, and time to me during this process.

The staff at many archival institutions I visited also deserve a thank you for their expertise, encouragement, and help in locating these records: Kylie Pine at the Willamette Heritage Center, and staff at the Oregon Historical Society and City of Portland Archive. A thank you is also in order for Gary Kniss and Trey Anderson of the I.O.O.F. who allowed me to utilize their records for this research.

A big thank you goes to my husband, Dillon Peck, whom I made read this whole thing at least twice and the introduction/conclusion at least ten times. I also made him visit Mount Auburn Cemetery in 100-degree weather on our honeymoon trip. He was not even grumpy about it, and don't worry, I bought him a beer. 
Table of Contents

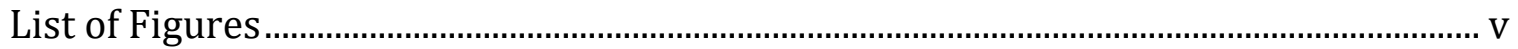

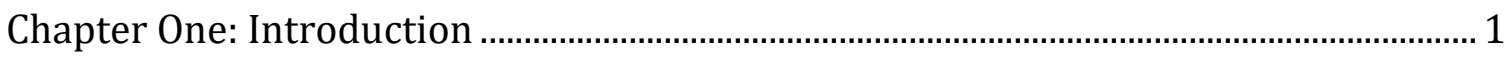

Chapter Two: "Uncrowded Quietude,” A Brief History of American Cemeteries ........15

Chapter Three: "Charm the Senses and Lighten the Grief of the Living," Colonization, Memory, and Secret Societies in Salem, Oregon ................................................................28

Chapter Four: "Procuring a Place More Appropriate," Urban Cemeteries in Portland,

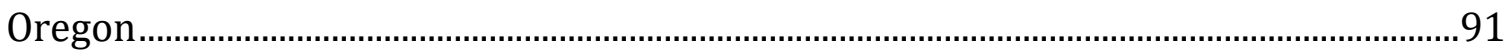

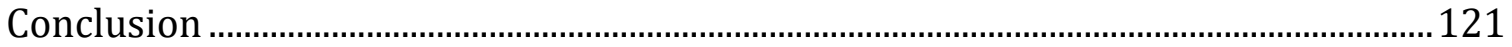

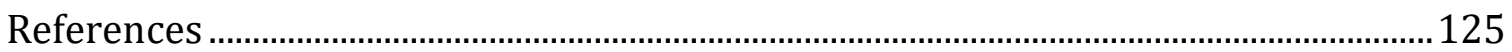


List of Figures

Figure 1: John Strutt, Viandanti sull'Appia Antica, 1858............................................... 16

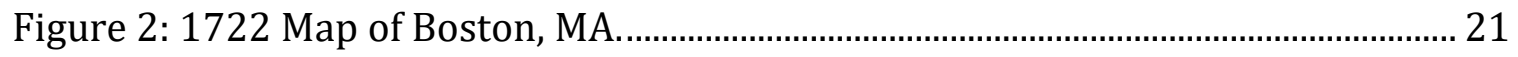

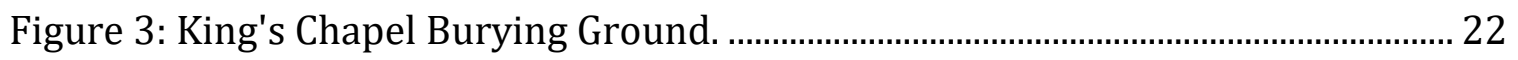

Figure 4: Photos of Mount Auburn Cemetery ................................................................ 25

Figure 5: Jason Lee in the US Capitol Rotunda ............................................................... 30

Figure 6: Unknown artist (likely Ammi Phillips), Anna Maria Pittman .......................... 36

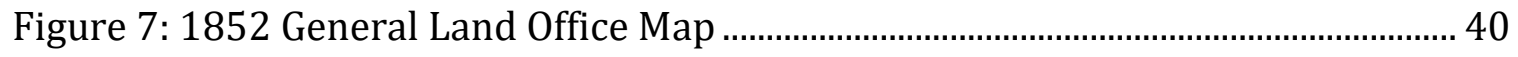

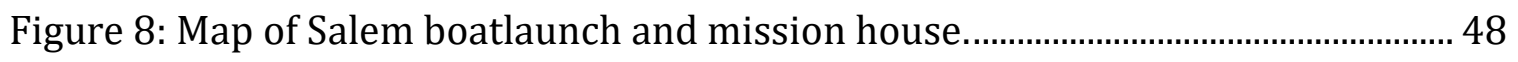

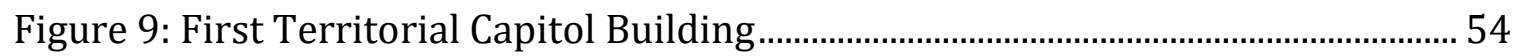

Figure 10: Odd Fellows Rural Cemetery ……….................................................................. 60

Figure 11: Detail from 1914 Plat Map of Odd Fellows Rural Cemetery .......................... 62

Figure 12: 1914 Plat Map of IOOF Rural Cemetery and Map of Green-Wood

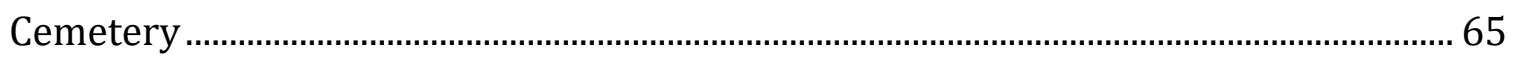

Figure 13: Bishop J. W. Hamilton at the Lee Mission Cemetery. ...................................... 73

Figure 14: Detail from c1900 map of Salem ...................................................................... 82

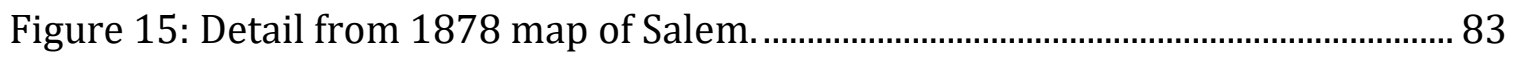

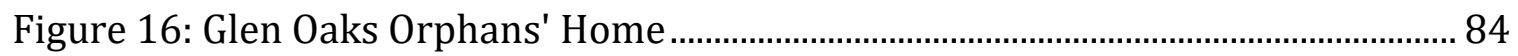

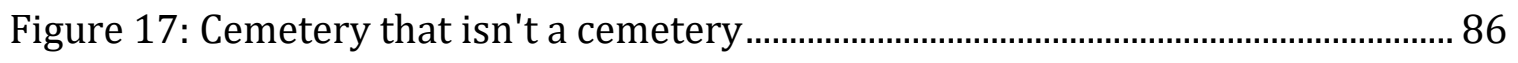

Figure 18: Map of Portland's first cemeteries .................................................................. 93

Figure 19: 1879 Birds-Eye Map of Portland............................................................................ 95

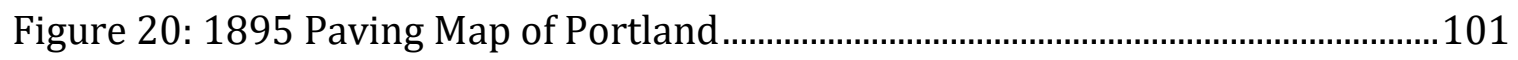

Figure 21: Riverview in 1887..........................................................................................115 
Humans bury not simply to achieve closure and effect a separation from the dead but also and above all to humanize the ground on which they build their worlds and found their histories.

Robert Pogue Harrison

Original grave marker of Anna Maria Pittman Lee:

\author{
BENEATH THIS SOD \\ the first ever broken in Oregon \\ for the reception of \\ white mother and child, \\ lie the remains \\ of \\ ANNA MARIA PITTMAN, \\ wife of \\ Rev. JASON LEE, \\ and her infant son. \\ She sailed from New York July 1836, \\ landed in OREGON June 1837, \\ was married July 16 , \\ and died \\ June 26, 1838, \\ aged 35 years, \\ in the full enjoyment of that love \\ which constrained her to leave all \\ for CHRIST and \\ heathen souls. \\ Lo, we have left all, \\ and \\ followed thee; \\ What shall we have therefore? \\ Mat 19
}


Chapter One: Introduction

In the 1930s, workmen were widening Portland's Burnside Street from the terminus of the Burnside Bridge over the Willamette River to the North Park Blocks. Suddenly, one workman's pick pierced the corner of a decaying wooden box. Upon opening, he discovered a skull. Though probably shocking for the workman, officials investigating the incident eventually discovered a reasonable explanation. Before the widening, sailors knew Burnside Street as a center for seedy attractions that vied for their coin in the quickly growing city. And well before both sailors and workmen walked near the intersections of Third and Burnside, early Portlanders meandered the wavy forest paths there, careful to avoid the gravestones and wooden markers which indicated the burial places of their friends and loved ones in Portland's first city cemetery.

Once the police officers assigned to the case determined that the skull and the wooden box were old enough not to warrant a murder investigation, they called in a historian to help crack the case. George Himes, the first curator at the Oregon Historical Society (who held his post there for over forty years) deduced that the location was not an Indian burial ground, nor a single grave, but Portland's first community cemetery. Thought to have been emptied some eighty years previously, this skeleton had been left behind when developers built over the unofficial 
cemetery. ${ }^{1}$ The officials in charge of investigating the Burnside Street skull never discovered who the remains belonged to, a reminder that while bones may remain, identity is much more tenuous.

Cemeteries are a mirror for the communities in which they are built. The first cemetery in Portland was chaotic and messy, reflecting the nature of many early Oregon cities. As a cemetery reflects a community, a burial reflects a person.

Whomever the Burnside Street skull belonged to was simply forgotten; no friends or family were in the area to remove their remains before developers built over the old cemetery. As this story suggests, cemeteries, and the memory of those buried within them, are indicators of identity, both for the community and the individual. In places like Portland and Salem, Oregon - significant cities in the story of western American resettlement - community and individual identity in spaces of death were especially shaped by the combined pressures of colonization, urbanization, and memory in the nineteenth and twentieth centuries. ${ }^{2}$ These pressures were visible in the

\footnotetext{
${ }^{1}$ This information comes from an undated newspaper article found in the Oregon Historical Society Research Library. Further research indicates that this widening of Burnside Street probably happened around 1931. See "Burnside Street History," Portland Bureau of Transportation, City of Portland, accessed March 4, 2018, https://www.portlandoregon.gov/transportation/article/295412 and "Many Pioneers Lie Under Third and Burnside Sts," undated article, Cemetery Vertical Research Files, Oregon Historical Society Research Library.

${ }^{2}$ Many have written about the colonization of America by European resettlers. For an important work on the theoretical framework of settler colonialism, see Michael Adas, "From Settler Colony to Global Hegemon: Integrating the Exceptionalism Narrative of the American Experience into World History," The American Historical Review 106, no. 5 (Dec 2001): 1692-1720. See also Frederick E. Hoxie, "Retrieving the Red Continent: settler colonialism and the history of American Indians in the US," Ethnic and Racial Studies 31, no. 6 (September 2008): 1153-1167; for an excellent critique of imperialist nostalgia which especially applies to the pioneer generation of the 1890s-1910s, read Renato Rosaldo, "Imperialist Nostalgia," in Culture \& Truth: The Remaking of Social Analysis (Boston: Beacon Press, 1989), 68-87. For an important work on the prominence imperial conquest plays in New Western History, see Patricia Nelson Limerick, The Legacy of Conquest: The Unbroken Past of the American West (New York: Norton and Co., 1987) and Kerwin Lee Klein, Frontiers of Historical
} 
development and physical layout of the cemetery as well as the way it, and those buried there, were cared for as time passed. This is a story about people and the spaces they occupy after death, both in our memories and in the physical space of our communities.

Euro-Americans coming from the East Coast chose Salem and Portland as some of the first cities to settle in the West, bringing their own death traditions with them along the way. Even though these cities developed around the same time and place, the cemeteries within them were wildly different. Where Salem had two, early, well-developed cemeteries created by religious or fraternal groups, Portland had a series of unsuccessful city cemeteries which eventually led to lawsuits, lost bodies, and disgruntled land owners. Why were these private groups more successful than the city government? Jason Lee and the other Methodist missionaries who founded Salem's first cemetery around 1840 had experienced the death of many of the Indigenous children who came to live with them at the earlier mission location about ten miles north of Salem. The Methodists knew cemetery space would be important in Salem as well and developed a dedicated space for the dead early in their efforts to create Salem's infrastructure. About fifteen years later,

\footnotetext{
Imagination: Narrating the European Conquest of Native America, 1890-1990 (Berkeley: University of California Press, 1999).The colonization of Oregon and the Pacific Northwest particularity is well covered by Gray H. Whaley, Oregon and the Collapse of Illahee: U.S. Empire and the Transformation of an Indigenous World, 1792-1859 (Chapel Hill: The University of North Carolina Press, 2010) and Melinda Marie Jetté, At the Hearth of the Crossed Races: A French-Indian Community in NineteenthCentury Oregon, 1812-1859 (Corvallis: University of Oregon Press, 2015). For a survey of the legal and political foundations of the Oregon Donation Land Claim Act which displaced Native people from their land and eventually led to the forced removal of Indigenous people to reservations, see "'The Nomadic Race to Which I Belong': Squatter Democracy and the Claiming of Oregon," Oregon Historical Quarterly 118, no. 3 (Fall 2017), p306-337, and Clifford E. Trafzer, "The Legacy of the Walla Wall Council, 1855," Oregon Historical Quarterly 106, no. 3 (Fall 2005), p. 389-411.
} 
the Salem chapter of the Independent Order of the Odd Fellows dedicated their time and resources to creating another cemetery for Salem's early citizens. Portland, though founded after Salem, grew rapidly under the influence of many early investors. No wealthy Portlanders considered cemeteries a good investment, at least initially, and only one private citizen stepped up the meet that need, though he too soon grew disillusioned with cemetery care. When the lack of cemetery space started to threaten Portland's long-term growth in the late nineteenth century, a group of capitalists founded a large, very modern cemetery as a non-profit to protect their urban investments. As Salem and Portland urbanized, so did their spaces of death.

Cemeteries are more than the necessary products of urbanization, they are built as places of mourning, reflection, and memory. Because of this intersection of memory and space, cemeteries are useful places to help tell a particular story. As Robert Pogue Harrison articulates, "humans bury not simply to achieve closure and effect a separation from the dead but also and above all to humanize the ground on which they build their worlds and found their histories." ${ }^{3}$ In the case of Salem, the reinterment of Jason Lee's remains nearly sixty years after his death in the place that he helped found as Oregon's capital was a turning point in both his personal story and the story of Oregon itself. The physical remains of Lee, along with politician Samuel R. Thurston, an integral figure in the Donation Land Claim Act of

${ }^{3}$ Robert Pogue Harrison, The Dominion of the Dead (Chicago and London: University of Chicago Press, 2003), xi. 
1850, were returned to Oregon's capital as a way to celebrate the influence their lives had on American control of the Oregon territory, and the subsequent success of the Americans who now lived there. These reinterments significantly influenced both Oregon politics and the historical narrative that many Oregonians hear about their state today.

The success of the Oregon colonization did not come without a significant cost - the lives of Indigenous people who called the "Oregon Country" home for thousands of years before Euro-American missionaries and settlers ever arrived. Cemeteries hold a unique place in this story. In the construction of curated burial grounds in the American West, resettlers were writing their own history in the physical landscape of their new homes. Historian Mathew Dennis explains that for arriving resettlers, the "ultimate imperial act would be the erasure of Native burial grounds, treatment of Indian remains not as relics but as trash, and erection in the Oregon landscape of new cemeteries that interred the expiring white pioneer generation, thus transforming Oregon into someone else's homeland."4 Jason Lee and his companions worked hard to reinter the remains of his first wife, Anna Maria Pittman Lee, and teacher Cyrus Shepard in Salem, but left behind the remains of the Indigenous children who died while under his care. Cemeteries, and the associated stories of those buried within them, were places where the narrative of resettlement

\footnotetext{
${ }^{4}$ Matthew Dennis, "Natives and Pioneers: Death and the Settling and Unsettling of Oregon," Oregon Historical Quarterly 115, no. 3 (Fall 2014): 286.
} 
could meld, change, and conform to one full of heroic tales of the pioneer generation, regardless - and oftentimes, in spite of - the real history.

These forces - memory, urbanization, and colonization - came together in the cemeteries of Salem and Portland to create unique spaces where EuroAmericans expressed their anxieties about death, city-living, and the development of the West Coast as a whole. By examining cemeteries and the burial of individuals in Oregon during the first years of resettlement, historians can learn more about the forces that contributed to the creation of these spaces and understand what these spaces mean for modern-day Oregonians. Death may be a constant across all human existence, but dying and burial changes with the time and place.

Death in Oregon and the Pacific Northwest specifically is unique and underresearched. While literary and non-professional histories about death in Oregon exist, with a few notable exceptions, the Pacific Northwest is strikingly absent from professional scholarly writing on death. Academic texts focus almost solely on pretwentieth century death in Europe, and for more modern American history, on the East Coast specifically. ${ }^{5}$ This is somewhat surprising because of the close association of death with the Oregon Trail in both popular culture ("you have died of dysentery") and general knowledge about the pioneer lifestyle. ${ }^{6}$ And while death on

${ }^{5}$ One of the most well-regarded texts about death in Western society is Philippe Aries' The Hour of Our Death (New York: Alfred A. Knopf, 1981). This massive tome explores over a thousand years of human attitude toward death, with a special emphasis on Europe. While there is a discussion about American death in this book, many scholars agree that it is the weakest section of the book and is better used for its treatment of death in Europe.

${ }^{6}$ I occasionally use the term "pioneer" to refer to those who came west beginning in the 1840s. The term itself is wrought with aspirations about what it meant to be one of these original "pioneers" but 
the trail itself has received some attention from scholars, there are few who have critically examined the spaces of death developed by those who survived the trip. ${ }^{7}$ Myth and legend about death in Oregon are easy to find; academic studies are few and far between.

One of the best resources about death in Oregon is a special issue of the Oregon Historical Quarterly titled "Death and the Settling and Unsettling of Oregon."8 It largely chronicles the fact that Euro-American pioneers settling the Oregon territory meant unsettling the generations of Native peoples who had called the land home for millennia. And with that unsettling came death in unprecedented waves for Native people, via both disease and outright genocide perpetrated by resettlers. However, while colonization had devastating impacts on Native people, it did not wipe them out entirely. The myth of the vanishing Indian is, in fact, a myth. Without first recognizing and understanding that truth, any scholarship about the Pacific Northwest fails its first residents. The role of cemeteries is an important aspect of this history and is evidence for how colonization manifests on the physical landscape. Oregon is a unique place to study the history of cemeteries since white resettlers chose the Willamette Valley as one of the first places to settle in the "New Frontier," and as they lived and settled here, they also died here.

\footnotetext{
sometimes proves to be a convenient shorthand way to describe this group of people. See Dennis, "Natives and Pioneers," 287 for more discussion on the use of this word. The "you have died of dysentery" reference is from the popular children's computer game called Oregon Trail.

${ }^{7}$ See Andrea Binder, "Deep is the grave, and silent:" Death and Mourning on the Oregon-California Trail, (master's thesis, University of Wyoming, 2011).

8 Oregon Historical Quarterly Special Issue, "Death and the Settling and Unsettling of Oregon," Oregon Historical Quarterly, 115, no. 5 (Fall 2014).
} 
The study of cemeteries as an academic mode of inquiry is relatively new. Historian Richard E. Meyer points out that it was not until 1927 that the first indepth study of American grave markers appeared. Further, it was not until the 1970s and 80s that there would be any depth of literature on the topic. ${ }^{9}$ As a newer field of study, it makes sense that there is not a large body of text about cemeteries in the Pacific Northwest. "Images of Logging on Contemporary Pacific Northwest Gravemarkers," a chapter written by Meyer, is one of the only academic texts about Oregon graveyards specifically.

Oregon cemeteries even escape the notice of texts that focus specifically on resettler spaces of death. Pioneer Cemeteries: Sculpture Gardens of the Old West, an especially promising title, does not mention Oregon or Washington. ${ }^{10}$ The author defines her area of interest as the Rocky Mountain West - Colorado, Utah, Wyoming, Idaho, and Montana. She cites changing burial influences as the reason not to extend her study into Canada or south of Colorado but there is no discussion of why she does not extend that line west to the coast. Many of the trends and patterns the author notes in their book equally apply to burials in Oregon, especially Eastern Oregon. Is the only difference that the Rocky Mountain West did not have early, large cities like Salem, Portland, and then later, Seattle? While this book is a valuable critical study of cemeteries near the Rocky Mountains, there is still a hole in death scholarship about the Pacific Northwest.

\footnotetext{
${ }_{9}^{9}$ Richard E. Meyer, ed., Cemeteries and Grave Markers: Voices of American Culture (Ann Arbor: UMI Research Press, 1989), 2-3.

${ }^{10}$ Annette Stott, Pioneer Cemeteries: Sculpture Gardens of the Old West (Lincoln: University of Nebraska Press, 2008).
} 
While there is a dearth of academic work on cemeteries and death in the Pacific Northwest, there is no shortage of tour-guides, local histories, and locally published works about Oregon burials. One of the most impressive feats is a guide book called the Oregon Burial Site Guide, a massive tome that contains driving directions to every recorded burial place in Oregon. ${ }^{11}$ Compiled over the span of decades, this book represents a massive commitment to preserving Oregon's burial history. There are others who have compiled books on Oregon cemeteries as well. Johan Mathiesen, an Oregon photographer and amateur historian, has published several of these guides featuring his photography and favorite inscriptions. ${ }^{12}$ The Lone Fir Cemetery, one of the oldest and most iconic cemeteries in Portland, is featured in many art- and travel-oriented books. It has even inspired a musical album and a documentary. ${ }^{13}$ Clearly, cemeteries are interesting to the general public. Oregon cemeteries should receive academic attention as well.

Expanding the scope to the national history of cemeteries provides important context and a baseline for comparison, as well as a much larger pool of academic work to draw upon. One of the most complete studies on the history of American cemeteries is The Last Great Necessity: Cemeteries in American History by historian

\footnotetext{
${ }^{11}$ Dean H. Byrd, compiler, Stanley R. Clarke and Janice M. Healy, co-compilers, Oregon Burial Site Guide (Portland: Binford and Mort, 2001).

${ }^{12}$ See Johan Mathiesen, Mad as the Mist and Snow: Exploring Oregon through its Cemeteries (Ashland, Or: Ashland Creek Press, 2011) and Hey Darlin': Epitaphs from the Oregon Territory (Portland, Or: DeadManTalking, 2012).

${ }^{13}$ See Johan Mathiesen, Lone Fir: The Cemetery: A Guide and History (Portland: DeadManTalking, 2012); Chris Ashby, Lone Fir Cemetery (Portland, Or: Abandoned Bike, 2011); Matt Sheehy, Jesse Emerson, et al., "Dearly Departed: True Lies in Song Unearthed from Lone Fir - A Benefit for Lone Fir Cemetery," Audio CD, K Wheel Records, 2008; Come Together Home, directed by Ivy Lin (Portland, Oregon, self published, 2009).
} 
David Charles Sloane. ${ }^{14}$ Tracing cemeteries from humble beginnings near churches in colonial America to the highly curated "memorial park" made most famous by the Forest Lawn Cemetery in Glendale, California, Sloane outlines how changing social attitudes towards the ethical limits of capitalism helped change the way cemeteries functioned and looked. However, the composition and type of cemeteries created in the Pacific Northwest during the nineteenth century do not match up exactly with similar development on the East Coast. Investigating these differences allows for a better understanding of how Western cemeteries developed in a dissimilar way than those on the East Coast.

As Sloane shows that evolving concepts of capitalism had effects on cemetery development, Aaron Sachs, in his book Arcadian America: The Death and Life of an Environmental Tradition, details the connections between environmentalism and death culture. This intersection began the rural cemetery tradition, most prominently in the 1830-40s. ${ }^{15}$ Mount Auburn in Boston, Massachusetts was the first cemetery in America where its creators valued the natural landscape as a place for reflection and a natural complement to the cycle of life and death. Largely a response to increased urbanization and industrialization in Boston, Mount Auburn came to represent an environmental tradition that recognized the importance of a connection to nature for all citizens, regardless of wealth or social status. Practically, it brought the cemetery to the edge of the city, solving many health and cleanliness

\footnotetext{
${ }^{14}$ David Charles Sloane, The Last Great Necessity: Cemeteries in American History (Baltimore: The Johns Hopkins University Press, 1991).

${ }^{15}$ Aaron Sachs, Arcadian America: The Death and Life of an Environmental Tradition (New Haven: Yale University Press, 2013).
} 
problems that had plagued American cities for decades. The trend caught on and for many years after, almost all new cemeteries across the nation were built in the "rural" style. Sachs is most successful in his discussion of how cemeteries changed the development of cities and prioritization of green space. The success of rural cemeteries is largely credited with inspiring the creation of city parks made specifically for recreation. In Oregon, as it was considered "wild" already, this trend translated into an odd mix of "rural" cemetery style and the more formal park-like setting of later cemeteries.

The study of cemeteries also requires inquiry into death and changing conceptions of dying in America. One of the most well-recognized texts on this subject is Drew Gilpin Faust's This Republic of Suffering: Death and the American Civil War. ${ }^{16}$ Faust's bestseller documents the change in American conceptions of dying, killing, and burying (and more) in the face of the proportionally astronomical number of deaths that occurred during the Civil War. During the mid-nineteenth century, Americans were largely concerned with a "good death" - a concept paralleled by the popularity of the rural cemetery movement. One should die peacefully, all accounts with God settled, and be buried in a beautiful place. However, the monstrous conditions of death during the Civil War represented the absolute opposite of a "good death."17 In addition, "loss became commonplace: death

\footnotetext{
${ }^{16}$ Drew Gilpin Faust, This Republic of Suffering: Death and the American Civil War (New York: Alfred A. Knopf, 2008).

${ }^{17}$ Faust, This Republic of Suffering, 6-9.
} 
was no longer encountered individually, death's threat, its proximity and its actuality became the most widely shared of the war's experiences." 18 The result was that many people had to settle for lower standards of care for the deceased friend and family, especially since many died far from any family or friends who could care for the body before it started to decompose. Embalming, invented during the Civil War, had a large impact on death culture in America, but really rose to prominence in the 1930s-1980s; only recently in our history has it become socially acceptable for someone to refrain from embalming before burial. The Civil War, which took place from 1861-1865, had a far less immediate effect on Americans who were busy colonizing the West Coast. While these changes did come, they made their way West slowly, and death and dying in the Willamette Valley was different than on the East Coast.

In addition to the history of death and cemeteries, the memory of the those buried within the cemetery also shapes community identity. Historian Michael Kammen offers an excellent overview of the history of reburials (or reinterments) in his text Digging Up the Dead: A History of Notable American Reburials. ${ }^{19}$ Kammen details that reburials happened across America in the face of changing ideals about proper burial after death. He also examines the effort that many went through to make sure prominent figures from the Revolutionary or Civil Wars were remembered at their place of burial many generations later. The body of Jefferson

\footnotetext{
18 Faust, This Republic of Suffering, xiii.

${ }^{19}$ Michael Kammen, Digging Up the Dead: A History of Notable American Reburials (Chicago: University of Chicago Press, 2010).
} 
Davis, the president of the Confederate States of America from 1861 to until the end of the Civil War in 1865 , is a prime example of the anxiety people at the end of the twentieth-century felt about the "proper" memorial for famous figures. Davis' remains became tied up in ideas about confederate pride despite the South losing the war. In the chapter titled “Disinterred by Devotion: Religion, Race, and Spiritual Repose," Kammen touches on the famous missionary stories of the Whitmans and the Lee Mission Party. The treatment of Lee is a good summary on this history of his reburial, but at only a few pages long, misses some of the nuance surrounding Lee's reputation just after the dissolution of the Willamette Mission. This study serves to complete this story and underscore the important connections between colonization and reburial in the West.

Another work which emphasizes the political implications of human remains is The Political Lives of Dead Bodies: Reburial and Postsocial Change by Katherine Verdery. ${ }^{20}$ Though this book focuses solely on Eastern Europe in the years after 1989, the narrative provides an informative parallel to the earlier reburials of Samuel R. Thurston and Jason Lee in Salem. Verdery argues that "authority always has a 'sacred' component," and the reburial of dead bodies is way for authority (government, religion, etc.) to access that sacred component. ${ }^{21}$ In addition, her text makes the point that reburial helps shape the "identities produced in [the] nation

\footnotetext{
${ }^{20}$ Katherine Verdery, The Political Lives of Dead Bodies: Reburial and Postsocial Change (New York: Columbia University Press, 1999).

${ }^{21}$ Verdery, Political Lives of Dead Bodies, 37.
} 
building processes" and that worship of founding figures is a form of nationalism. Reburial is a way to manually create a national genealogy; proper reburial of ancestors includes revering (some of) them "as cultural treasures."22 This anthropological frame guides my work in considering the political lives of the remains of Lee and Thurston in a different time and alternate place.

Together, this body of literature offers a wider context for the history of cemeteries in America. Cemeteries in the Oregon territory are different in many ways than cemeteries on the other side of the continent. Some of this has to do with the timing of Western resettlement and changes in cemetery practice - the rural cemetery movement happened just before concentrated white settlement on the West Coast - but some of these differences arise because of the way colonization manifested on the physical landscape. Death in the Willamette Valley is different than patterns found and studied in other parts of the country. This study asks what those differences are and what they can tell us about the intersections of death, memory, space, and colonization.

22 Verdery, Political Lives of Dead Bodies, 41. 
Chapter Two: “Uncrowded Quietude,” A Brief History of American Cemeteries

Cemeteries are a relatively modern phenomenon. Derived from the Greek word koimeterion, a place for sleeping, they are literally a final resting place. Despite their ancient connotation, cemeteries as we know them were largely imagined during the nineteenth century. Before the cemetery movement in 1800s, burial places were simple and oftentimes unpleasant. In contrast, a cemetery is a structured and pleasant curation of the dead. It was a pointed effort to make the burial space lovely and meaningful. As the appeal of a well-tended burial place grew, so did an interest in investing in them. The journey from "burying ground" to "cemetery" is a tale of colonization, urbanization, and commodification. A brief history of this journey is helpful for understanding how cemeteries in the Pacific Northwest do and do not fit into the general timeline of death culture in America. Most European settlers who arrived on the Atlantic coast during the seventeenth century expected burial upon their death. Burial has long been a form of body disposal, with intentional burials dating back to 100,000 years ago. ${ }^{23}$ However, burial is just one of the many options humans have to care for the dead. The Romans, for an ancient example, lined their roadways with cremated dead in elaborate memorials, so that passersby might read their names aloud and thus a

\footnotetext{
${ }^{23}$ Archaeologists found the arranged remains of a mother and child, surrounded by pieces of red ochre, in a cave at Qafzeh, Israel in 1933. See Smithsonian, "Qafzeh: Oldest Intentional Burial," What Does it Mean to be Human?, Smithsonian Institute, National Museum of Natural History, April 1, 2016, accessed February 27, 2018, http://humanorigins.si.edu/evidence/behavior/burial/qafzeh-oldestintentional-burial.
} 


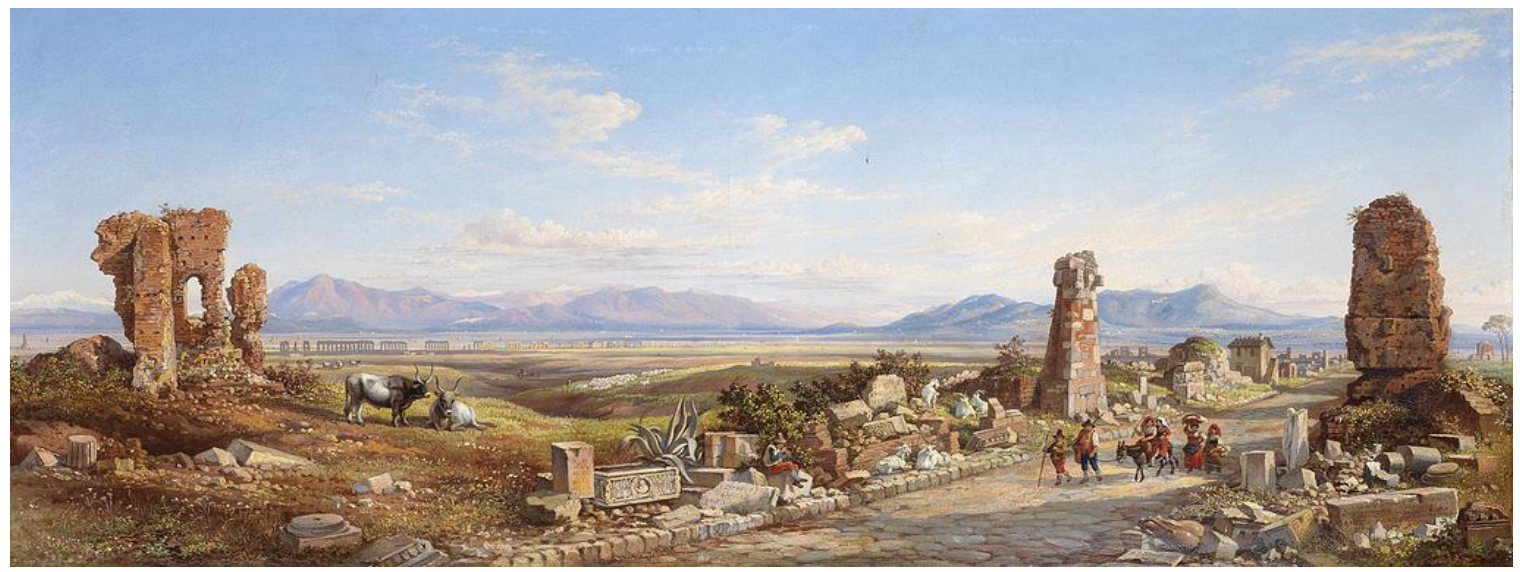

Figure 1: This 1858 painting by Arthur Strutt shows the Italian countryside with the Via Appia in the foreground. Notice the dilapidated monuments and columbaria along the roadway. John Strutt, Viandanti sull'Appia Antica, 1858, Wikimedia Commons, Public Domain.

person could experience a kind of afterlife. If not in a tomb along the Appian Way, a

Roman might find their cremated remains in one of the many columbaria available, one niche in a room of hundreds of urns. Burial, associated with even older ancient customs, never fell entirely out of favor; many of Rome's poor were buried in what amounted to "potter's fields" even when the height of fashion was cremation during the first years of the Roman Empire. ${ }^{24}$ If Romans, whose culture is often considered one of the foundations of modern European and American culture, preferred cremation, how did burial become the preferred funerary custom? The answer lies in the spread of Christian culture across the globe and its interpretation of resurrection. The following will chronicle a summary of these changes. For a more

\footnotetext{
${ }^{24}$ Harold Whetstone Johnston, revised by Mary Johnston, The Private Life of Romans (Rome: Scott, Foresman and Company, 1903, revised 1932), 14:465-466, accessed March 6, 2018, http://www.forumromanum.org/life/johnston_14.html\#465.
} 
complete history on changing burial practices in Europe, see The Hour of Our Death by Philippe Aries (1981).

Generally, Judaic religious tradition embraced burial over other forms of disposal; later Christians were especially concerned with preserving the body as best as possible for resurrection. Because of this concern, burial became the de facto method of disposal in almost every country with Christian influence. Some ecclesiastical writers did not see burial as a necessity, as surely an omniscient God was capable of restoring bodies in any form. However, more influential ecclesiastics rejected these arguments, and burial became the only acceptable form of body disposal. ${ }^{25}$ In largely Christian Europe, and especially during the middle ages, death usually meant burial in a church graveyard or mass burial pit. Because of lack of space in churchyards, remains were later disinterred and placed in a charnel house so that the burial space could be occupied by another body. ${ }^{26}$ As Europeans began colonies in America, these practices translated into many of the same traditions, though some aspects changed significantly.

The burying traditions of colonial Americans were largely different from indigenous funerary practices, which varied from coast to coast and from tribe to tribe, and these differences contributed to the binary classification of Indigenous people as "uncivilized" when compared to the "civilized" white colonizer. The range of funerary customs of Indigenous peoples across the American continent is wide;

\footnotetext{
25 Sloane, Last Great Necessity, 17-18.

${ }^{26}$ See Phillippe Aires, trans. Helen Weaver, The Hour of our Death (New York: Alfred A. Knope, 1981) for a in depth discussion of trends in death culture in Europe and western culture.
} 
for example, burial was a common practice among the Athabascan-speaking people of New Mexico and Arizona. Traditionally in the Navajo tribe, a body would be immediately buried or left in the hogan (home) which was subsequently abandoned. There was no period of mourning for people who died of old age. ${ }^{27}$ In Oregon, some Kalapuya bands practiced mound burial where many individuals were interred in a large mound with ritualist items. ${ }^{28}$ Burial was not the only way that Native people disposed of their dead. The Chinook people of the Columbia River laid their dead in canoes, open to the air. ${ }^{29}$ In 1880 , the Smithsonian published the "Introduction to the Study of Mortuary Customs Among the North American Indian" which documented other practices like cremation, embalming, aerial sepulture, and water burial. ${ }^{30}$

Indigenous funerary practices were subject to both criticism and exotic fascination and the dismissal of Indigenous remains contributed to the dehumanization of Native people across the country. Many death rituals in Native communities have changed greatly in years since colonial resettlement began and many traditional places of interment have been damaged or destroyed. However, in

\footnotetext{
27 E.B. Eiselein, writing as Ojibwa, "Death in Pueblo and Athabascan Cultures," Native American Netroots, March 18, 2016, http://nativeamericannetroots.net/diary/1467 (accessed March 6, 2018). ${ }^{28}$ Unfortunately, these mounds were the subject of intense and racially charged archaeological interest during the twentieth century and many have been destroyed by both professional and amateur archeologists. See David Lewis, "Mounds of the Tualatin-Yamhill Kalapuyan Area," NDNHISTORYRESEACH: Journal of Critical and Indigenous Anthropology and History, August 1, 2017, accessed July 6, 2018, https://ndnhistoryresearch.com/2017/08/01/mounds-of-the-tualatinyamhill-kalapuyan-area.

29 "Disease and Burial Customs," trailtribes.org: traditional and contemporary native culture, no date, accessed September 15, 2018, https://trailtribes.org/fortclatsop/disease-and-burial-customs.htm. ${ }^{30}$ H. C. Yarrow, Introduction to the Study of Mortuary Customs Among the North American Indians (Washington, D.C.: Smithsonian Institution, Bureau of American Ethnology, 1880), accessed online via Archive.org, https://archive.org/details/introductiontost00yarr.
} 
1990, Native people gained important legal protections for their ancestors' remains through laws like the Native American Grave Protection and Repatriation Act (NAGPRA, 1990). This law is one example of how Native people have survived the disease and decimation associated with white settlement. Christians often defined themselves as "civilized" because of the differences between Indigenous and settler society. Death culture was yet another way in which Christian colonizers and the missionaries sent to convert Native people across the country during the eighteenth and nineteenth centuries found Indigenous people in direct opposition to a Christian god. Christian burial culture and cemeteries in American society were one way to signal "civilization" and Euro-American ownership of a place. ${ }^{31}$

For Euro-American colonies and later post-Revolution communities, burial practices changed to better meet the needs of the growing towns and cities. One of the most significant changes was the secularization of the cemetery in more rural areas of America. Many families buried their dead on their own privately-owned ground, in family-centric burial places. British author and social commentator Harriet Martineau reflected on a visit she took to the East Coast in the 1830s:

\footnotetext{
${ }^{31}$ For a detailed timeline of injustices perpetrated against Indigenous people through a framework of colonization and collection, as well as the story of Native resistance against this narrative, see Kathleen S. Fine-Dare, Grave Injustice: The American Indian Repatriation Movement and NAGPRA (Lincoln: University of Nebraska Press, 2002). Others excellent recounting of Native resistance to the culture of collection and the racism entrenched in history and museum practices are Karen Coody Cooper, Spirited Encounters: American Indians Protest Museum Policies and Practices (Lanham: Altamira Press, 2008) and Amy Lonetree, Decolonizing Museums: Representing Native America in National and Tribal Museums (Chapel Hill: University of North Carolina Press, 2012). For more information about death practices as a measurement of "civilization," see Gray H. Whaley, "'Trophies' for God: Native Mortality, Racial Ideology, and the Methodist Mission of Lower Oregon, 1834-1844," Oregon Historical Quarterly 107, no. 1 (April 2006): 6-35.
} 
"wherever there is a solitary dwelling there is a domestic burying-place, generally fenced with neat white palings, and deliberately kept, however full the settler's hands may be, and whatever may be the aspect of the abode of the living." 32 In this way, agrarian Americans diverged significantly from European tradition of churchyard burial. These differences are attributed to several factors, though one of the most significant was the isolation felt by many early settlers in American country. As social commentator Susan Cooper noted in 1851, many people were "separated by distance and bad roads from any place of worship." 33 As the population increased in some of these rural towns, some family burying places started to accommodate burials from the whole community. Historian David Sloane argues that because of the dearth of religious clergymen, burial traditions became more about the community's continual survival despite the loss of the individual, and religious connotations fell away. ${ }^{34}$ As these communities grew larger in population, so did the cemetery, and some of the same problems which faced the more traditional churchyard burial started to plague these secular burials grounds as well.

During the same time period, Americans in denser settlements did not have the option to bury family on private ground and still utilized the more traditional churchyard burial. Predictably, space quickly became a problem. As early as the 1650s, when Boston's oldest burial ground, King's Chapel Burying Ground became

\footnotetext{
${ }^{32}$ Harriet Martineau, Retrospect of Western Travel, 2 vols. (London and New York, 1838), 2:228 as quoted in Sloane, The Last Great Necessity, 14.

${ }^{33}$ Susan Cooper, Rural Hours (New York, 1851), 280 as quoted in Sloane, Last Great Necessity, 17.

${ }^{34}$ Sloane, Last Great Necessity, 17.
} 
too crowded, the city government decided that "the old burying place shall be wholly deserted for some convenient season, and the new places appointed for burial only made use of."35 On this 1722 map of Boston, Massachusetts, there is a small piece of land just east of the Boston Common labeled "burying place," which is now known as the Granary Burying Grounds, one of the places chosen to reduce the crowding at King's Chapel. ${ }^{36}$ Another famous example of churchyard burial

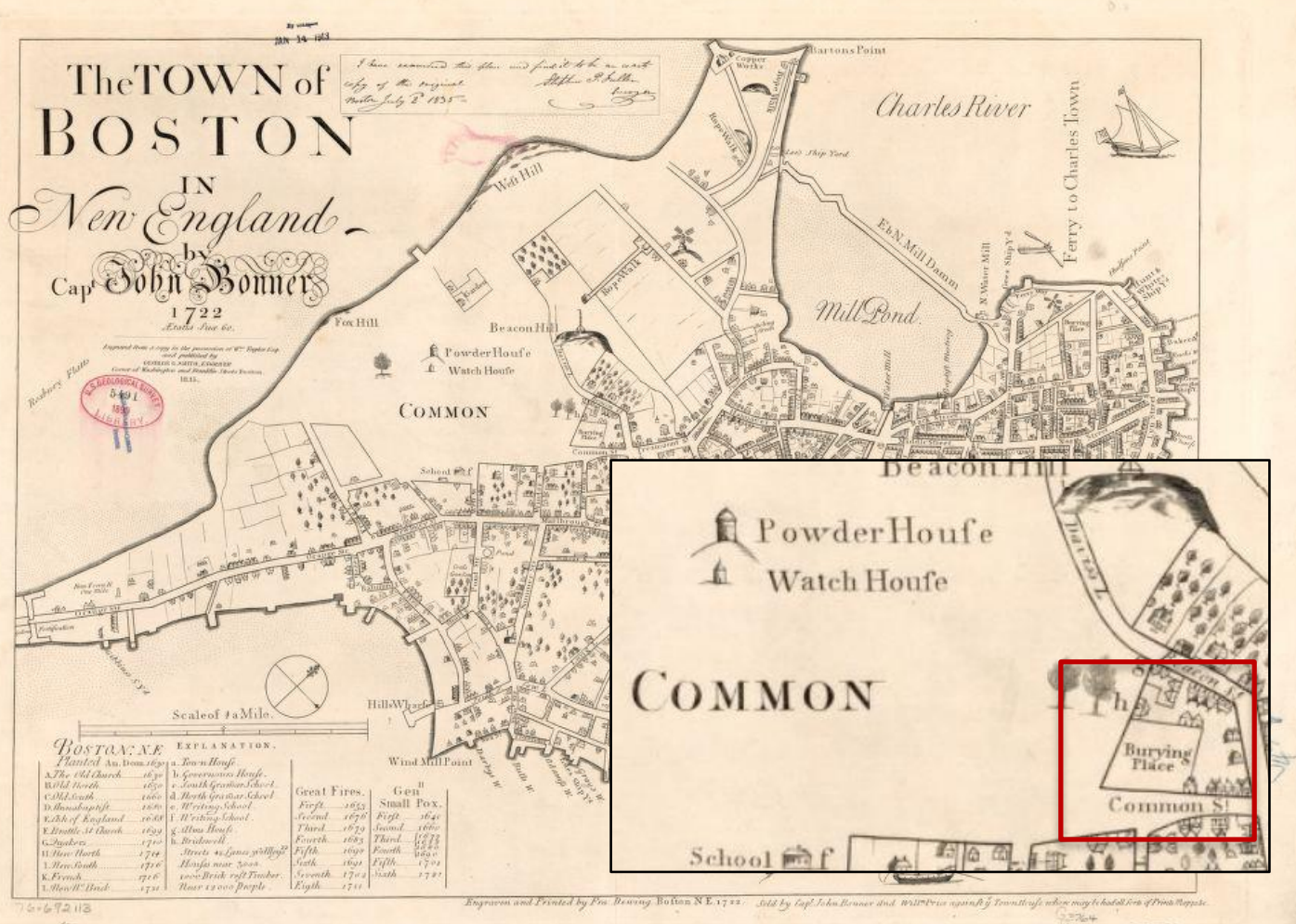

Figure 2: The detail on this 1722 map of Boston shows the "burying place" set aside in the Boston Common. Map courtesy Library of Congress.

\footnotetext{
35 Boston Town Records, entry dated November 5, 1660 in Records Relating to the Early History of Boston, vol. 2 (1877), 158 as quoted in Caitlin Galante-DeAngelis Hopkins, "The Shadow of Change: Politics and Memory in New England's Historic Burying Grounds, 1630-1776" (PhD diss., Harvard University, 2014), 30, accessed September 16, 2018, ProQuest Dissertations and Theses.

${ }_{36}$ Michael Rawson, Eden on the Charles: The Making of Boston (Cambridge: Harvard University 2010), 59-60. For map see John Bonner, Francis Dewing, George Girdler Smith, William Price, and Stephen P Fuller, "The town of Boston in New England," (Boston: George G. Smith, 1835), Map, accessed via Library of Congress October 3, 2018, https://www.loc.gov/item/76692113/.
} 


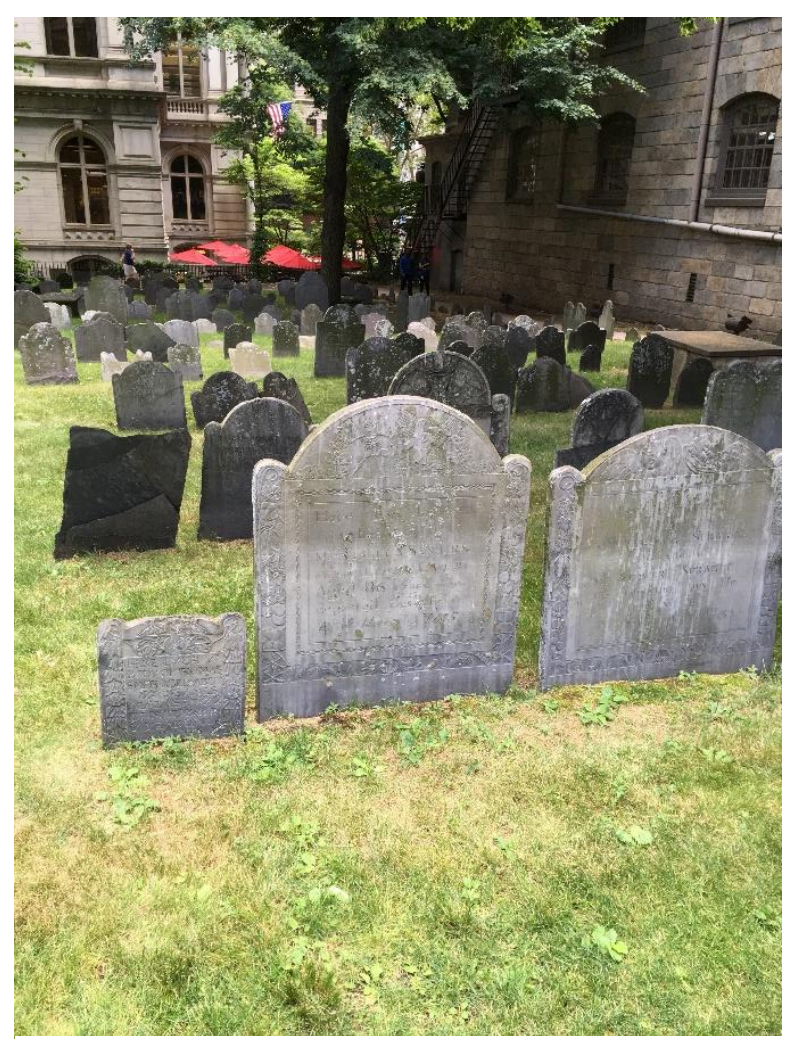

Figure 3: King's Chapel Burying Ground, 2018, author's collection.

crowding is Trinity Church and its adjacent cemetery in Lower Manhattan, New York City. Granted a charter by Royal Governor Benjamin Fletcher of New York in 1697, a group of Anglican worshipers erected a church to serve the community of New York City, which was home to about 5,000 people in $1698 .{ }^{37}$ Contemporaries estimated that by 1800 , over 100,000 New Yorkers were buried in the under twoacre cemetery. This large number of burials over a relatively small space necessitated reusing the burial spaces. In fact, the level of the churchyard as a whole rose by several feet from the burials underneath and by the nineteenth century, "it

${ }^{37}$ Ira Rosenwaike, Population History of New York City (Syracuse: Syracuse University Press, 1972), 7. 
sat well above the surrounding streets." 38 Other examples include St. Philip's

churchyard in Charleston where, according to an 1859 report, around 10,000 bodies were occupying space that was intended for two-thousand graves. ${ }^{39}$

By the beginning of the nineteenth century, church and community burial practices were proving wholly unsustainable and the pressure for more burial space, along with social movements that arose around the same time, merged to create a wholly new kind of death space - the cemetery. As the U.S. population increased, urban burying grounds were hitting a critical mass of bodies. There was not enough room for more remains and "corpses quickly started spilling out of official enclosures." The organized burying grounds of the Puritans became a jumble of markers, resulting in town centers where "odors of putrescence competed with the sour stink of sewage and factory fumes." 40 At a time when smells, referred to a miasmas, were considered a health risk, an idea to take burials out of the city soon arose. ${ }^{41}$ These ideas were not only inspired by the practical, if unpleasant, realities of decomposing bodies but also the broad social reforms that captivated many Americans during the Second Great Awakening. The rise of Transcendentalism, Abolitionism, environmentalism, anti-capitalism, and the women's movement all

\footnotetext{
${ }^{38}$ Sloane, Last Great Necessity, 19-20.

39 "Reports of the Committee of the City Council of Charleston, upon Interments within the City and the Memorial from Churches and Citizens," (Charleston, 1859), 22-23 as referenced in Sloane, Last Great Necessity, 20.

${ }^{40}$ Aaron Sachs, Arcadian America: The Death and Life of an Environmental Tradition (New Haven: Yale University Press, 2013), 22.

${ }^{41}$ See Stephen Halliday, "Death and Miasma in Victorian London: an obstinate belief," British Medical Journal 323, no. 7327 (December 2001), 1469-71 for a discussion on the medical understandings of miasmas during the nineteenth century.
} 
helped to shape Americans beliefs about "good death." 42 What arose from these intersections was an effort to take the cemetery out of the city and into the country, a truly "rural cemetery."

The rural cemetery tradition in America started in 1831 with Mount Auburn Cemetery, located outside of Boston, twenty-eight years before Oregon would become a state. Guided by the principle of "repose," or the idea that death was like a peaceful, natural sleep, Mount Auburn was one of the first true "cemeteries" in America - a purposeful, thoughtful attempt at interpreting the death and remembrance of loved ones. Founded by Gen. Henry A. S. Dearborn and his associate Dr. Jacob Bigelow, both members of the Massachusetts Horticultural Society, the focus on a natural landscape as a background for the cemetery was in part a response to the rapid industrialization of Boston. ${ }^{43}$ Mount Auburn provided the opportunity to be humbled, to be absorbed in "the depths of nature" and, as described by an 1839 visitor's guide, the "uncrowded quietude and primitive simplicity - this glistening turf, - these cool, sweet-winding avenues and paths this green, fresh beauty of the woods." 44 Rural cemeteries caught on with other Americans almost immediately, and by the 1850s, almost every large city had a cemetery modeled on Mt. Auburn. Not only did they solve the problem of overcrowding, they were also beautiful and peaceful places to enjoy nature, even for

\footnotetext{
42 Sachs, Arcadian America, 22.

43 Sachs, Arcadian America, 22, 30.

44 The Picturesque Pocket Companion, and Visitor's Guide, through Mount Auburn (Boston: Otis, Broaders \&Co., 1839), 208, available via Archive.org, accessed November 3, 2018, https://archive.org/details/picturesquepocke00mounrich/page/208.
} 
those who lived in the center of a large city. Cemeteries became an escape for those feeling overwhelmed by the fast advances of industrialization. The draw of public greenspace combined with the practical appeal of moving decomposing bodies to the edge of town helped the rural cemetery migrate to more agricultural locations in the south as well. 45

The rural cemetery, inspired by an instinct to reconnect human death to the natural cycles of nature, was quickly changed by the influences of capitalism. Markers, which used to complement the natural landscape, were becoming grand testaments to the wealth of their creators. The rural cemetery slowly transitioned to something that more closely resembled a highly structured park with large, ostentatious mausoleums and elaborate headstones. Spring Grove Cemetery in Cincinnati, and its manager Adolph Strauch, was one of the first cemeteries which
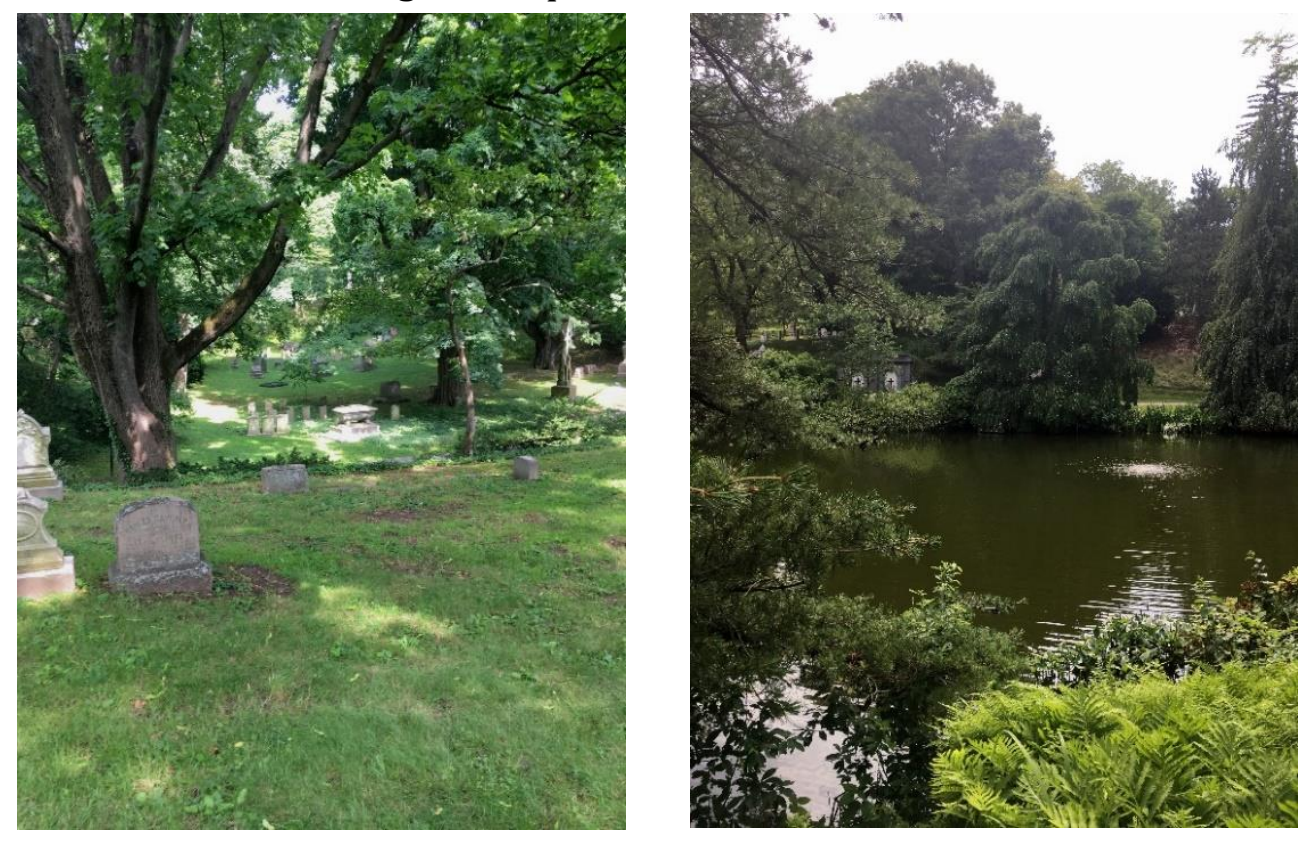

Figure 4: Photos of Mount Auburn Cemetery, 2018, author's collection.

\footnotetext{
45 The rural cemetery and places like the Boston Common are credited with inspiring city-parks. See especially Rawson, Eden on the Charles, for this discussion.
} 
abandoned the rural cemetery concept for more profitable "park lawn" type cemetery. In 1855, ten years after Spring Grove was established as a rural cemetery, Strauch redesigned it to better facilitate the sale of lots with a more structured layout. This trend proved very lucrative and many cemeteries followed suit. 46

In addition to the change in physical death spaces, Americans also started to change the way that they remembered the dead as well. While in early colonial America, inspired by the modest inclinations of Calvinism, people had favored a simple burial in a private place (oftentimes without a marker), by the midnineteenth century, as religious tradition softened to welcome more people, Americans developed a desire to commemorate and preserve burial places, especially those of prominent individuals. ${ }^{47}$ In the 1840 s, Bostonians developed a movement to honor the burial place of Revolutionary hero Sam Adams. However, because he had not received a personal monument in the Old Granary Burying Ground, no one knew exactly where to place the monument. ${ }^{48}$ Reburial became a secular way for the living to possess and memorialize the dead. As historian Michael Kammen articulates, reburial was about "possession and memorialization: matters of reputation, memory, sentiments concerning the most suitable venue, pride of ownership, plus the commercial development of privately owned cemeteries, and eventually even tourism." 49 Cemetery managers often competed for the remains of

\footnotetext{
46 Sloan, in The Last Great Necessity, dedicates an entire section of his book to the commercialization of rural cemeteries; see specifically pages 99-105.

47 Michael Kammen, Digging Up the Dead: A History of Notable American Reburials (Chicago:

University of Chicago Press, 2010), 17.

${ }^{48}$ Kammen, Digging up the Dead, 16.

49 Ibid, 20.
} 
prominent Revolutionary figures to attract more potential burials, and thus, more revenue.

As the rural cemetery and ideas about memorialization were developing on the East Coast, especially from 1830-1880, another large change was happening on the other side of the continent: the settlement of the Oregon Country by EuroAmerican colonists. These new resettlers brought Eastern American burial traditions west, including the rural cemetery. New spaces of death collided with efforts to colonize the West and created something unique. Partially because settlers began cemeteries in the West during this critical juncture in the theoretical design of cemeteries, they ended up occupying an odd conceptual place somewhere in between the "burying ground," rural cemetery, and the commercialized park cemetery. Even in these already rural places, the "rural" cemetery tradition proved its viability as a burial place in almost any setting. However, as explored in the next chapter, what might be considered a true "rural cemetery" on the East Coast was very different than what rural cemetery on the West Coast. 
Chapter Three: "Charm the Senses and Lighten the Grief of the Living," Colonization, Memory, and Secret Societies in Salem, Oregon

In 1860, about twenty years after Jason Lee first moved his Methodist mission to what is now known as Salem, Oregon, the editors of the Weekly Oregon Statesman published an article about the importance of selecting appropriate land for cemeteries in towns and cities all across Oregon: "respect to the dead is enjoined by the commonest dictates of humanity; and in all civilized communities, so sacred is held everything pertaining to the departed, that the public sentiment will not brook an indignity to the lifeless clay, or a wanton insult to the memory, even of one who in life failed to command esteem or respect." A spot "inviting to contemplation and repose" - a direct call to the rural cemetery styles of Mount Auburn in Boston and Greenwood Cemetery in New York - exemplified a desire to copy the death spaces of great cities around the world. The piece, possibly authored or co-written by wealthy owner/editor Asahel Bush, even calls out these places specifically:

It is not necessary to emulate the gay splendor of Pere la Chaise [sic], or the gloomy grandeur of Westminster, or the monumental pride of Greenwood; taste and skill, and the judicious selection and arrangement of trees and shrubs and flowers, will insure a beauty less grand but more grateful than that of those world-famed burial places, and which, if it does not sooth the slumbers of the dead, will charm the senses and lighten the grief of the living. 50

50 "Cemeteries," Weekly Oregon Statesman, May 22, 1860, p. 2. The Oregon Statesman was founded in 1850 by owner Samuel R. Thurston, with Asahel Bush as the editor. Bush became the owner after the death of Thurston in 1851. He continued as editor until he left the paper before the Civil War in 1863. Bush was a wealthy investor and was part of the group known as the "Salem Clique." His advocacy for cemetery space signals a desire for increased development in the state, endeavors that may well have been funded by one of his later investments, Ladd and Bush Bank, founded in Salem in 1869. See 
A rural-style cemetery outside the city limits was the kind of cemetery that great cities had, and according to Bush, Oregonians had better get planning.

In 1860, Salem was on its way to becoming one of the most developed cities in the West, especially considering that it already had two well-established cemeteries. ${ }^{51}$ The Independent Order of the Odd Fellows founded The Odd Fellows' Rural Cemetery in 1854 and Jason Lee's Methodist Mission had been using the cemetery they founded east of the city since their arrival in Salem in $1841 .{ }^{52}$ In Salem, cemetery space was essential to the story of the resettler. The Jason Lee and Odd Fellows cemeteries showcased Salem as a colonized, civilized city on the West Coast - worthy of the title of capital as well as dignified enough to house the remains of prominent Oregonians like Hon. Samuel R. Thurston. Years later, a group of Oregonians banded together to rehabilitate the Jason Lee Cemetery in a narrative arc that almost directly correlated with the evolution of Jason Lee's reputation, culminating in his reinterment in Salem almost sixty years after his death. The reburials of Thurston and Lee emphasized the positive aspects of colonization for Euro-Americans, while in contrast, the remains of some of those who did not fit the model of white, successful settler were simply forgotten or even lost. Despite the

\footnotetext{
Floyd J. McKay, "Oregon Statesman," Oregon Encyclopedia, last updated March 17, 2018, accessed September 16, 2018, https://oregonencyclopedia.org/articles/oregon statesman/\#.W57en-hKhPa and Barbara Mahoney, "Asahel Bush, 1824-1913," Oregon Encyclopedia, last updated March 17, 2018, accessed September 16, 2018, https://oregonencyclopedia.org/articles/bush asahel 18241913 /\#.W57hWOhKhPZ. ${ }^{51}$ Portland, in contrast, struggled to provide suitable burial space for its citizens until the $1880 \mathrm{~s}$. See Chapter Four.

52 The founding date of 1838 refers to the death of Anna Maria Pittman Lee, who died at the old Mission Bottom site and was later reinterred in the Jason Lee Memorial Cemetery, though that exact date is unclear.
} 
noble intentions of the above author, the remains of Native people who died while attending Jason Lee's Methodist school and patients at the Oregon State Insane Asylum did not receive the same level of respect or care that Lee or Thurston did. Investigating the history of cemeteries in Salem, as well as the memories of prominent people buried in them, reveals the anxieties that white settlers felt about their place in Oregon and their own futures in the face of agricultural decline and cultural change around the turn of the nineteenth century.

Jason Lee is now one of the most famous figures of Pacific Northwest history, but his legacy is much more complicated than what is espoused in the founding myths of the state. His statue is in the rotunda of the United States Capitol Building, as well as the grounds of the Oregon State Capitol Building, but his legacy as

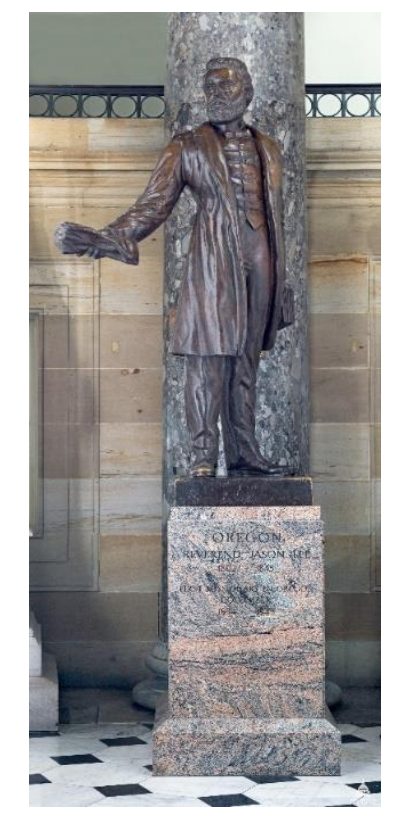

Figure 5: Jason Lee in the US Capitol Rotunda. Gifford MacGregor Proctor, Jason Lee, bronze, given by Oregon in 1953, National Sanctuary Hall, U.S. Capitol 
"conqueror" of the Oregon Country was not always a given. ${ }^{53}$ Contemporaries and early historians of the Oregon Country were critical of his motives and influence. It was not until many years later that some Oregonians worked to change the narrative from one of disdain or indifference to a celebratory accounting of his life and work in Salem and the American West Coast. These efforts culminated in the reinterment of Jason Lee's remains in the Jason Lee Cemetery in Salem, Oregon - the city which he founded and where he helped establish American control of the Oregon Country. To understand how important Jason Lee was to the pioneer story touted by Oregonians around the turn of the nineteenth century - and how different that story was from contemporary critiques of his work - a history of the Methodist mission and the development of its cemetery in Salem is essential background. When Jason Lee arrived in Oregon with his party of Methodist missionaries in 1834 , they found a land in flux, and not at all what they had expected to find. ${ }^{54}$ For decades, trappers had been reaping the benefits of complex trade networks between themselves and Indigenous Nations which supplied profitable furs to the rest of the world. Many of these trappers worked under John McLoughlin and for the monopoly of the British-controlled Hudson's Bay Company (HBC hereafter), which founded

\footnotetext{
${ }^{53}$ See Rev. A. Atwood, The Conquerors: Historical Sketches of the American Settlement of the Oregon Country, Embracing Facts in the Life and Work of Rev. Jason Lee, the Pioneer and Founder of American Institution on The Western Coast of North America (Boston, Cincinnati, Tacoma, Portland, New York, Chicago, Seattle, San Francisco: Jennings and Graham, 1907) for one of the most egregious examples of promotional literature published on Jason Lee in the decades after his death.

${ }^{54}$ See Gray H. Whaley, Oregon and Collapse of Illahee: U.S. Empire and the Transformation of an Indigenous World, 1792-1859 (Chapel Hill: The University of North Carolina Press, 2010) for an excellent history of the colonization of Oregon.
} 
Fort Vancouver in $1825 . .^{55}$ However, by the time the Methodists traveled west, the fur economy was destabilizing and HBC was searching for a "colonial economy" in the face of possible American expansion. ${ }^{56}$ As a consequence of this and earlier contact between Europeans and Indigenous people, diseases devastated the populations of Natives who called the land home. As malaria spread, social and economic structures that were well established under the fur trade began to collapse under demographic pressure. ${ }^{57}$ It was during this time that Lee and his party arrived to spread the word of God to the pagan "flatheads" of the Oregon Country, and what they expected to be the easy Christianization of Oregon turned into something much more complicated. 58

At the beginning of the mission period, Lee was well-regarded and liked by his party. John Kirkland, who traveled across the Rockies in a large group that included Jason and his brother, Daniel Lee, in 1834, described Jason Lee as "a great favorite with the men, deservedly so." 59 In Kirkland's description, the reasons why

\footnotetext{
${ }^{55}$ Fort Vancouver National Historic Site, “The Hudson's Bay Company's Fort Vancouver," National Park Service, https://www.nps.gov/fova/learn/historyculture/hbcfort1.htm (accessed May 13, 2018).

${ }^{56}$ Whaley, Oregon and the Collapse of Illahee, 99.

57 Whaley, Oregon and the Collapse of Illahee, 99.

${ }^{58}$ The Methodist Mission party originally intended to settle in the Rocky Mountains. In 1835, the Mission board decided to change the name of the mission from the "Flathead Mission" to the "Oregon Mission" because "the real Flathead Indians were few in number and had no settled habitations." See Robert J. Lowenberg, Equality on the Oregon Frontier: Jason Lee and the Methodist Mission, 1834-43 (Seattle and London: University of Washington Press, 1976) 85-86.

${ }^{59}$ John K. Townsend, Narrative of a Journey Across the Rocky Mountains, to the Columbia River, and A Visit to the Sandwich Islands, Chili, \&c. with A Scientific Appendix (Philadelphia: Henry Perkins, 1839), 228.
} 
Lee was initially chosen to lead the Oregon Mission are clear: Lee was an engaging preacher, "characterized by [a] mildness and affectionate manner."60

Despite this favorable start, once the missionaries arrived in Oregon, they faced a myriad of issues; one of the most pressing in their attempts to convert the Indigenous peoples of the Willamette Valley was the seeming necessary connection between Christianity and "civilization." 61 In the eyes of the missionaries, one could not necessarily be Christian unless one led a "civilized" life. ${ }^{62}$ Historians Gray Whaley and Robert J. Lowenberg detail the challenges that Lee and his company found in meeting the ideals of Methodist teachings while living in what was, for the missionaries, the harsh reality of the uncolonized West. With McLoughlin's help, the missionaries chose a site near Champoeg, close to the homes of French-Canadian extrappers who had begun families with nearby Native women. ${ }^{63}$ The location was referred to as "Mission Bottom" and was about eleven miles north of present-day Salem. By 1835, Mission Bottom included a farm and a school for "reclaiming these wandering savages, who are in a very degraded state, to the blessings of Christianity

\footnotetext{
${ }^{60}$ Ibid., 228-229.

${ }^{61}$ See Robert J. Lowenberg, Equality on the Oregon Frontier: Jason Lee and the Methodist Mission, 1834-43 (Seattle and London: University of Washington Press, 1976), especially Chapter 4, "Christianity or Civilization?" for a discussion on how the missionaries dealt with the seeming contradiction between conversion and civilization.

62 In this context, "civilized" means living as the missionaries were used to, like Euro-Americans on the East Coast in the 1830s.

${ }^{63}$ In the beginning, the relationship between these groups of people was largely congenial. As the question of British or American and Protestant or Catholic control grew closer, these relations somewhat soured. See Melinda Marie Jetté, At the Heath of the Crossed Races: A French-Indian Community in Nineteenth-Century Oregon, 1812-1859 (Corvallis: Oregon State University Press, 2015), especially chapter three, "Methodist Missionaries and Community Relations."
} 
and civilized life."64 While Jason Lee and his company wanted to focus their work to teaching the bible, the realities of subsistence agriculture kept them, and the Native children at the school who did much of the manual labor, away from their studies. ${ }^{65}$ Lee dealt with the perceived connection between civilization and Christianity by slowly redefining the idea of what Christianization looked like in the West. Instead of the traditional missionary - a well-educated, single man - Lee requested that women, farmers, and other skilled individuals come to the Oregon Mission to serve as examples to Native people. Americanization and Christianization started to mean the same thing: "an exemplary Christian was, of course, an exemplary American, and an exemplary American was at the very least a civilized man." 66 Lee justified this shift by asserting that some civilization was necessary before any Christianization could happen. On the East Coast, the Methodist board eventually agreed to send more lay people, though they were sure to defend this action to their congregations by saying they should send more good Christians "before the natives become yet more defiled by the proximity and intermingling of unprincipled white men" who were likely to take advantage of American expansion. ${ }^{67}$ The board reassured their members that "the main object of this mission is to covert the

\footnotetext{
${ }^{64}$ Charles Henry Carey, "Methodist Annual Reports," 307-8 as quoted in Gray H. Whaley, Oregon and the Collapse of Illahee: U.S. Empire and the Transformation of an Indigenous World, 1792-1859 (Chapel Hill: The University of North Carolina Press, 2010), 108.

65 Whaley, Oregon and the Collapse of Illahee, 109-110.

66 Lowenberg, Equality on the Oregon Frontier, 95.

67 Twentieth Annual Report, Missionary Society of the Methodist Episcopal Church (1839), p. 12 as quoted in Lowenberg, Equality on the Oregon Frontier, 100.
} 
natives to the knowledge of truth as it is in Jesus." 68 Since colonization was

inevitable, the Methodists thought it best to send good Christians who could serve as examples to the Native and remaining trapper populations.

Lee applied the "convert by example" method to another area entirely: marriage. Lee hoped that Christian marriage would "set off a chain reaction that would ultimately reach into the heathen universe and prod the Indian to climb out of it into the world of the missionary." 69 True to the sentiment, Lee himself took part in one of the first marriages conducted in Oregon under the auspices of God. In the summer of 1837, Miss Anna Maria Pittman, Miss Susan Downing, and Miss Elvira Johnson arrived in Oregon with the first reinforcement of missionaries sent from the East Coast by the Methodist Board. They were all single teachers who were expected to help with the domestic duties of the mission. ${ }^{70}$ Despite initial misgivings, after a short period, Lee proposed to Pittman. ${ }^{71}$ Cyrus Shepard, the mission's well-regarded teacher, also wooed one of the new ladies, Miss Susan Downing. In a triple wedding ceremony, both couples married on July 16, 1837, alongside Charles Roe, an

\footnotetext{
68 Twentieth Annual Report, Missionary Society of the Methodist Episcopal Church (1839), p. 12 as quoted in Lowenberg, Equality on the Oregon Frontier, 100-101.

${ }^{69}$ Lowenberg, Equality on the Oregon Frontier, 113.

${ }^{70}$ Margaret Jewett Bailey, The Grains, or Passages in the Life of Ruth Rover, with Occasional Picture of Oregon, Natural and Moral, ed. Evelyn Leasher and Robert J. Frank (Corvallis: Oregon State University Press, 1986), 3-4.

${ }^{71}$ Lee met Pittman sometime earlier in New York but, as he characterized in his diary, "was not at all favorably impressed with her personal appearance, and least of all, did I think she would ever become my wife; even when I was informed by letter that she was coming to Oregon, and on my first interview with her there, my prejudices remained the same." Jason Lee, "Diary of Reverend Jason Lee - III," The Quarterly of the Oregon Historical Society 17, no. 4 (Dec. 1916), 409.
} 
employee of HBC, and Miss Nancy, a Kalapuyan woman. ${ }^{72}$ Lee's marriage, though a happy occurrence at the time, was the start of one of the most tragic and celebrated tales that arose from the narrative surrounding Jason Lee and the mission in the following seventy years.

Anna Maria Pittman Lee, characterized by her fellows as a devoted missionary and gifted poet, died tragically just a year after her arrival. In the spring

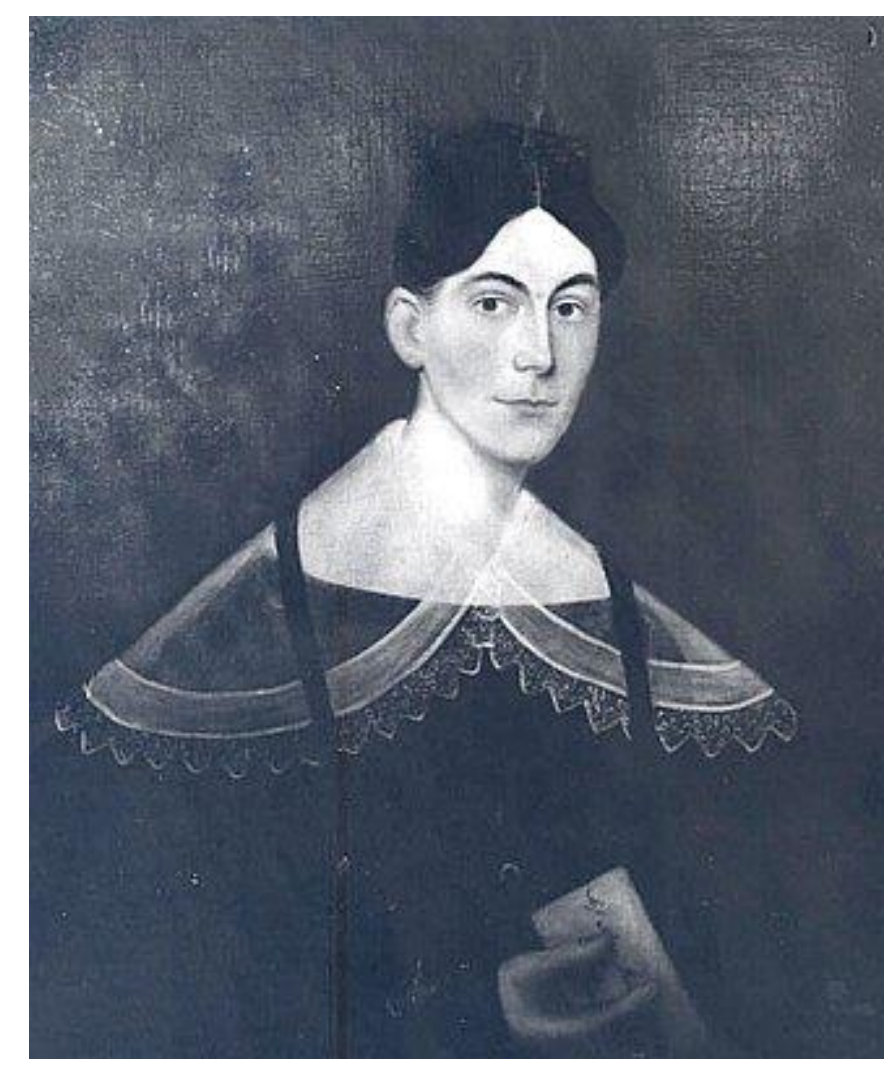

Figure 6: Unknown artist (likely Ammi Phillips), Anna Maria Pittman, c1830, Oregon Historical Society, Catalog Number 11849, Public Domain.

\footnotetext{
72 Theressa Gay, Life and Letters of Mrs. Jason Lee: First Wife of Rev. Jason Lee of the Oregon Mission (Portland: Metropolitan Press), 62-67. Often left out of the multiple wedding story, Charles Roe was later convicted of murdering his second wife, Angelica Carpentier, and was sentenced to hang. He was executed April 2, 1859. See Diane L. Goeres-Gardner, Necktie Parties: A History of Legal Executions in Oregon, 1851-1905 (Caldwell, Idaho: Caxton Press, 2005), 29-30.
} 
of 1838, Pittman Lee was pregnant and Jason Lee left for the East Coast in order to persuade the Missionary Board to send another reinforcement of people. Just a few short weeks after Lee left, Anna Maria Pittman Lee died during childbirth on June $26,1838 .{ }^{73}$ She was the first of the missionaries to die and she and her child, according to many repeated accounts as well as her own gravestone, were the "first white mother and child from Oregon" to die. ${ }^{74}$ She was buried near the settlement at Champoeg, along with her baby son. ${ }^{75}$ Other members of the missionary party died while the mission was located at Mission Bottom. Cyrus Shepard, the well-liked teacher, died on January 1, 1840 and was likely buried near Anna Maria Pittman Lee's grave.

Death was a constant presence at the mission. The Methodists struggled with conversion because so many of the Native people who came to the mission died, "undermining both Native and Methodist goals and contributing to the eventual collapse of Native-colonial comity."76 The mortality rate of the school over its first five years was twenty percent. ${ }^{77}$ One man, Wailaptulikt (given the English name "John Linsey" by the missionaries), brought his family to the mission in July of 1836.

\footnotetext{
${ }^{73}$ Amy E. Platt, Anna Maria Pittman Lee (1803-1838), Oregon History Project (Oregon Historical Society, 2016) https://oregonhistoryproject.org/articles/anna-maria-pittman-lee-18031838/\#.WxCDakgvw2w (accessed May 31, 2018); Theressa Gay, Life and Letters of Mrs. Jason Lee (Portland: Metropolitan Press, 1936), 62-67.

74 "Father Waller" Weekly Oregon Statesman, August 1, 1874, p. 2.

75 "Anna Maria Pittman Lee (1803-1838)," The Oregon History Project, https://oregonhistoryproject.org/articles/anna-maria-pittman-lee-1803-1838/\#.WMN7q2_yvIU (accessed online May 13, 2018).

${ }^{76}$ Whaley, Oregon and the Collapse of Illahee, 116.

77 Of the eighteen people who came to the mission between 1834 and 1835, eight had died by 1838 . For the thirty-four people who arrived between 1836 and June 1838, two died. See Whaley, Oregon and the Collapse of Illahee, 116.
} 
In March of 1837, his youngest son, "Samuel," died of an illness. When his daughter, Tshecooitch ("Clarrisa Perkins"), caught the same illness, he left the mission with his surviving children - and an unpaid bill for $\$ 142.48 .78$

The death of children like Tshecooitch affected the mission both spiritually and financially. At Mission Bottom, a log, probably kept by Cyrus Shepard, tracked the expenses and expenditures of the Mission. This record, which historian Gray Whaley terms a "grim ledger," noted a net gain or loss for any who died while under care of the Mission. Shepard's journal describes the burial of Kenoteshia, a Chehalis boy who died of disease while under care of the mission:

Wed. 19th Aug. 1835 --

This morning at a before three o'clock died Kenthis [sic, Kenoteshia] one of the Indian lads who came to live with us last April, his disease was pulmonary consumption which seized upon him soon after coming here -- his sufferings have been very great which he has borne with exemplary patience -- his remains were decently interred this evening with appropriate exercises in a rural spot selected for a burying place not far from the Mission house -- 0 Lord sanctify this bereavement I pray thee to our present and everlasting good. ${ }^{79}$

He died before he was able to work off the $\$ 25$ in care provided to him..$^{80}$ This ledger is evidence of the practical, if sometimes callous, attitude the missionaries had about operating the mission.

This objectivity on financial matters translated to the spiritual deaths of children like Kenoteshia as well. Rev. H. K. W. Perkins, who arrived in the

\footnotetext{
${ }^{78}$ Whaley, Oregon and the Collapse of Illahee, 116-119.

${ }^{79}$ Cyrus Shepard, Diary of Cyrus Shepard (Vancouver: Clark County Genealogical Society, 1986), 81. Identification of Kenoteshia comes from Whaley, Oregon and the Collapse of Illahee, 119. ${ }^{80}$ Whaley, Oregon and the Collapse of Illahee, 118-119.
} 
second reinforcement in September of 1837, wrote in a letter several years later that he "felt a particular satisfaction in committing these little ones to their mother earth. .... [their] spirits are up on high, and forever more hence beyond the contamination of heathenism." ${ }^{11}$ The deaths of these Native children were important to the work of the Methodist missionaries; however, as becomes clear in the following decades, the actual bodily remains of these children were not as significant.

In 1841, the Mission Bottom location flooded, and the missionaries were forced to choose a new location for themselves and their dead and Lee used their new space to further divide the colonizing efforts from the missionizing. Choosing a site known by the local Kalapuya as Chemeketa, eventually called Salem, Lee and his party developed two sites about a mile away from each other. The mission house and mill site were located near what is today Liberty and D Streets in Salem. The other part of their mission, the Indian Manual Labor School, was located where Willamette University is today. ${ }^{82}$ Historian Robert J. Lowenberg explains the division as Jason Lee's way of separating the civilizing (Manual Labor School) and the missionizing (the mission house)..$^{83}$

\footnotetext{
${ }^{81}$ Rev. H. D. W. Perkins to Charles Pitman, Wascopam, December 4, 1843, University of Puget Sound, as quoted in Lowenberg, Equality on the Oregon Frontier, 85.

82 Judy Chapman, "Willamette Mission," The Oregon Encyclopedia, A Project of the Oregon Historical Society, (entry last updated May 21, 2018), https://oregonencyclopedia.org/articles/jason lee mission willamette mission/\#.WxMDgUgvw2w (accessed June 2, 2018).

${ }^{83}$ Lowenberg, Equality on the Oregon Frontier, 106-139.
} 


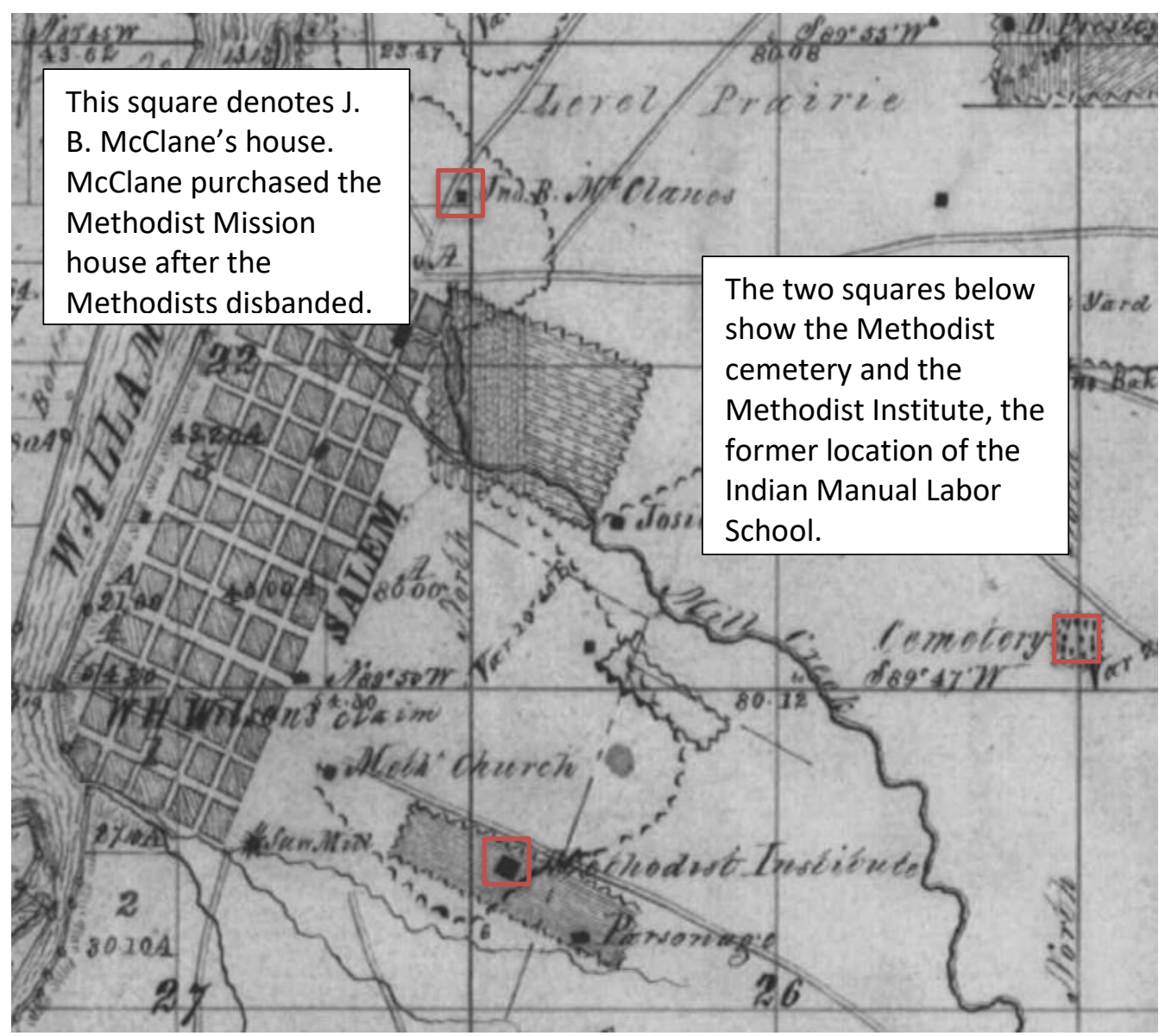

Figure 7: Detail from an 1852 General Land Office Map, available via University of Oregon, GLO Maps, Township 7 South, Range 3 West, Willamette Meridian, https://library.uoregon.edu/map/GIS/Data/Oregon/GLO (accessed September 28, 2018).

Just as death was a constant at Mission Bottom, it cast its shadow over

the new efforts in Salem as well. After the Missionary Society completed the school building in the fall of 1842 , disease again worked its way through the students. ${ }^{84}$ Joseph H. Frost, who spent ten years in mid-nineteenth century Oregon, noted that "there were more Indian children in the mission grave-

${ }^{84}$ Gustavus Hines, Oregon and its Institutions: comprising a full history of the Willamette University, the first established on the Pacific Coast (New York: Carlton and Porter, 1868), 160 as cited in Robert Moulton Gatke, Chronicles of Willamette: The Pioneer University of the West (Portland: Binford and Mort, 1943), 57-58. 
yard at the Walamet ... than there were of such as were alive and in the manual labor school." 85 In fact, with "so few healthy Native converts, the missionaries instead lauded 'happy deaths,' in Daniel Lee's words. That is, they applauded deaths when Indian victims exhibited signs of conversion on their deathbeds." ${ }^{\prime 66}$ The remains of these Native children were probably buried at the site of the "old missionary cemetery," located along today's D Street near the Oregon State Hospital. Not all the Indigenous children were buried here; some remains were claimed by family, much to the chagrin of the missionaries, as that meant no Christian salvation in death. The family of a Wascopam man refused the Christian burial offered by the Methodists, choosing to take the body, as Rev. Waller complained, to "a rock island in the midst of the Dalls." ${ }^{87}$ Death, and the use of the missionary cemetery, was a defining aspect of the missionary experience in Salem for both the Indigenous children who attended the school and the missionaries themselves.

The cemetery would soon gain its first missionary resident as Jason Lee's second wife, Lucy Thompson Lee, died on March 20, 1842, several weeks after giving birth to a daughter named Lucy Anna Maria Lee. Rev. H. K. Hines describes her death is his 1899 history of the mission:

\footnotetext{
${ }^{85}$ Daniel Lee and Joseph H. Frost, Ten Years in Oregon (New York: J. Collord, 1844), 311.

${ }^{86}$ Whaley, Oregon and the Collapse of Illahee, 119.

${ }^{87}$ Alvan Waller, Oregon Historical Society, MS1210, folder 11, 6-7, as quoted in Whaley, Oregon and the Collapse of Illahee, 119.
} 
Her sickness was brief and not considered danger, though attended with a cough and expectoration. On Saturday, March 20, she coughed. Mr. Lee, who was standing by her side, raised her head upon his arm. One gasp and all was over. ${ }^{88}$

Lucy Thompson Lee's death marked an important moment in the history of the Jason Lee Cemetery as her burial is often described as the first in the cemetery. However, there were many deaths at the Mission School both before and after Lucy Thompson Lee - those of the Indian children who attended the school. There is little information about the missionary cemetery during this time. It is likely that the remains of the Indigenous children were buried in a separate location from the missionaries themselves, mirroring the burials at the earlier Mission Bottom location.

By the 1840s, critiques of Lee's failings as administer of the mission were growing, and it was not long before the board dissolved the mission. Hearing complaints about Lee from the mission's own members, namely Reverends Gustavus Hines and William Kone, as well as others, the Methodist board on the East Coast assigned Rev. George Gary to investigate these claims and to "dispose of any property belonging to the Missionary Society, which in his judgment... [was] useless to the Mission." ${ }^{9}$ Meanwhile, Lee anticipated these charges and sailed east in December of 1843 , before Gary arrived. Lee made a case that adequately explained his motives to the Methodist Mission board, though it was too late to recall Gary

\footnotetext{
${ }^{88}$ H. K. Hines, Missionary History of the Pacific Northwest: containing the wonderful story of Jason Lee (Portland: H. K. Hines, San Francisco: J. D. Hammond, 1899), 244.

${ }^{89}$ Robert Moulton Gatke, "A Document of Mission History, 1833-43," Oregon Historical Quarterly 36, no. 1 (1935): 90-91, as quoted in Whaley, Oregon and the Collapse of Illahee, 133-135,
} 
from his task. Lee was compensated for the loss of the mission with the title of "Agent of the Oregon Institute," even though the church would not officially support the school..$^{90}$ This new school, an outgrowth of the failed Indian Manual Labor School, in Lee's vision, would serve the children of white settlers who were becoming larger in number every year. By 1844, Gary had divested most of the land holdings and largely ended the mission in Oregon, citing the Indians as a wholly lost cause. As the mission no longer needed the building which used to house the "Indian Manual Labor School," Gary sold the building to the trustees of the "Oregon Institute," which eventually became Willamette University. This school served as another impetus for the settlement of Salem: even before the arrival of Rev. Gary, the mission and education work had turned from educating Native children to principally serving the children of white settlers in the area, clear evidence that the missionaries themselves had gradually abandoned the idea of Christianizing the Natives. ${ }^{91}$

Lee, while visiting his home in Canada after a fundraising effort for the new school, died on March 12, 1845, his reputation tarnished by his failed attempt to bring Christianity to Oregon. He was buried in Stanstead, Quebec. Lee's failure to make any real headway in the conversion of the Natives, in addition to his "habitual delinquency" in sending the board mission account and activities, resulted in a Board that was "very much dissatisfied with [him] on account of apparent

${ }^{90}$ Lowenberg, Equality on the Oregon Frontier, 76-77.

${ }^{91}$ Whaley, Oregon and the Collapse of Illahee, 147; Lowenberg, Equality on the Oregon Frontier, 76. 
neglect."92 The Methodist Mission board saw Lee's ten years of work, resulting in a mere land claim and a school for the children of white settlers, as an embarrassment.93 The title of agent to the Oregon Institute was not an honor per se, but simply because "some disposition must be made of him." 94 Easterners were dismissive of Lee's work and his own mission members were the ones to complain to the Methodist Board about his management of the mission. When he died, his reputation was blemished, to say the least.

In the years after the dissolution of the mission, historians and contemporaries had different reactions or memories of Jason Lee and his work. In a book originally published in 1846, Rev. C.G. Nicolay relates the views of Lieutenant Wilkes, who visited the mission while it was still in operation in 1841 . He recorded the following observations: "I must own I was greatly disappointed, for I had been led to expect that order and neatness at least... would have been found among [the Indians boys at the mission], considering the strong force of Missionaries engaged here." 95 He continued that the missionaries had made "individual selections of lands to the amount of one thousand acres each, in prospect of the whole country falling under the American dominion."96 Based on these observations, Nicolay then makes

\footnotetext{
92 Lowenberg, Equality on the Oregon Frontier, 7.

${ }_{93}$ Lowenberg, Equality on the Oregon Frontier, 76-77.

${ }^{94}$ Charles Pitman to George Gary, New York, January 6, 1845, University of Puget Sound, as quoted in Lowenberg, Equality on the Oregon Frontier, 77.

${ }^{95}$ Emphasis in original. Rev. C. G. Nicolay, The Oregon Territory: a geographical and physical account of that country and its inhabitants with outlines of its history and discovery (London: Charles Knight \& Co., 1846, reprinted London: W.C. \& J. Penny, Frome, 1886), 127.

96 Ibid.
} 
the point that is was no surprise that the missionaries were the first to "excite political changes."97 Both Wilkes and Nicolay portray the missionaries as opportunistic colonizers, not faithful missionaries.

There were those who tried to rectify this interpretation. The 1850 work by former Methodist Missionary to the Oregon Mission, Rev. Gustavus Hines, was complimentary (somewhat surprising since Hines was one of the men who complained to the Methodist Mission board about Lee's administration). The book, in the words of the author, would "supply the Christian public with a needful desideratum, with respect to the true character of that important Mission."98 The emphasis on "needful" and "true character" implies that Hines was working against a prevailing negative impression of Jason Lee and the mission in the years after his death. On describing Lee's dismissal, Hines is careful to defend Lee: “Mr. Gary had been appointed to supersede Mr. Lee... arising from the supposition founded in the statements of missionaries, oral and written, that they 'had been misled as to the necessity of so great a number of missionaries in Oregon,' ... These objections... should not be considered as any disparagement to the character of Mr. Lee." Hines goes on to explain why Lee never submitted the correct financial reports to the Board: "after the account of the mission were committed to the keeping of Mr.

\footnotetext{
97 Ibid.

${ }_{98}$ Gustavus Hines, $A$ voyage round the world: with a history of the Oregon mission : and notes of several years residence on the plains, bordering the Pacific Ocean : comprising an account of interesting adventures among the Indians west of the Rocky Mountains : to which is appended a full description of Oregon Territory, its geography, history, and religion; designed for the benefit of emigrants to that rising country (Buffalo: George H. Derby and Co., 1850), iii.
} 
Abernathy, it was impossible for Mr. Lee, or any other man, to make out the reports," even though Hines "was aware that Mr. Lee... was the responsible man."99 Hines paints Lee as a honorable and wrongly accused man, simply the subject of the Board's misplaced anger about the mission's failure to convert and Natives to Christianity.

Regardless of Hines' attempts to stem the flow of disparaging words against Lee, historian Frances Fuller Victor's later interpretation of Lee was a clear indication that Hines was not successful. Victor is credited with writing the Oregon volumes of H. H. Bancroft's massive Works series, published in $1886 .{ }^{100}$ She painted Lee as a failed speculator, more interested in the financial potential of the Willamette Valley than the word of God. Victor characterized the efforts of the missionaries as "a curse," and "a burst peatbog sowing its black mud over the land." 101 Her account of Shepard's death surmised that "with Shepard died all interest in the hopeless scheme of educating the native children of the Willamette."102 She was critical of Lee's arrival in 1840 when he returned with a new wife: he "handed over the ship's list of passengers, headed by the name of Mr and Mrs Jason Lee... He made no remark on the subject and nothing was said to him.

\footnotetext{
99 Ibid., 236-237.

100 Sheri Bartlett Browne, “Frances Fuller Victor," Oregon Encyclopedia, last updated July 12, 2018, accessed October 3, 2018, https://oregonencyclopedia.org/articles/victor frances fuller/\#.W7UWPGhKhPY. ${ }^{101}$ Hubert Howe Bancroft (written by Frances Fuller Victor), The Works, vol. XXIX, History of Oregon, vol. 1, 1834-1848 (San Francisco: The History Company, 1886), 89, accessed via Archive.org on October 2, 2018, https://archive.org/details/worksbancro29bancuoft/page/n9. 102 Bancroft (Victor), Works, 18.
} 
Deeply stirred had been the sympathies of his old associates as they thought of his return to his desolate home; and now the revulsion of feeling was so great that the supremacy of Jason Lee in their hearts was thenceforth a thing of the past."103 In Victor's interpretation, Lee was an unorganized faux missionary.

If Lee had such a bad reputation for decades after his death, how did he become one of the most celebrated men of Oregon's history? The answer to that question lies in the story of Jason Lee's triumphant return to Salem some sixty years after his death. Oregonians were eager to rework the story of Lee to emphasize the colonizing aspects of his work as the precursors to Oregon's success and financial promise. The "old Methodist cemetery," later renamed the Jason Lee Cemetery, eventually became the perfect place to solidify his memory as the founder of American Oregon.

The cemetery in Salem eventually became the one most closely associated with Lee and his company, even though it was not the first cemetery the missionaries utilized. In 1909, reporter R. A. Eaton pondered to his readers: "I was puzzled to know how the old Mission burying ground came to be at Salem when the Mission was founded on the bank of the Willamette eleven miles below."104 Eaton turned to John Minto, an early settler of the area who purchased the Mission Bottom donation land claim after the missionaries left. According to Minto, bodies (likely Anna Maria Pittman Lee, Cyrus Shepard, and some others) were moved from the

103 Bancroft (Victor), Works, 183.

104 Ibid. 


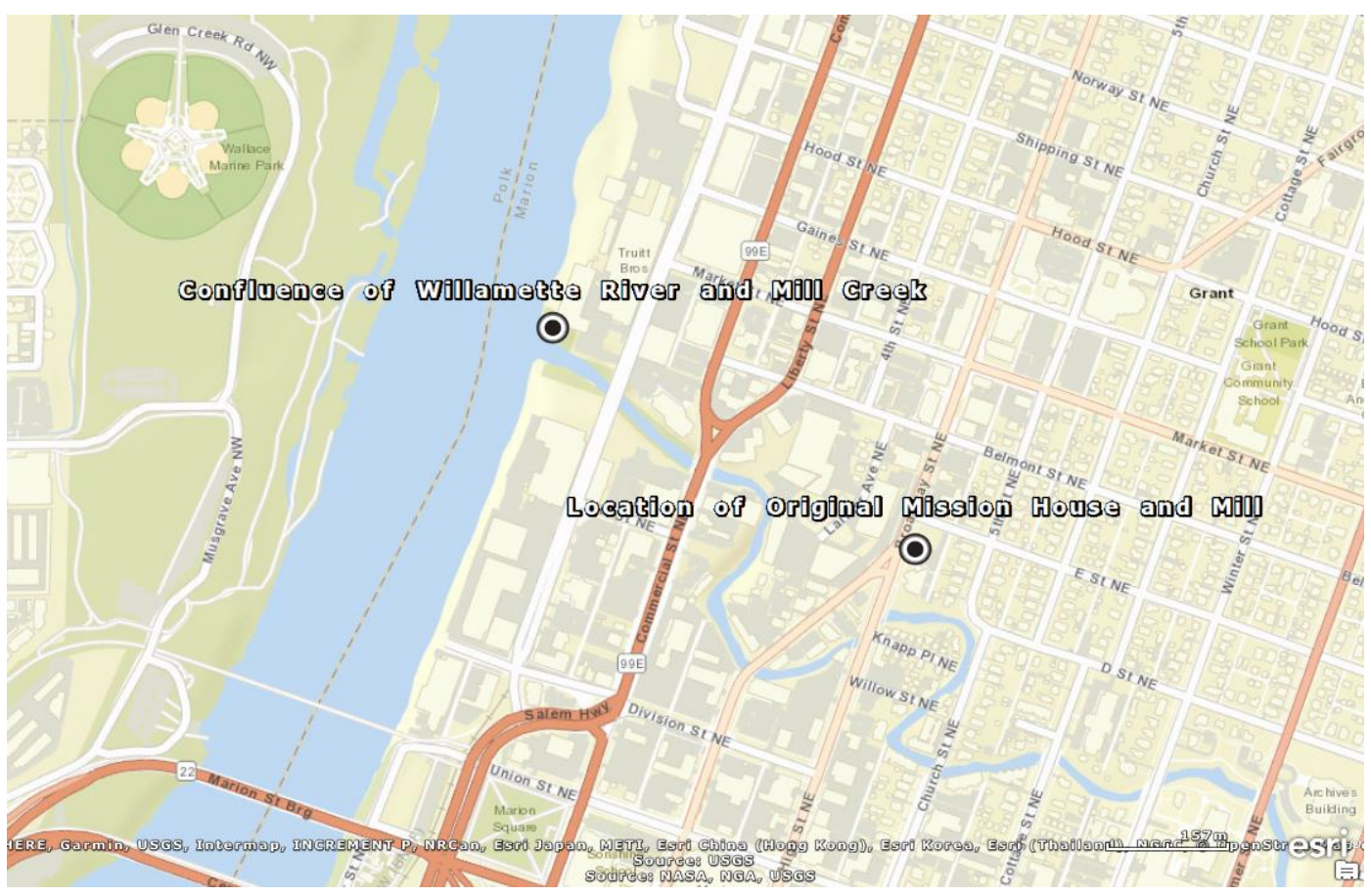

Figure 8: This map shows the relative location between the possible boat launch and the original location of the Mission house in early Salem. Map created using ArcGIS Explorer.

original graveyard around 1844 or 1845 and reburied near "what was the boat landing for Salem at the time."105 The location of the original boat launch is somewhat unclear, but it was likely near the location of the confluence of the Mill Stream and the Willamette River. According to another newspaper account, the first cemetery in Salem was located north of town, near the house of J. B. McClane.106 McClane purchased the Methodist mission home sometime after Gary closed the mission, probably by 1850 , so these two references are likely about the same burial place. ${ }^{107}$

105 R. A. Eaton, “An Historical Place," Albany Democrat, October 22, 1909, p. 6. 106 "The First Graveyard," Weekly Salem Mercury, April 29, 1871, p. 3, col. 4, available at Willamette Heritage Center, Cemetery Research Subject File.

107 McClane was the first postman in Salem and ran the post office from the old mission house at 960 Broadway Street, which he purchased after the mission dissolved. See Ben Maxwell, "Display in Bank Lobby Tells of First Mail Service Here," Daily Capital Journal, October 26, 1949, p. 19. 
However, the record remains unclear as there are other accounts that the bodies were moved directly to the Jason Lee Cemetery. In 1933, R. J. Hendricks, an editor of the Oregon Statesman who often published a column that included tidbits about Salem's history, requested information from his readers about the date of the "removal from the old mission cemetery of the bodies of Anna Maria Pittman Lee and newly born son and Cyrus Shepard, to the Lee Mission Cemetery."108 In October of the same year, he published a partial response to this question. Though he did not have a date, Hendricks reported that the bodies of these three were probably disinterred sometime around the burial of Lucy Thompson Lee (March 1842). That generally lines up with previous date give by John Minto in 1909, who reported they were disinterred around 1844 or 45 . However, according to an 1872 newspaper article, the bodies in the North Salem, boat-launch cemetery would "be removed to the old Missionary Cemetery." 109 So who was buried in the North Salem cemetery? Who was removed to the Lee Mission Cemetery in the 1870s? Since the "old Missionary Cemetery" was already known by that name in 1872, there were clearly burials there which were already associated with the mission. While the record may never reflect exactly who was disinterred when, it is reasonable to assume that the missionaries exerted great effort to reinter the remains of Anna Maria Pittman Lee and Cyrus Shepard in Salem sometime in the 1840s.

\footnotetext{
108 R. J. Hendricks, “Bits for Breakfast,” Oregon Statesman, January 19, 1933, p. 4. 109 “The First Graveyard," Weekly Salem Mercury, April 29, 1871, p. 3, col. 4, available at Willamette Heritage Center, Cemetery Research Subject File.
} 
In direct opposition to the effort taken to reinter Anna Maria Pittman Lee and Cyrus Shepard, the bodies of the many Native children who died at the Mission Bottom location were never moved. Hendricks reported that "all the bodies of white persons were removed - all but perhaps one. There is a tradition that the body of a child of Rev. J. L. Parrish was never removed. None of those in the Indian cemetery, further south, at the old mission, were ever removed - nor is there a sign now of the location of either cemetery." 110 Recalling that the spiritual deaths of Native children were important to the success of the mission, leaving the bodies of these same children when they could have also been removed to Salem is evidence that some of the missionaries were ultimately unconcerned with the remains, and thus the people, who they were supposedly there to help.

The differences between the treatment of the remains of the missionaries and the Indigenous students of the mission, as well as the treatment of Native remains and objects in other parts of America, illustrate the dismissal of Native people (alive and dead) by the missionaries, colonists, and U.S. Government, as well as stands as a larger metaphor for Euro-American resettlement on the West Coast. As the remains were forgotten in death, Native people were forgotten or ill-treated in life. Contributing to the dismissal of Indigenous autonomy was the archeological examination of Native remains and objects on the East Coast. Thomas Jefferson, a founder of the philosophy of American agrarianism which largely inspired the

110 R. J. Hendricks, “Bits for Breakfast," Oregon Statesman, October 3, 1933, p. 4. 
migration west and an amateur archaeologist, excavated an Indian burial ground on his property at Monticello circa $1780 .{ }^{111}$ By the 1850 s, advancement in the realm of evolutionary theory and theories about age of human-kind had excited Europeans and Americans into excavating, collecting, and storing "hundreds of thousands of Native American skeletons and skeletal parts in museums."112 In 1862, Surgeon General William A. Hammond asked field medical doctors and officers to send "Indian specimens" back to Washington in order to advance the study of infectious disease. ${ }^{113}$ One of the clearest examples of disregard for living Native people in the Willamette Valley was the fact that while officially, colonists "pledged not to seize Indian lands without consent and compensation," in reality, colonists outright ignored the legal notion of Indigenous sovereignty and claimed large swaths of land in the so-called "Indian Country."114

There are several possible reasons why the remains of the Indian children of the Methodist mission were spared from archeological investigation. Since the received a Christian burial, the missionaries would have buried them without any grave goods, making them an unlikely target. It may just as well be that they were

\footnotetext{
${ }^{111}$ Gene Zechmeister, "Jefferson's Excavation of an Indian Burial Mound," Thomas Jefferson Encyclopedia, November 2011, accessed October 3, 2018, https://www.monticello.org/site/research-and-collections/jeffersons-excavation-indian-burial$\underline{\text { mound. }}$

112 Fine-Dare, Grave Injustice, 20.

113 Ibid, 33. See also Ann Fabian, The Skull Collectors: Race, Science, and America's Unburied Dead (Chicago: University of Chicago Press, 2010) for an in-depth discussion about the pattern of skullcollecting in America. See especially, the chapter "A Native among the Headhunters," to learn about Lee's interaction with a young Chinook convert named William Brooks and his influence on both the Methodist mission and the "naturalist" community on the East Coast.

114 Whaley, Oregon and the Collapse of Illahee, 161-162.
} 
simply forgotten before this archeological fervor spread to the West Coast. Or possibly, as these Native children had been buried according to Christian tradition, they were provided with some sort of spiritual protection not afforded to their "less civilized" kin. Kalapuya burial mounds in the same area were the subject of archeological investigation and looting in the early twentieth century. ${ }^{115}$ But even Christian burial could not protect these remains from obscurity. Today they go unrecognized. An archeological investigation of the original Willamette mission in the 1980s uncovered no burials, though the land where these burials took place is probably within the bounds of what is now Willamette Mission Oregon State Park. ${ }^{116}$ Further investigation may one day uncover these burial places and perhaps a proper memorial could be placed.

In Salem, even though the Mission was dissolved in 1844, population and investment were beginning to boom, largely because the infrastructure originally erected by the missionaries made Salem a desirable place to live. A description from March of 1844, just a few months before Gary dissolved the mission in Salem, details some of this development. Salem was the "principle town of Oregon," and according to the author, had over "two hundred families." There are also amenities like a church, school, mills, and comfortable dwellings. While this description is likely exaggerated, the account of Salem as one of the most well-developed towns in the

\footnotetext{
115 David Lewis, "Mounds of the Tualatin-Yamhill Kalapyan Area," NDNHistory Research: Indigenous, Public \& Critical Essays, August 1, 2017, accessed October 3, 2018, https://ndnhistoryresearch.com/2017/08/01/mounds-of-the-tualatin-yamhill-kalapuyan-area/. 116 Judith A. Sanders, Mary K. Weber, David Ray Brauner, Willamette Mission archeological project: phase III assessment (Corvallis: Department of Anthropology, Oregon State University, 1983).
} 
Oregon Country at that time with "all the accompaniments of civilization and refinement" reflects that it was at least well-developed when compared to other towns in the area. ${ }^{117}$ In 1846, the United States and Great Britain agreed to a treaty which divided the disputed country of the Pacific Northwest at the $49^{\text {th }}$ parallel. In August of 1848, Oregon became an official territory of the United States. ${ }^{118}$ In 1850 , William H. Willson, a former member of the Methodist Mission, filed a plat for the city with the Marion County clerk. ${ }^{119}$ While Salem was never a contender for the status of largest city after Portland started to develop, it was always an important place for government in the Oregon Territory, thanks in no small part to the role the Methodist Mission played in the colonization of Oregon.

One of the fiercest competitions between the new cities of Oregon, and one that would eventually influence the reinterment of U.S. Representative Samuel R. Thurston, was a contest over which would become the capital. During the second session of the legislature of the Territory of Oregon in 1849, while meeting in Oregon City, officials passed a bill locating the seat of the Territorial Government in

\footnotetext{
117 George Wilkes, who wrote the book that this description comes from, was imprisoned at another point for libel and his works have a reputation for being somewhat exaggerated. The quotes above come from part two of his work about Oregon, which is a collection of letters written by an early Oregon resettler who is not identified in the original book. Later historians identified the source of these letters as Peter Burnett, a California Governor and the author of the infamous Black exclusionary laws of early Oregon. For quotes see George Wilkes, An Account of History of the Oregon Territory: Together with a Journal of an Emigrating Party across the Western Prairies of America and to the Mouth of the Columbia River (London: W. Lott, 1846), 133; for identification of the letter writer see Clarence B. Bagley, "George Wilkes," The Washington Historical Quarterly 5, no. 1 (January 1914), 3-4; and for information about Burnett see Greg Nokes, "Peter Burnett (1807-1895)," The Oregon Encyclopedia, entry last updated March 17, 2018, accessed June 3, 2018, https://oregonencyclopedia.org/articles/burnett peter/\#.WxRI3Ugvw2w. ${ }_{118}$ Echoes of Oregon, 1837-1859 History Learning Guide, "Oregon Territorial History," Oregon Secretary of State, accessed May 20, 2018, http://sos.oregon.gov/archives/exhibits/echoes/Pages/history.aspx.

119 Tom Fuller and Christy Van Heukelem, Salem (Charleston: Arcadia Publishing, 2009), 7.
} 
Salem. The construction of the new capital building began in 1854, but even with this permanent step, in 1855 , the sixth session of the territorial legislature passed an act which moved the seat to Corvallis. The United States Treasury stepped in and declared that federal money could only be spent in Salem and that settled the matter for a time. However, just after Christmas 1855, a fire ravaged the new capital building. Arson was suspected, but never proven. Oregon was admitted to the union on February 14, 1859, but the capital question remained unsettled. The difficulty was put to the voters and finally, in 1864, nearly fifteen years later, Oregonians voted for Salem as the official capital city of the State of Oregon. ${ }^{120}$

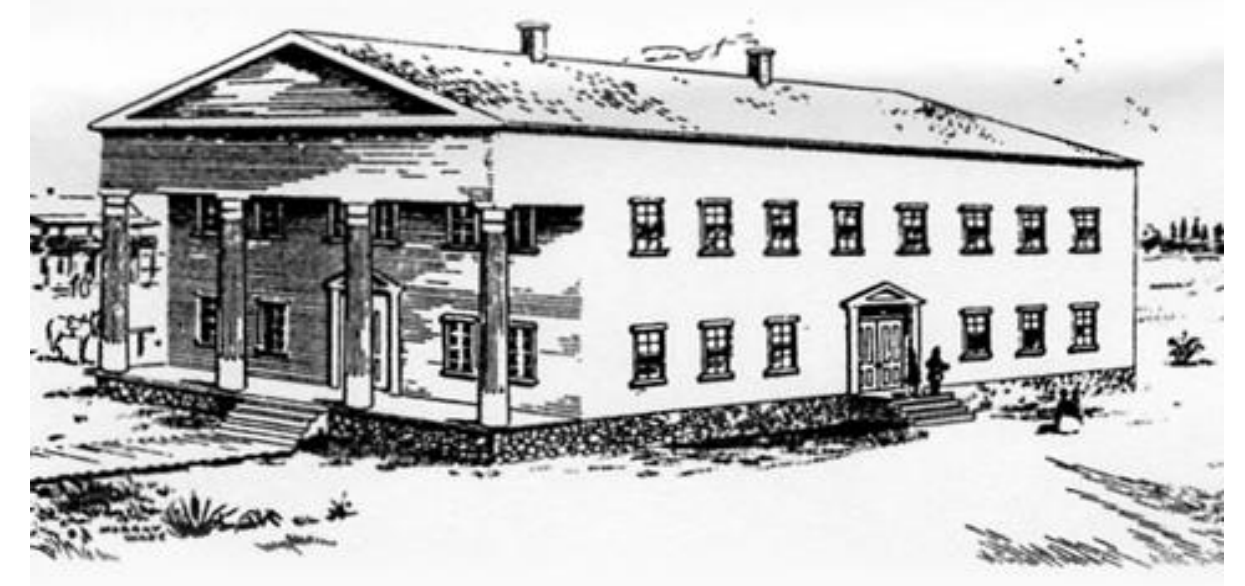

Figure 9: This engraving shows the first Territorial Capitol Building, burned in 1855. Photo courtesy Oregon State Legislature.

Almost by happenstance, Salem was the designated capital when Oregon's first Congressional delegate, Samuel Royal Thurston, died while on the way to his

120 Walter C. Winslow, "Contests over the Capital of Oregon," The Quarterly of the Oregon Historical Society 9, no. 2 (June 1908), 174-178. 
home from Washington, D.C. on April 9, 1851.121 Thurston had originally arrived in Oregon in 1847 and established a legal practice in Oregon City. Oregonians elected him to the United State Congress in 1849 , and as a Democrat, he supported the expansionist party leaders. He helped pass the Oregon Donation Land Claim Act in 1850, his most influential achievement despite his no-vote status. This act legitimized the land claims of Euro-American settlers in the Pacific Northwest, despite Indigenous claim or treaty status. Historian John Suval terms this political brand "Squatter Democracy."122 This act encouraged settlement in Oregon as it promised 640 acres of land for free to any couple who could stay on the land, and 320 acres to any man. Only a few months after this feat, Thurston died from an unknown illness just after crossing over Panama. Though any regular passenger would have received a burial at sea, since Thurston was a public figure, he was taken ashore at Acapulco and buried. ${ }^{123}$ Largely thanks to his huge impact on the later settlement of Oregon, he would not be buried there for long.

In Salem, still the seat of the Territorial Government, some prominent Oregonians were agitated by the fact that such an important Oregonian figure would be left unrecognized on the Mexican shore, so they organized to bring him home. The Territorial Legislature passed a bill on January 1852 which provided $\$ 1,500$ for

\footnotetext{
121 Biographical Directory of the United States Congress, 1774-present, "Thurston, Samuel Royal (1816-1851)," United States Congress, accessed May 20, 2018 http://bioguide.congress.gov/scripts/biodisplay.pl?index=T000258. 122 John Suval, "'The Nomadic Race to Which I Belong': Squatter Democracy and the Claiming of Oregon," Oregon Historical Quarterly 118, no. 3 (Fall 2017), 306-337, accessed online July 28, 2018, http://www.jstor.org/stable/10.5403/oregonhistq.118.3.0306. 123 Elisabeth Warren Potter, “Odd Fellows Rural Cemetery," National Register of Historic Places Nomination Form, (Salem, Oregon 2013), 30.
} 
the reinterment of Thurston's remains in Oregon soil. The three men appointed to the committee were Adam Van Dusen from Astoria; William M. King from Portland; and William H. Willson from Salem. Thurston's brother in law, B. F. McLench, took on the task of removing Thurston's remains from Mexico. McLench landed in Portland on March 3, 1853 and the remains were taken to the capital, Salem. ${ }^{124}$ The Methodist Church in Salem held a memorial for the fallen legislator and his remains were "deposited near the old church," which was located at the southeast corner of State and Church Streets. ${ }^{125}$ Samuel R. Thurston, in death, was worshiped as the ideal Oregon colonizer; his martyred remains were a physical reminder of the sacrifices that resettlers had made to come to Oregon and erecting a proper monument was a symbol of the prosperity that would arise from those sacrifices. To have Thurston buried in Salem, the territorial capital, was an honor and helped legitimate the city's claim to the capital.

Salemites, aware of the significance, celebrated his funeral with all the appropriate pomp and circumstance. The paper covered the event with an entire page dedicated to Rev. Delazon Smith’s April 12, 1853 lengthy eulogy (it took several weeks for the paper to publish the entire thing in sections). ${ }^{126}$ Citizens sent in poetry to honor the man:

Come to the tomb of the honored dead,

\footnotetext{
124 Ibid.

125 Mary A. Gray McLench, “Early Day Teachers," Ladd and Bush Quarterly 3, no. 2 (January 1916): 2, accessed via Google Books on May 21, 2018, https://books.google.com/books?id=264aAQAAMAAI\&vq=cemetery\&dq=ladd\%20and\%20bush\&pg =RA2-PA9\#v=onepage \&q=mclench \&f=false. 126 See "Funeral Discourse," Weekly Oregon Statesman, April 23, 1853, p. 2 and "Funeral Discourse," Weekly Oregon Statesman, April 30, 1853, p. 1.
} 


\begin{abstract}
Ye stalwart men of Oregon;
Heed the sacred sod you tread,

Here sleeps her noblest son!

...

His voice was loud in your defence [sic],

His arm was strong for right;

His deed will live forever hence, As emblems of his might. ${ }^{127}$
\end{abstract}

At this point in time, Thurston was arguably the most famous Oregonian. After learning of his death, citizens encouraged the legislature to name a county after him, which they eventually did (now in Washington State). ${ }^{128}$ His contributions to the Oregon Territory with the passage of the Oregon Land Donation Act were greatly admired and appreciated so his remains were treated with great honor. And this would not be the last of Thurston's celebration. Thurston remained buried behind the Church yard for one year. When the time was right, Salemites removed Thurston to Oregon's first official rural-style cemetery, the Odd Fellows Rural Cemetery.

The Independent Order of the Odd Fellows, Chemeketa Lodge No. 1 was one of the earliest and most influential lodges to develop in newly colonizing Oregon. Internationally, the I.O.O.F. is an organization with origins in the industrial towns of Britain. During British immigration to America, the lodge came too, and in 1819, the largest British Society, the Manchester Unity, chartered a lodge in Baltimore, Maryland. By 1833 Americans started their own branch of Odd Fellows, separate from the British. The spread of I.O.O.F. lodges followed the pattern of white

127 L. F. G., "Thurston," Weekly Oregon Statesman, April 16, 1853, p. 1. 128 "Friend Bush," Weekly Oregon Statesman, August 5, 1851, p. 1. 
settlement from the 1850 s to the 1930 s. ${ }^{129}$ Oregon was no different. The first branch in the Pacific Northwest of Odd Fellowship was chartered in Salem in 1852, I.O.O.F. Chemeketa Lodge No. 1.130 Generally, the Odd Fellows offered myriad benefits to their members: "sick insurance," funeral benefits, occasionally widow's or orphan's insurance, discretionary aid to members in distress, and access to I.O.O.F. homes for widows, orphans, or aged members. They could also help locate employment, business contracts, or sources of credit, along with social benefits "such as respectability, fellowship, intimacy with other men, entertainment, and ritual that bolstered male confidence."131 Death rites were also very important to Odd Fellows and many lodges purchased and established cemeteries in new cities and towns across the country. ${ }^{132}$

Just a couple years after their formation, Chemeketa Lodge No. 1 was one of many lodges across the country that undertook an organized and detailed effort to provide the citizens of Salem with a respectable cemetery, much earlier than almost any other organized effort for a rural cemetery in the territory. On April 10, 1854, the Brothers resolved to form a joint committee with the Masonic Fraternity to

\footnotetext{
${ }^{129}$ George Emery and J. C. Herbert Emery, A Young Man's Benefit: The Independent Order of Odd Fellows and Sickness Insurance in the United States and Canada, 1860-1929 (Montreal \& Kingston: McGill-Queen's University Press, 1999) 19.

130 The first officers were Benjamin F. Harding, Nobel Grand, E.N. Cooke, Vice-Grand, A. J. Woodworth as Secretary, Joel Palmer as Treasurer. See David Duniway, "Chemeketa Lodge No. 1 Odd Fellows Building," National Register of Historic Places Registration Form (Salem, Oregon 1987), sec. 8, p. 4. 131 Emery and Emery, A Young Man's Benefit, 24.

132 Don R. Smith and Wayne Roberts, The Three Link Fraternity: Odd Fellowship in California (Linden Publications, 1993), excerpts accessed May 5, 2018 at IOOF.org, http://www.ioof.org/IOOF/About Us/IOOF History/history nowandthen/IOOF/AboutUS/history t henandnow.aspx?hkey=8330481b-28c0-44cd-b4e5-4cc86a87a102.
} 
"confer in relation to procuring a site suitable for a cemetery"; the members of the

Odd Fellows committee were A. W. Ferguson, E. M. Barnum, and Chester N. Terry. ${ }^{133}$

As of May 1, the committee reported that they had found "a suitable place for a cemetery" and were given permission to purchase the land on behalf of the Lodge;

by July, they started improving the land. ${ }^{134}$ In August, the payment of $\$ 62.50$ was

drawn in order to pay former Methodist missionary David Leslie for the cemetery

ground. ${ }^{135}$ In October, Secretary C. A. Reed recorded a payment of twenty-five

dollars to pay for half of the clearing of the land. ${ }^{136}$ In December, Jonathan O. Donald, James Strang, D. G. Raymond, E. N. Cooke, C. A. Reed, and Manly Danforth were appointed to assist in the survey of the burial ground; they officially decided to occupy the cemetery "conjointly" with the Masonic Fraternity and the plot was officially accepted. ${ }^{137}$ Later in December, Secretary E. M. Barnum recorded a motion that passed in response to the Masonic Fraternity's request that the "form of the cross" be omitted from the plat of the cemetery. The Brothers approved "such form of ground instead of the Cross as they may deem proper" in its place. ${ }^{138}$ In January,

\footnotetext{
133 IOOF Meeting Minutes, April 10, 1854, Chemeketa Lodge No. 1 Record Book (Dec. 6, 1852-Jun. 30, 1857), Salem IOOF Record Room, Salem, Oregon.

${ }^{134}$ IOOF Meeting Minutes, May 1 and July 17, 1854, Chemeketa Lodge No. 1 Record Book (Dec. 6, 1852-Jun. 30, 1857), Salem IOOF Record Room, Salem, Oregon.

135 IOOF Meeting Minutes, August 14, 1854, Chemeketa Lodge No. 1 Record Book (Dec. 6, 1852-Jun. 30, 1857), Salem IOOF Record Room, Salem, Oregon.

${ }^{136}$ IOOF Meeting Minutes, October 23, 1854, Chemeketa Lodge No. 1 Record Book (Dec. 6, 1852-Jun. 30, 1857), Salem IOOF Record Room, Salem, Oregon.

${ }^{137}$ IOOF Meeting Minutes, December 4, 1854, Chemeketa Lodge No. 1 Record Book (Dec. 6, 1852-Jun. $30,1857)$, Salem IOOF Record Room, Salem, Oregon.

138 The plat of the IOOF Rural Cemetery now resembles a heart. IOOF Meeting Minutes, December 11, 1854, Chemeketa Lodge No. 1 Record Book (Dec. 6, 1852-Jun. 30, 1857), Salem IOOF Record Room, Salem, Oregon.
} 


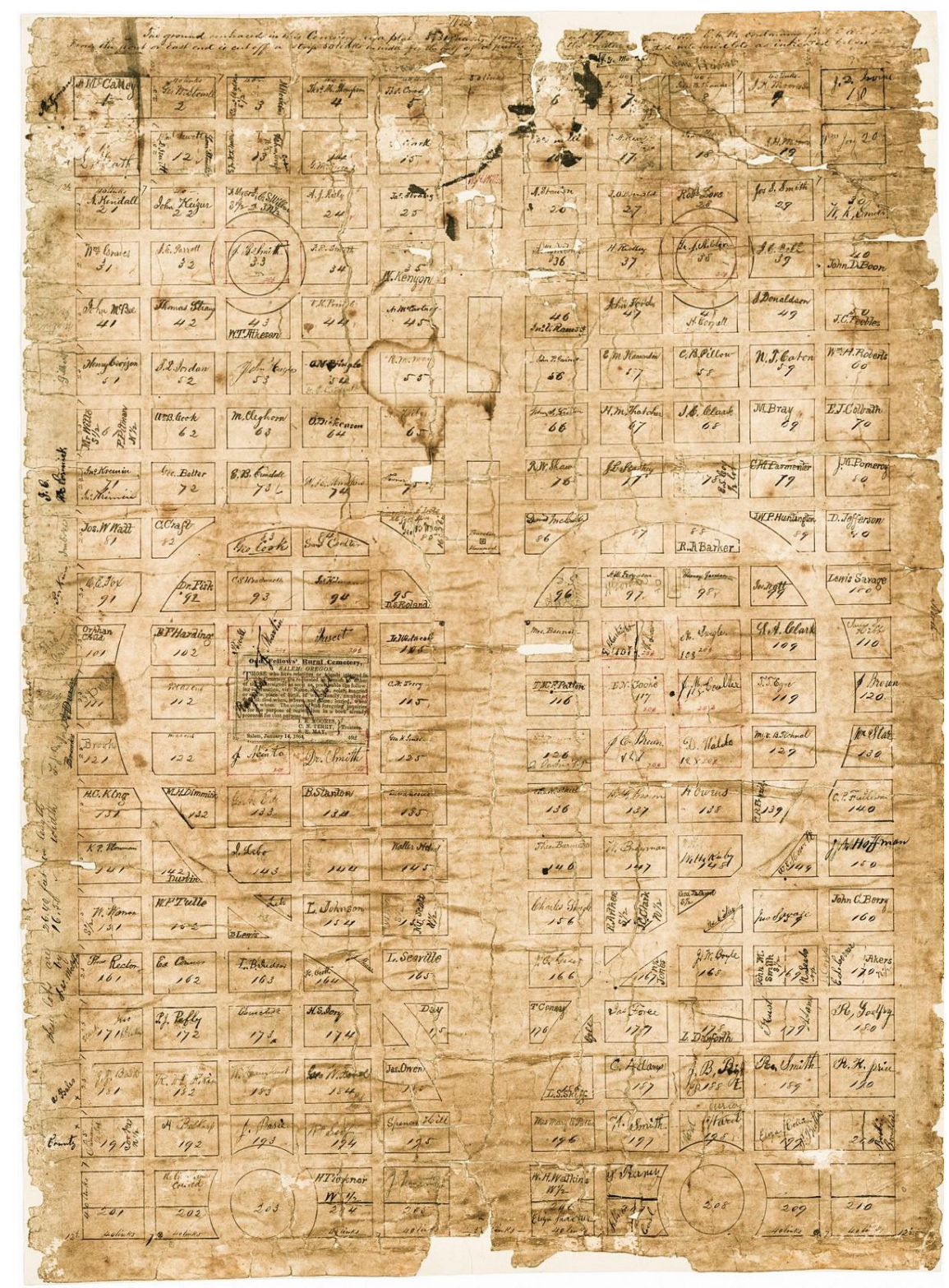

Figure 10: Odd Fellows Rural Cemetery, pen and ink drawing, layout of initial five acres, Plots 1 through 210, c. 1854-1860. Courtesy of The Friends of the Salem Pioneer Cemetery and as cited in Elisabeth Warren Potter, "Odd Fellows Rural Cemetery," National Register of Historic Places Nomination Form, (Salem, Oregon 2013), 56.

the Brothers began selling the plots and building a fence around the cemetery. ${ }^{139}$

Despite all this quick progress, for unknown reasons, the Masonic Lodge decided to stop supporting the cemetery effort. On May 14, 1855, Lodge members approved 
paying the Masons a sum of $\$ 87.50$ to settle all cemetery business with them. ${ }^{140}$ This was the start of the Odd Fellows Rural Cemetery (now known as the Salem Pioneer Cemetery) as Salemites still recognize it today.

In 1856, after the Brothers established the cemetery and it had begun receiving burials, attention again turned to the remains of Samuel R. Thurston, though this second reburial was much quieter than the preceding. In January 1854, the legislature had apportioned money to pay for the erection of a monument to Thurston at his gravesite. Due to some problems with the sourcing of the marble, the monument was not finished until April of 1856 - just a few months after the first Oregon Territory Capital had burned in December of 1855.141 The committee in charge of his reburial had arranged with Chemeketa Lodge No. 1 to rebury Thurston's remains in the new rural cemetery south of town. He was to receive a prominent spot, right at the top heart design, with a view over the city of Salem and Mount Hood. ${ }^{142}$ The monument, which still stands in the cemetery today, was large, made of Vermont marble and was inscribed with the words “here rests Oregon's first Delegate, a man of genius and learning, a lawyer and statesman; his Christian virtues equaled his wide philanthropy; his public acts are his best eulogium."143 This

\footnotetext{
140 IOOF Meeting Minutes, May 14, 1855, Chemeketa Lodge No. 1 Record Book (Dec. 6, 1852-Jun. 30, 1857), Salem IOOF Record Room, Salem, Oregon.

141 “The Thurston Monument," Weekly Oregon Statesman, April 1, 1856, p. 2.

142 Elisabeth Warren Potter, “Odd Fellows Rural Cemetery," National Register of Historic Places Nomination Form, (Salem, Oregon 2013), 31.

143 “The Thurston Monument," Weekly Oregon Statesman, May 20, 1856, p. 2.
} 
is the extent of the coverage of the event in the newspaper, and as a whole, the second reinterment "was done without public ceremony."144

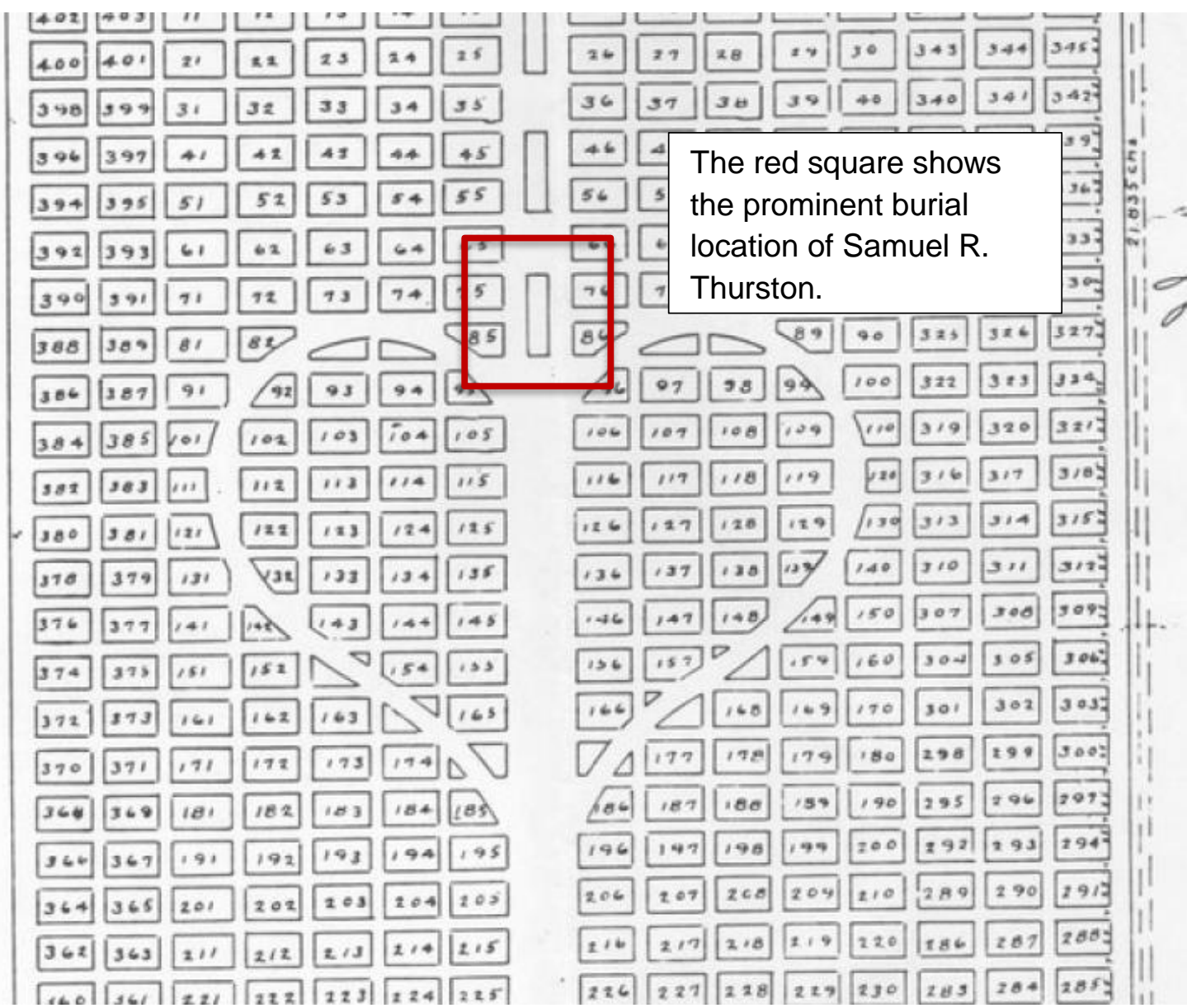

Figure 11: Detail of 1914 Plat map cited in full below. The square denotes the prominent burial location of Samuel R. Thurston.

The relatively small ceremony associated with Thurston's second reburial was unique in terms of reinterment ceremonies around the country at the time and it is possible that the lack of attention had to do with the struggle over the location

\footnotetext{
${ }^{144}$ Mary A. Gray McLench, "Early Day Teachers," Ladd and Bush Quarterly 3, no. 2 (January 1916): 9, accessed online May 21, 2018 via Google Books, https://books.google.com/books?id=264aAQAAMAAJ\&vq=cemetery\&dq=ladd\%20and\%20bush\&pg $=\mathrm{RA} 2-\mathrm{PA} 9 \# \mathrm{v}=$ onepage $\& \mathrm{q}=$ mclench \&f$=$ false.
} 
of the Territory's capital. Cemetery owners and managers often used the reburial of prominent individuals to increase interest and purchase of plots in the cemetery by others. ${ }^{145}$ Thurston's fame and admiration was certainly still large enough just a few years after his death to warrant a grand reburial by the I.O.O.F. to advertise their cemetery to the rest of the valley. However, since Thurston's reburial took place so soon after the suspected arson of the Territorial capital building, legislators may have been hesitant to bring attention to the reburial in fear of starting a discussion of moving Thurston's remains, along with the capital itself, to another location in Oregon. Thurston was buried in Salem because that was the capital of the Oregon Territory and government was his most important contribution to the resettlers of Oregon. The man himself had lived in Oregon City and had no personal ties to Salem. On the other hand, the Odd Fellows' expensive investment in the cemetery indicates a genuine interest in the public good. Maybe there were no political machinations behind Thurston's quiet, second reburial. However, as the trend in America was for boisterous, expensive reinterment, this reburial is unique. Maybe the celebration was not for the promotion of the cemetery but for the city instead, and the city had already had its celebratory reburial of Thurston.

While the Odd Fellows may have skipped the chance to promote their cemetery through an elaborate reburial, the design and name of the cemetery was an explicit call to the very famous rural cemeteries of the East Coast, just like the

145 See Michael Kammen, Digging Up the Dead: A History of American Reburials (Chicago and London: University of Chicago Press, 2010) for a in-depth history of this trend. 
author from the beginning of this chapter wanted. The compiler of the City of Salem 1871 Directory, Lodge-member J. Henry Brown, included a small spotlight on the cemetery that stated: "the Cemetery is being beautifully improved by the Order who have it in charge. In after times we hope it will be to Salem as Greenwood Cemetery is to New York - a sweet resting place for her citizens after the toils and cares of life are over."146 If well-developed and successful cities like New York had rural-style cemeteries, Salem ought to have a similar one. Due to this desire to copy the rural design, an odd reversal of philosophy first had to occur. If a rural cemetery is an escape to the wild, what happens when you put a rural cemetery in an undeveloped region?

The rural cemetery of the East was an escape to the wild; in Salem, a rural cemetery meant a well maintained and beautifully landscaped escape from the wild. The maps in Figure 12 show the layout of the Odd Fellows Rural Cemetery and Green-Wood Cemetery in New York. Notice in the Odd Fellow Rural cemetery the heart-shaped lanes that were designed for use by a carriage, and the middle lane which was reserved for the most famous Salem citizens (the top-most, inner square is occupied by lay Methodist missionary member and prominent Salem citizen William H. Willson). These straight lines are very different from Bigelow and Dearborn's original vision for Mount Auburn to meld naturally with the landscape. Even Greenwood, the New York Cemetery that I.O.O.F. was trying to replicate had wavy pathways that contoured with the land instead of shaping it to something as

${ }^{146}$ J. Henry Brown, compiler, The Salem Directory for 1871 (Salem: Snyder \& Cook, 1871), 85. 

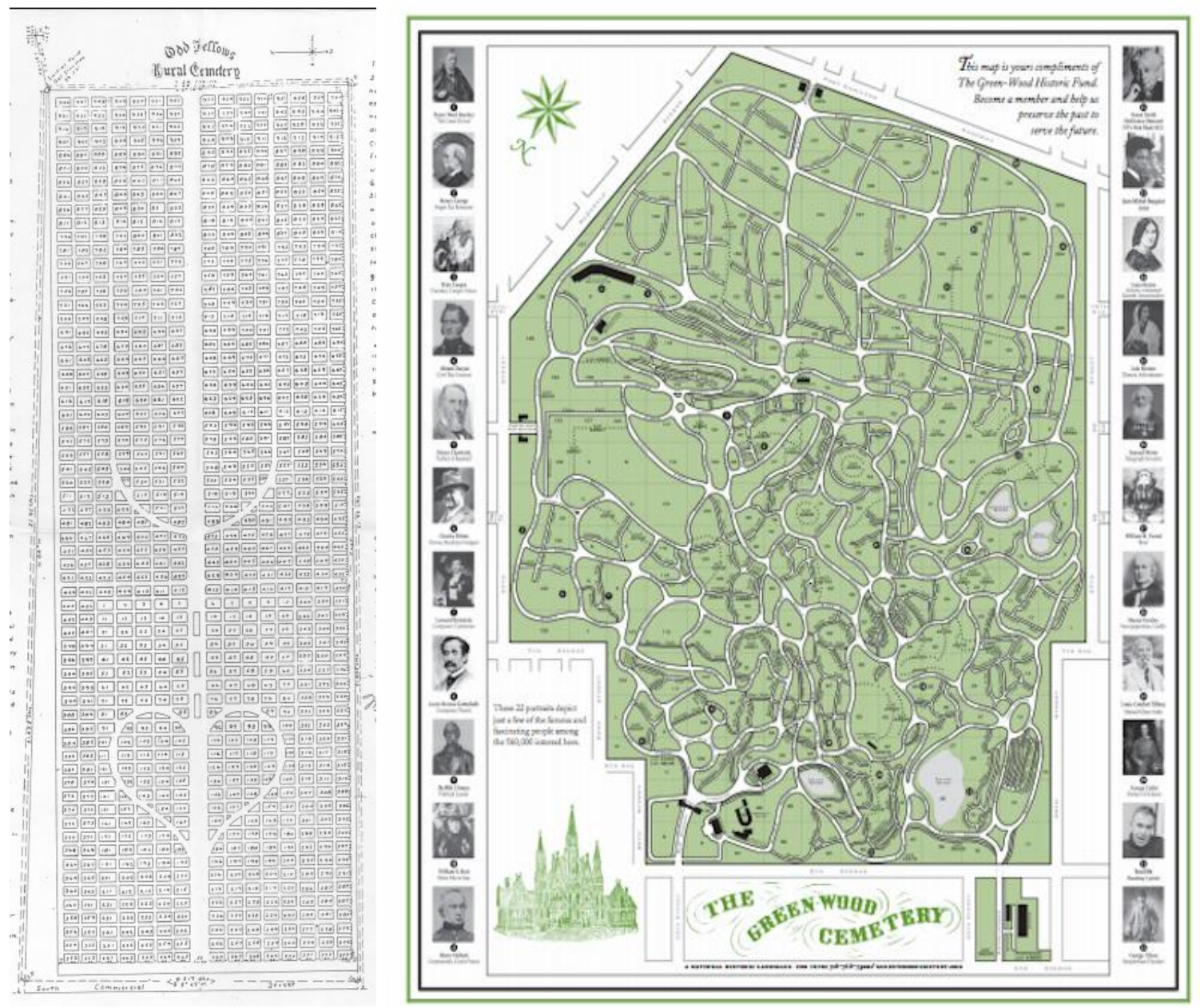

Figure 12: Compare the highly curated lined of the Odd Fellows Rural Cemetery to this map of The Greenwood Cemetery in New York City. Greenwood contours to the natural flow of the landscape while the Salem cemetery looks more like a structured park. Odd Fellows Rural Cemetery Plat, Marion County, Oregon, 1914, as cited in Elisabeth Warren Potter, "Odd Fellows Rural Cemetery," National Register of Historic Places Nomination Form, (Salem, Oregon 2013), 50; Greenwood Cemetery Map, compliment of the Green-Wood Historic Fund.

man-made looking as a heart. This was a rural cemetery, but not in the same sense that Bigelow and Dearborn intended. If someone needed wilderness in 1860

Western Oregon, all they would need to do is ride their horse a half hour in almost any direction to find a forest or a river. In Oregon, a rural style cemetery was not a response to industrialization, it was a marker that industrialization could happen. 
The rural cemetery in Oregon was a middle landscape that functioned as a marker of colonized and settled land, primed for new residents and especially new investors. Over the decades after Congress officially recognized the State of Oregon on February 14, 1859, Salemites experienced a large influx of population. In 1860 , Salem had a population of 902 and by 1870, the population had doubled to 2,139; by 1880, the population leveled somewhat at 2,538.147 Investment in Salem was steady but significant. While many people left after news of the California gold rush reached Salem, some lucky Salemites returned with money to invest in growing commercial, residential, and industrial districts which utilized the unparalleled agricultural and range land that characterized the Willamette Valley. Those who stayed behind also benefitted by providing goods from those very same resources. ${ }^{148}$ By 1870 , the railroad had come, and places like the Thomas Kay Woolen Mill (1889) and the Salem Woolen Mill (1857) employed hundreds of people. ${ }^{149}$ Salem was a great city to live, and more importantly, to invest funds.

As time passed, the cemetery landscape of Salem continued to change; citizens created one new cemetery and witnessed the decline and subsequent repair of the old missionary cemetery east of town. A small Catholic cemetery opened far south on Commercial Street in 1867, but the one-acre cemetery was reserved for

\footnotetext{
147 For comparison, in 1860, Portland had a population of 2,868 people and by 1870 had 8,293 people. Riley Moffat, Population History of Western U.S. Cities and Towns, 1850-1990 (Scarecrow Press, 1996), 214-215.

148 Gail E. H. Evans, "Salem Downtown Historic District," National Register of Historic Places Nomination Form, Evans-Hatch \& Associates, Salem, 2000-2001. 149 Joan Meyering, "Woolen Mills," Salem Public Library, Salem History, 2005, http://salemhistory.net/commerce/wool.htm (accessed August 11, 2018).
} 
Catholic members of the community and had little impact on the burial habits of Salemites as a whole. ${ }^{150}$ While the Odd Fellows and the new Catholic Cemetery were beautified, the same was not true for the old missionary cemetery. In the years since Anna Maria Pittman Lee's reinterment, it had been left in a cyclical state of ruin and repair. In 1869, almost thirty years after the burial of Lucy Thompson Lee, a reporter for The Daily Unionist described the cemetery as "little used of late," and was "now being again improved for public use." ${ }^{151}$ In 1871, the trustees of the Lee Mission Cemetery, A. F. Waller, M. L. Savage, J. L. Parrish, and L. H. Judson (all besides Savage were members of the Methodist mission party), announced that the cemetery was now laid out in plots and could serve as a public burying ground. ${ }^{152}$ However, it seems their work did little to improve the grounds as in 1873 the Weekly Oregon Statesman published a piece about the sad, neglected state of the Lee Mission Cemetery:

In this beautiful burial place are deposited the remains of the FIRST WHITE WOMAN and child, who died and were buried on Oregon soil... It is a sacred spot and one which we should esteem a grand privilege to ornament and protect. But...it has literally gone to RUIN AND DECAY... Is all this right? Have we no respect for the dead? We owe much, very much, to the labors of many of those entombed here. ${ }^{153}$

This article represents the beginning of a shift in the narrative surrounding Jason Lee and the missionary party after the mission disbanded in 1844. Instead of the wife of an opportunistic colonizer, Pittman Lee and her child were martyrs, now

\footnotetext{
150 The cemetery is now reportedly full. "St. Barbara's," Oregon Burial Site Guide, 652.

151 “State News: Salem," The Daily Oregon Unionist, August 19, 1869, p. 2.

152 “Notice. The Lee Mission Cemetery...," Weekly Oregon Statesman, September 6, 1871, p. 3.

153 Emphasis in text, "Mission Cemetery," Weekly Oregon Statesman, August 19, 1873, p. 1.
} 
uncared for and forgotten. As this focus on Lee and his party intensified, the scope expanded from the dilapidated state of the Lee Mission Cemetery to include the forgotten remains of Jason Lee himself, left lonely and obscure, far away from his realm of greatest influence.

During the late nineteenth and early twentieth centuries, two intersecting forces met and began swirling around the remains of Jason Lee as a fitting symbol of their overlapping focus: first, anxiety about death and the decline of the economy in the 1870s-1890s which resulted in the intense memorialization of the original round of pioneers; and second, the self-promotion of cities to attract a larger population and more investment. Lee, instead of an embarrassing failure, became a celebrated figure of colonization - a decided reversal of the narrative that dominated his memory in previous decades. The cemetery named in his honor was a reason to come to and be buried in Salem. It was a chance be close to the person who started it all either in death or life. For Oregon, Lee was a symbol of civilization; in Salem, Lee's remains were also a symbol of modernization.

Anxiety about death and the treatment of the remains of the "original" settlers existed in many facets of Oregon culture during this time. Historian Peter Boag explores the connections between parricide, agricultural decline, and dying pioneers at the end of the nineteenth century. ${ }^{154}$ In the 1870 s, there were two forces that contributed to this anxiety about death: the decline of agricultural prices and

\footnotetext{
154 Peter Boag, “Death and Oregon's Settler Generation: Connecting Parricide, Agricultural Decline, and Dying Pioneers at the Turn of the Twentieth Century," Oregon Historical Quarterly 115, no. 3 (Fall 2014), p. 344-379.
} 
the ever-growing list of deaths of Oregon's original pioneers. This intersection created a kind of "cultural crisis evident in the fixation on, embellishment of, and memorization of pioneers and their demise."155 In 1873, the founding of the Oregon Pioneer Association coincided with a financial panic that caused a depression in both North American and Europe. By the 1890s, this intense focus on memory increased in the wake of a depression that wreaked havoc on the agricultural profits of settlers across Oregon. In 1877 , a bushel of wheat netted $\$ 1.11$, by 1895 , the price was a mere 47 cents. ${ }^{156}$ Two groups focused on preserving memory, the Oregon Historical Society and the Native Sons and Daughters, formed during the late 1890s. Within this context, it is not a surprise that an effort to reinter the remains of Jason Lee arose in the next decade. A reinterment at a proper cemetery fit perfectly into this tendency as a physical way to honor someone's memory. This comingled atmosphere of anxiety and death galvanized movements aimed at the intense memorialization of tragic figures like Jason Lee, Anna Maria Pittman Lee, Lucy Thompson Lee, and others like Marcus and Narcissa Whitman. 157

Not everyone in Oregon was supportive of this movement to commemorate the old pioneers. One of Oregon's most famous still-living pioneers at the time,

\footnotetext{
155 Boag, “Death and Oregon's Settler Generation," 349.

156 Boag, "Death and Oregon's Settler Generation," 346.

157 The Whitman Mission ended in 1847 after members of the Cayuse tribe killed the missionaries. While often sensationalized, especially around the turn of the nineteenth-century, current scholarship is working to provide a more nuanced interpretation of the event. For a short introductory, see Cameron Addis, "Whitman Massacre," The Oregon Encyclopedia, entry last updated May 21, 2018, accessed June 3, 2018, https://oregonencyclopedia.org/articles/whitman massacre/\#.WxRWdUgvw2w and "The Missionary Era," History of the CTUIR, Cayuse - Umatilla - Walla Walla, Confederated Tribes of the Umatilla Indian Reservation, (no date), accessed June 3, 2018, http://ctuir.org/historyculture/history-ctuir.
} 
Lindsay Applegate, was openly disdainful towards Jason Lee. Applegate, described in the 1890 newspaper article as a "brave old patriarch," was the brother of Jesse Applegate of Applegate Trail fame, and one of the first white resettlers to the Umpqua Valley in southern Oregon. The unnamed interviewer found Applegate at home, with "spectacles on his heroic nose, which [stood] out prominently like the beak of a veteran war eagle." 158 Applegate was critical of those trying to memorialize Lee: “Oh, this Jason was a protestant missionary to Oregon. He got a crowd of white-eyed followers in Boston in '41 and came by water around Cape Horn. He jiggered around, trading for fur the clothes he had begged for the heathen and then sold the furs to the Hudson Bay company."159 According to this old pioneer, Lee was not worthy of the admiration directed his way. It seems that there were enough people who agreed with Applegate's interpretation of Lee in the 1890s that it took about ten years for any real effort to change the narrative of Lee's work and in turn, memorialize his colonization efforts.

This effort to change Lee's story coincided with the pattern of promotion which many cities on the West Coast used to sponsor increased population growth

\footnotetext{
158 "The Pathfinder Talks," Oregon Statesman, August 31, 1890, p.7. Applegate also held contempt for those who had earlier tried to memorialize the Whitmans: "I don't understand the motives and follies of the East... and fail to appreciate either. It took the evidence of all the old settlers to knock down that Whitman monument foolishness, and why they were so eager to stick up an everlasting reminder of HIM, I cannot see. If they had stuck it up is should have written on it a mournful epitaph in memory of the loss of the good horse sense that lived and flourished in the East in the early days of New England."

${ }^{159}$ According to the Oxford English Dictionary, "jigger" was a "vague substitute for a profane oath." See "jigger, v.2," OED Online, Oxford University Press (March 2018), accessed June 3, 2018, http://www.oed.com.proxy.lib.pdx.edu/view/Entry/101283?rskey=90xub3\&result=4\&isAdvanced= false; ibid.
} 
and investment. On January 1, 1901, the editors of the Oregon Statesman started a tradition of publishing the "New Year Edition" of the paper which celebrated the successes of Salem's residents during the previous year. The edition included essays about the status of agriculture, services like schools and churches, economic activity, and the homes of prominent residents of the city. Some of the headlines boasted phrases such as "Agricultural Development of the Great and Wonderful Willamette Valley," “An Ideal Dairy Country," and "Salem, The Capital City of Oregon: Built on Historical Ground in the Beautiful Willamette Valley - It is an Ideal Home City."160 An author, likely editor of the Statesman at the time, R.J. Hendricks, described Salem as the "result of a steady growth dating back to 1837 when Rev. Jason Lee ... selected a mission site near the city." He continued "in 1841 the school was removed to Salem because of its beautiful location and from that year the settlement was permanent... The increase in population has been constant and the commercial growth of the city never at a standstill."161 This quote indicates that Lee was becoming central to the story of Salem and the Willamette Valley. In 1901, the author claimed the infrastructure set up by Jason Lee and the missionaries - sixty years previously at the time of the special edition's publication - as one of the reasons Salem was so well-developed.

The remains of central cultural figures also added to Salem's importance and prestige. In 1903, editors of the Statesman dedicated almost an entire page to the

\footnotetext{
160 “New Year Edition," Daily Oregon Statesman, January 1, 1901, whole edition. 161 "Salem, The Capital City of Oregon: Built on Historical Ground in the Beautiful Willamette Valley It is an Ideal Home City," Oregon Statesman, January 1, 1901, p. 5.
} 
sermon of Rev. John Parsons. In the sermon, titled “The Consecrated Tree," Parsons spoke about a tree located in the Jason Lee cemetery, "the most religiously romantic spot on the Pacific Coast."162 Parsons noted the famous burials there: Father Parrish, Cyrus Shepard, Anna Maria Pittman Lee, Alvan P. Waller, among others. He described how these famous missionaries welcomed death as a "voyage from the port of time to the quiet haven of eternity," a way to be forever with God.163 Photos of prominent religious men, like Bishop J. W. Hamilton, at the Jason Lee cemetery accompanied the sermon. Hamilton was in Salem for the Methodist Conference and visited this important religious location while he was in town. However, this visit "disclosed the fact, which was a surprise to many of the party, that though the cemetery is the oldest in the state and is named after Jason Lee, the remains of that valiant pioneer in missionary work in Oregon were buried in Canada." The author of the article continued by explaining that it was "not generally known that Jason Lee died in Canada and was buried in his native town." Without mentioning the fact that Lee was stripped of his title as superintendent, the author gave a short history of the famous missionary, simply saying that "in 1843 it again became necessary for some representative of the Mission to go East."164 With this context, it is no surprise that the attendees at the next year's Methodist Conference adopted a resolution to bring Lee's remains to Salem.

\footnotetext{
162 Rev. John Parsons, “The Consecrated Tree," printed in the Oregon Statesman, October 11, 1903, p. 2. 163 Ibid.

164 “Rev. Jason Lee," Oregon Statesman, December 27, 1903, p. 2.
} 
Oregonians from all over the state quickly embraced the mission to bring Lee's remains west. Esther Magee French, a native of Jason Lee's birthplace (Stanstead, Vermont) and a settler in The Dalles in 1877, is credited with proposing the resolution that the Columbia River Conference of the Methodist Episcopal Church adopted in 1904 to return the remains of Jason Lee to Salem. ${ }^{165}$ In early 1904, she wrote to Col. Frederick D. Butterfield, of Derby Line, Vermont, and suggested removing Lee's remains to Oregon. In response, Col. Butterfield agreed to fund the endeavor. ${ }^{166}$ She presented the idea at the 1904 Methodist Conference and they agreed to support the resolution. As reported in the Eugene Morning Register, on the fourth day of the 1904 conference a movement was "on foot to bring to Oregon for final burial the body of the famous missionary, Jason Lee... A committee

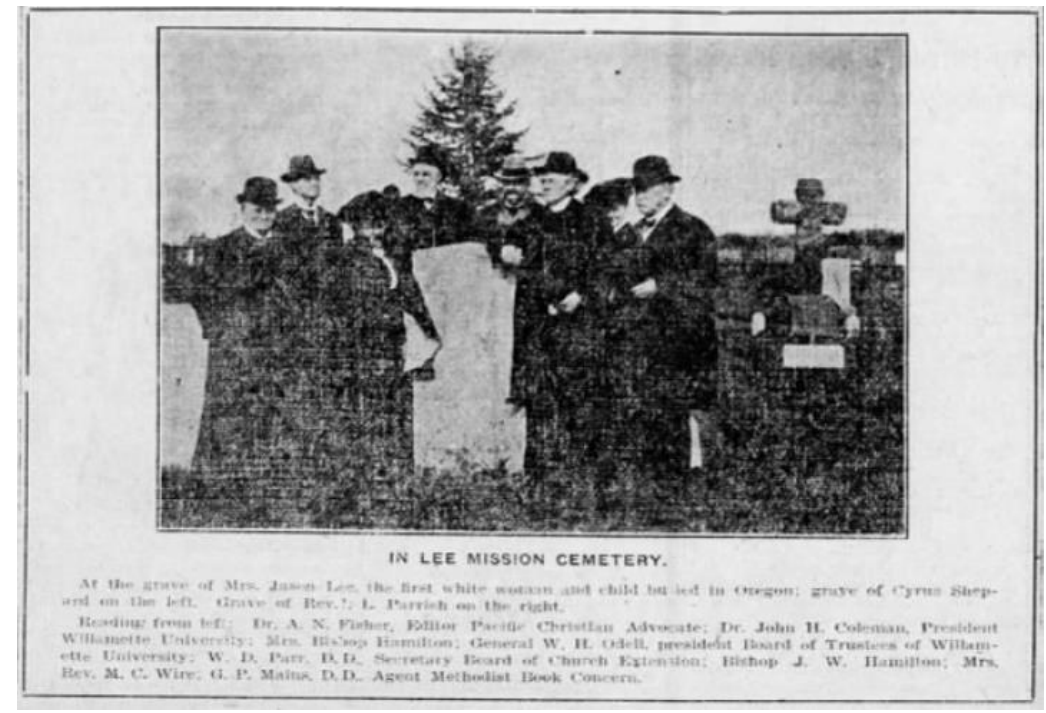

Figure 13: Bishop J. W. Hamilton at the Lee Mission Cemetery. Oregon Statesman, October 11, 1903

\footnotetext{
165 Elisabeth Warren Potter, Remembering Oregon's missionary pioneer : the story of Jason Lee's reinterment in Lee Mission Cemetery, Salem, Oregon (Salem: Jason Lee Cemetery, 2006), 11. 166 "Movement to Re-inter Remains," Memorial Services at Re-interment of Remains of Jason Lee, Memorial Souvenir Jason Lee, (Salem, 1906), 2, available in Cemetery Subject file, Willamette Heritage Center Archive and Research Library (WHC), Salem, Oregon.
} 
was appointed for furthering this enterprise."167 The members of the committee were from both the Oregon Conference and the Columbia River Conference. Some of the names included: Mr. A. M. Smith (Oregon), President of the Board of Trustees of Willamette University; Rev. Dr. Coleman (Oregon), President of the University; Mrs. Smith French (Columbia River), The Dalles; and Mr. Robt. A. Booth (Columbia River), The Dalles. ${ }^{168}$ This wide range of committee members shows the commitment from across the state to celebrate the remains of Jason Lee.

Reports of the effort were almost universally lauded. In Salem, reporters made sure to mention the influence of Jason Lee over the entirety of the Pacific Northwest: the reinterment was a "a step that should be been taken a great many years ago in justice to a great man, and one whose labors made possible much of the greatness of not only the Methodist Church in this state, but of all of that great territory at one time known as the Oregon Territory, but now comprising all the of the states of Oregon, Washington, Idaho and part of Montana."169 Just the next day, the Statesman published a small piece which called for the Methodist church to receive the "commendation of every citizen of Oregon." 170 The reinterment was a celebration of the complete colonization of Oregon, a process which Jason Lee himself started, and for what he was once condemned for by his contemporaries.

The narrative surrounding Jason Lee and the Methodist mission in Oregon was now almost completely reversed from the previously dominant narrative of Lee

\footnotetext{
167 “To Bring Jason Lee's Body to Coast,” Eugene Morning Register, October 2, 1904, p. 4.

168 Ibid.; "Movement to Re-inter Remains," Memorial Souvenir Jason Lee, 2.

169 "Will Bring Remains Here," Oregon Statesman, October 5, 1904, p.1.

170 "For deciding to have the remains...," Statesman Journal, October 6, 1904, p. 2.
} 
as an insincere opportunist. The East Oregonian in Pendleton printed a piece about the reinterment efforts that asked the readers to "recall the condition in the Oregon territory in 1834," so they "would fully understand the heroism that was necessary." The reinterment in Oregon, "the land he helped to save to the United States, [was] a fitting close for the chapter of history comprised in his self-sacrificing and heroic life." 171 A similar reprint of the article in Salem, though rather dramatically re-titled "Hardships of Rev. Jason Lee," painted the Methodist as a brave and intrepid missionary, dedicated to his task and recognizing it as his place to "awaken the east to the needs of the young empire of the west."172 Gone was the Lee of Applegate's memory. This Lee was a hero to Oregon, and a proper reinterment the greatest honor Oregonians could give him.

The organization of this effort was quick, and Lee's remains arrived in Portland in late November 1904, though Salem's Jason Lee Cemetery was not quite ready to receive them. They were placed in a safety-deposit box located at the Chamber of Commerce Building until a proper ceremony could be arranged. F. H. Grubbs, the husband of Lee's only surviving child, Lucy Anna Maria Lee (Grubbs), was tasked with caring for the remains during transit. ${ }^{173}$ Lee's tombstone, which had lain at the head of his Canadian grave for nearly sixty years, was also transported to Oregon and held at the train depot for a short time. ${ }^{174}$ In August of 1905, a reporter for the Oregon Statesman announced that arrangements were

\footnotetext{
171 “Welcome, Jason Lee," East Oregonian, November 30, 1904, p. 4.

172 “Hardships of Rev. Jason Lee," Daily Capital Journal, December 3, 1904, p. 6.

173 “Body of Jason Lee Here,” Morning Oregonian, November 29, 1904, p. 14.

174 "In bringing the body of Jason Lee," Oregon Statesman, December 13, 1904, p. 4.
} 
being made to beautify the cemetery in anticipation of the event. Mr. Litchfield, President of the board of trustees took the "matter in hand" and believed everything would be in order by September, when the Methodist Conference would meet. ${ }^{175}$ The conference attendees, however, decided to push back the reinterment ceremonies to the next year to coincide with commencement of Willamette University, strengthening the connection between Lee and university that developed from his first efforts to create a school for the children of resettlers in the valley. ${ }^{176}$

According to the subsequent reports, the reinterment ceremony in June 1906 was moving, elaborate, and well-attended, just as the planners intended. There was a morning service done by the Church, an afternoon hosted by the Pioneer Association, and evening service under official State auspices. ${ }^{177}$ Just as Lee had near sixty years previously, the planners of the event separated the secular from the religious. Men of renown gave speeches morning until night. Harvey W. Scott, editor of the Portland Oregonian, spoke during the afternoon session of the service: "On this view the work of our missionaries in Oregon rises to proportions more and more majestic, as we study it from the viewpoint of history and of consequences; and though others bore lofty spirits and did great work, no name stands or will stand above that of Jason Lee."178 The actual interment took place between the

\footnotetext{
175 "To Improve Cemetery," Oregon Statesman, August 4, 1905, p. 4.

176 “Tribute to Great Pioneer," East Oregonian, June 4, 1906, p. 5.

177 "Program," Memorial Souvenir Jason Lee, 3-5.

178 Cornelius J. Brosnan, Jason Lee: Prophet of the New Oregon (New York: Macmillan, 1932), 328329.
} 
afternoon and evening sessions of speakers. Pall Bearers included both former governors Z. F. Moody and T. T. Geer. Here, Jason Lee's role as colonizer was not an embarrassment, it was the reason to celebrate him: "the work that [Lee] did to colonize the country with American citizens under the trying difficulties of the situation proved of incalculable value... Jason Lee was a remarkable man - of great determination and wonderful foresight, but like others of the great benefactors of his race, he was not understood in his time. Through ignorance of the situation, his church dismissed him from the control of its affairs here, most unjustly and cruelly... His vindication has come."179 Other eulogies echoed this sentiment and many gave attention to Lee's motives in Oregon, continuing an academic debate which persists to modern times. Lee was lauded alongside names like John McLoughlin (ironic because the Lee and McLoughlin eventually came to fight over the valuable land claim at the Willamette Falls, causing McLoughlin to lose almost all his fortune and his job), the Whitmans, and other prominent early resettlers of the Oregon Country. ${ }^{180}$ Committed to the memory of this second generations of "pioneers," and to the historical record, Lee was now the first and most important colonizer of the Pacific Northwest.

Remembering Jason Lee in a positive light, despite his failings as a missionary leader, was both a natural human impulse and a useful way to embrace

\footnotetext{
179 “Eulogy of Hon. J. C. Moreland," Memorial Souvenir Jason Lee, 9.

180 For a brief survey of the fight over Willamette Falls, see Joshua Binas, "McLoughlin Land Survey Claim, 1843," The Oregon History Project, 2006, accessed June 3, 2018, https://oregonhistoryproject.org/articles/historical-records/mcloughlin-land-survey-claim1843/\#.WxTNw0gvw2w.
} 
closure despite the moral implications of the colonization of Indigenous land. Sigmund Freud, in Reflections on War and Death (1918), commented on the human tendency to temper memory: "we assume a special attitude towards the dead, something almost like admiration for one who has accomplished a very difficult feat." He continues, "We suspend criticism of him, overlooking whatever wrongs he may have done, and issue the command, de mortuis nil nisi bene: we act as if we were justified in singing his praises at the funeral oration, and inscribe only what is to his advantage on the tombstone. This consideration for the dead ... is more important to us than the truth." Historian Matthew Dennis elaborates: "Having fulfilled the obligations of eulogizing pioneers, Oregonians could embrace closure - that is, respect-able forgetting - and give themselves permission to focus guiltlessly on the future." 181 The reinterment of Jason Lee was the perfect way for Oregonians to pass the onus of colonization on to the earlier generation, but with all the proper commemoration and ceremony.

The reinterment of Jason Lee received attention in the news in many parts of the country. The Janesville Daily Gazette of Janesville, Wisconsin features the headline "Body of Oregon Pioneer Reinterred with Honors."182 Editors feature similar headlines in the Palestine Daily Herald of Texas, the Grand Forks Herald of North Dakota, the Coffeyville Daily Journal of Kansas, and other states. This was the

\footnotetext{
${ }^{181}$ Matthew Dennis, "Natives and Pioneers: Death and the Settling and Unsettling of Oregon," Oregon Historical Quarterly 115, no. 3 (Fall 2014), 288.

182 "Body of Oregon Pioneer Reinterred with Honors," Janesville Daily Gazette [Wisconsin], June 15, 1906, p. 1.
} 
biggest story coming out of Oregon, and proof of its full colonization and settlement to the rest of the world.

In addition to the transformed memory of Jason Lee that arose from this reinterment, the exalted memory of his wives, treated almost as the sacrificial lambs of American expansion, highlights the complexities of gender around the turn of the century, especially when reconstructing a narrative that showed the women in their best light. Anna Maria Pittman Lee and Lucy Thompson Lee were the center of some of Oregon's most tragic and celebrated twentieth-century stories. Both died during childbirth in service of God and Jason Lee. Cast as perfect women, their selfsacrificing, God-fearing natures and their tragic deaths at young ages turned them into martyrs of the Oregon Country. This quote from the Memorial Souvenir of reinterment is an example of some of the exaggerated language that is often associated with them:

The Diamond Square [the center of the Jason Lee Cemetery where the most important missionaries are buried] is enclosed by an iron railing and within its precincts lie 'in each other's arms, and clasped to the bosom of the earth, which they came to rescue from Paganism, two sisters of Christ, the companions of a heroic soldier of the cross, having laid down their lives while darkness was yet on the face of the deep, when no church spire glistened in the mellow sunlight of the Willamette -- fallen one after the other, at the dawn of a glorious civilization to sleep under the melancholy dirges of the wilderness. ${ }^{183}$

The story of Anna Maria Pittman Lee is especially "romantic" since she was the first white woman to die and be buried in the Oregon Country. Reporters and lay

\footnotetext{
183 There is a quote in this paragraph within the memorial book but the original source of this quote
} is unclear. "Lee Mission Cemetery," Memorial Souvenir Jason Lee, 58. 
historians often tell her story in entries about the early Oregon Country. ${ }^{184}$ Her

death is almost treated as a necessary sacrifice, needed to ensure the proper settlement of the land by her Protestant followers. ${ }^{185}$

Another story about Pittman Lee that also emphasized the importance placed on the remembrance of her remains is the trial of securing her gravestone, quite the noble odyssey by early accounts. After word of Anna Maria's death reached Lee back East, he arranged for a gravestone to be carved which would eventually make its way back to Oregon on the Lausanne, accompanied by a returning Lee and his new wife, Lucy Thompson. ${ }^{186}$ The epitaph, in part, read "Beneath this sod, the first ever broken in Oregon for the reception of a white mother and child, lie the remains of Anna Maria Pittman wife of Rev. Jason Lee, with her infant son." This excerpt, written by Statesman editor R. J. Hendricks, emphasized how far the stone had travelled, just as Anna Maria had when on route to the mission originally:

\footnotetext{
${ }^{184}$ See for some examples "Day Devoted to Memory and Honor of Jason Lee," Daily Oregon Statesman, June 16, 1906, p. 4; "Marion County Contains Burial Places of Early Pioneer of the West, Historic Cemetery to be Found in This County," The Oregon Statesman, May 30, 1926, p. 1; Theresa Gay, Life and Letters of Mrs. Jason Lee (Portland: Binford \& Mort, 1936); Syliva Mattson, Missionary Footpaths: The Story of Anna Maria Pittman Lee (Mrs. Jason Lee) (Salem: Mission Mill Museum, 1978); Vera Joyce Nelson, "Anna Maria Pittman Lee," in Helen Krebs Smith, ed., With Her Own Wings: Historical Sketches, Reminiscences, and Anecdotes of Oregon's Pioneer Women (Portland: Beattie and Company, 1948).

${ }^{185}$ At the Oregon Centennial Celebration, there was a historical pageant which recreated the weddings of Jason Lee and Anna Maria Pittman Lee and Cyrus Shepard and Susan Downing in Oregon. See "Oliver Huston and Mrs. Otto Paulus portraying Jason Lee and his bride, Anna Marie Pittman, in Salem, Oregon Centennial celebration, 1940," (photo), Ben Maxwell Collection, ID184, Salem Public Library, Salem, Oregon, accessed October 3, 2018, http://photos.salemhistory.net/cdm/singleitem/collection/max/id/443/rec/4. For an analysis of the more well-known phenomenon of the violent recreations of the killing of another famous missionary, Narcissa Whitman, see Chelsea K. Vaughn, "Killing Narcissa: Race, Gender, and Violence in Recreations of the Whitman Incident," Oregon Historical Quarterly 115, no. 3 (Fall 2014): 380-413. ${ }^{186}$ Brosnan, Jason Lee, 151.
} 
The grave stone in question, landed June 1,1840, at old Fort Vancouver from the vessel Lausanne, that had carried it some 13,000 miles, around Cape Horn, was transferred to a boat on the Columbia river, to be brought up the Willamette to the old mission 10 miles below the site of Salem; of course a row boat, manned by Indians, and a portage of its cargo made around the Willamette falls at what became Oregon City. A little further up, in the rapids near what became New Era, the boat was overturned, and the grave stone went to the bottom of the Willamette river. It was afterward recovered, and brought on up, the writer surmises, first to the old mission 10 miles below the site of Salem, and, later, to its present location, on the removal of the mother and child. 187

Both Anna Maria and the stone were from distant lands, both destined for some disaster, and both survived in some form or another to the modern day. ${ }^{188}$ The celebrated reinterments of individuals like Jason Lee and Samuel L. Thurston is especially stark when compared to the burials and memory of those who held less well-respected positions in early Salem life. In addition to the Indigenous children of Lee's mission school, those who died during their stays at the Oregon Insane Asylum (now Oregon State Hospital) were also ill-treated in death. ${ }^{189}$

\footnotetext{
187 R.J. Hendricks, “Bits for Breakfast," Oregon Statesman, June 2, 1934, p. 4.

188 In 1976, caretakers of the Lee Mission Cemetery replaced the original markers after it was severely damaged by vandals. The original gravestone was considered lost for some time until it was recently re-discovered stored in the rafters of the Willamette Heritage Center in Salem. See Alfred C. Jones, "Anna Lee to get her headstone back," Capital Journal, June 28, 1976, p. 11 and Mimi Stang, "Found!," Lee Mission Cemetery Newsletter, June 2014, Lee Mission Cemetery, Salem, Oregon, accessed October 3, 2018, http://leemissioncemetery.com/news June_2014.pdf.

189 There are other groups of people who did not receive their just attention after death in Salem but are not highlighted in this paper: A Chinese shrine which was used by Chinese residents in Salem circa 1890 fell out of use by the 1930s and was repeatedly "lost" (covered by bushed and brambles) by Salem Park Employees in the following decades. Sometime in the 1970-80s, the shrine was intentionally destroyed. Research is ongoing. See informational website for the Chinese Shrine at the Salem Pioneer Cemetery here: "Chinese Shrine at the Salem Pioneer Cemetery," Salem Pioneer Cemetery Chinese Shrine Advisory Committee, organized by City of Salem Historic Preservation Department, 2017-2018, accessed October 3, 2018, https://sites.google.com/view/salem-or-chineseshrine/home. For information about the marker placed at the Salem Pioneer Cemetery to honor the more than forty Black pioneers initially buried in the cemetery without a marker, see "Pioneer
} 
The history of mental health is a popular topic in Oregon, largely because of the reputation of mental health institutions in the state, as well as the national attention the 1975 film One Flew Over the Cuckoo's Nest - based on the 1962 novel written by famed Oregonian writer Ken Kesey and filmed at the Oregon State Hospital brought to the state. Contributing to the fascination with mental health in the state is the dark reputation of places like Fairview Training Center (formerly named the Oregon State Institution for the Feeble Minded), located in Salem and which eventually closed in 2000 after a federal investigation. This dark reputation was earned: the center administered thousands of forced sterilizations and former residents recount stories of "discipline with leather cuffs, cow whips, razor straps and isolation cages."190 The residents' remains fared little better. The Oregon Burial Site Guide reports that after the site opened in 1909, burials took place somewhere on the land for several years. The place of these burials, or if they were ever disinterred, is lost to memory. ${ }^{191}$ The story of the remains of those at the Oregon State Hospital is similarly mysterious and sad.

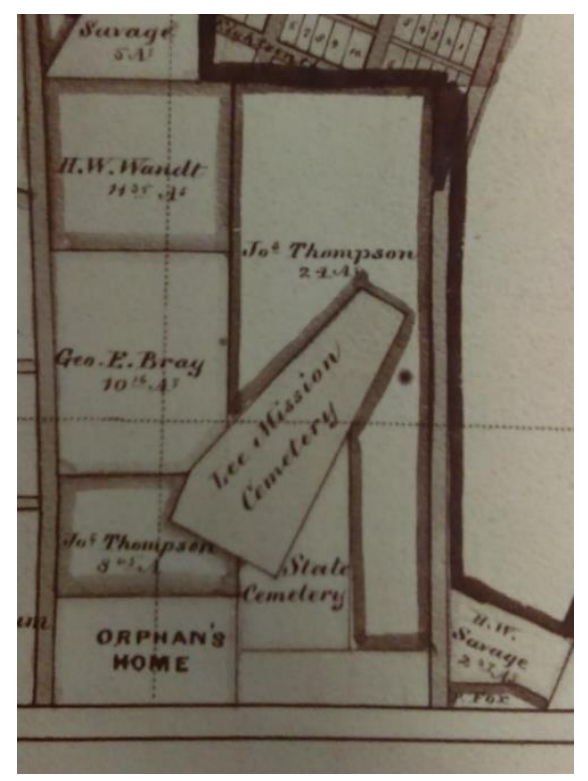

Figure 14: Detail from c1900 map of Salem. See footnote 192.

Cemetery Advocates," Oregon Black Pioneers, 2007, accessed October 3, 2018, http://www.oregonblackpioneers.org/blog/about/pioneer-cemetery-advocates/. 190 Sara Gesler, “Erasing Fairview’s Horrors," Oregonian, January 30, 2010, accessed July 23, 2018, http://s.oregonlive.com/OjIRasd. 191 Byrd et al., Oregon Burial Site Guide, 648. 
When the Oregon State Insane

Asylum opened in Salem in 1883, there

were already two cemeteries located to

the north of the original campus and

there has been confusion between the

sites ever since. ${ }^{192}$ The Jason Lee

Cemetery was located about a half mile

northeast from the main building. The

other cemetery belonged to the Glen

Oaks Orphans Home, erected by the

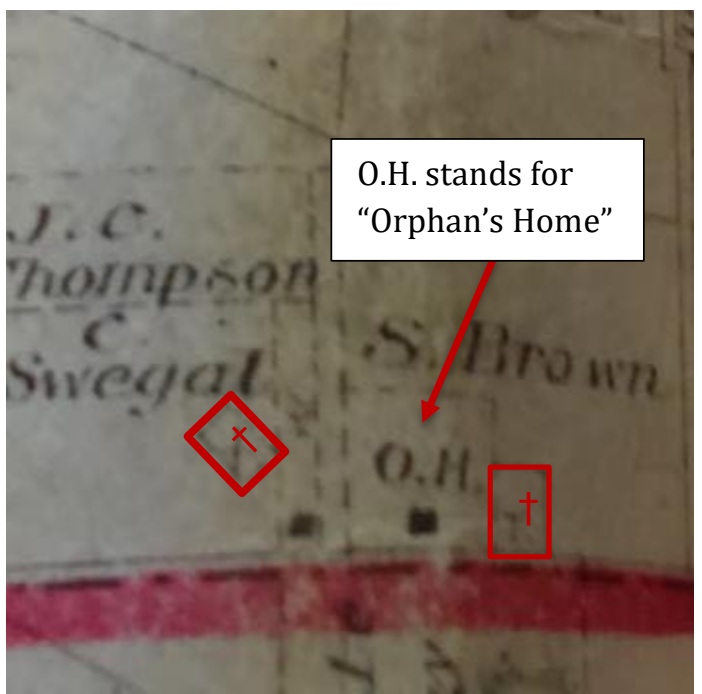

Figure 15: Crosses denote cemeteries on this detail from an 1878 map of Salem. Detail from Edgar Williams \& Co., "Illustrated Historical Atlas Map, Marion and Linn Counties, Oregon," 1878, map number four, p. 40 .

"ladies of the Children's Aid Society" in 1869 on land donated by the same family

who donated the land for the Lee Missionary Cemetery - J. L. Parrish and his wife, Elizabeth Winn Parrish. ${ }^{193}$ There were also accounts of a "State Cemetery," which was probably established after the orphan cemetery and may have eventually subsumed it. There is some confusion between these cemeteries, even in contemporary maps, so the exact location of these three cemeteries is now impossible to identify, but they were all within a few hundred feet of each other northwest of the Oregon State Hospital's main campus. In 1899, the Children's Aid Society, due to the withdrawal of state funding, abandoned the Glen Oaks

\footnotetext{
192 Evidence is from this undated map, circa 1900, found glued into the back cover of the Salem Public Library's copy of Edgar Williams \& Co., Historical Atlas Map, Marion and Linn Counties, Oregon (San Francisco: Edgar Williams \& Co., 1876).

193 “Glen Oaks Orphan's Home," Albany Register, July 17, 1869, p. 3.
} 
Orphanage. The board deeded

the land and the building to the

Salem Hospital which, upon

raising enough funds, renovated

the building to serve as the new

hospital site. ${ }^{194}$ What became of

the orphans' burial ground

during this transfer is unclear.

Just one year before the closure

of the home, the Oregon

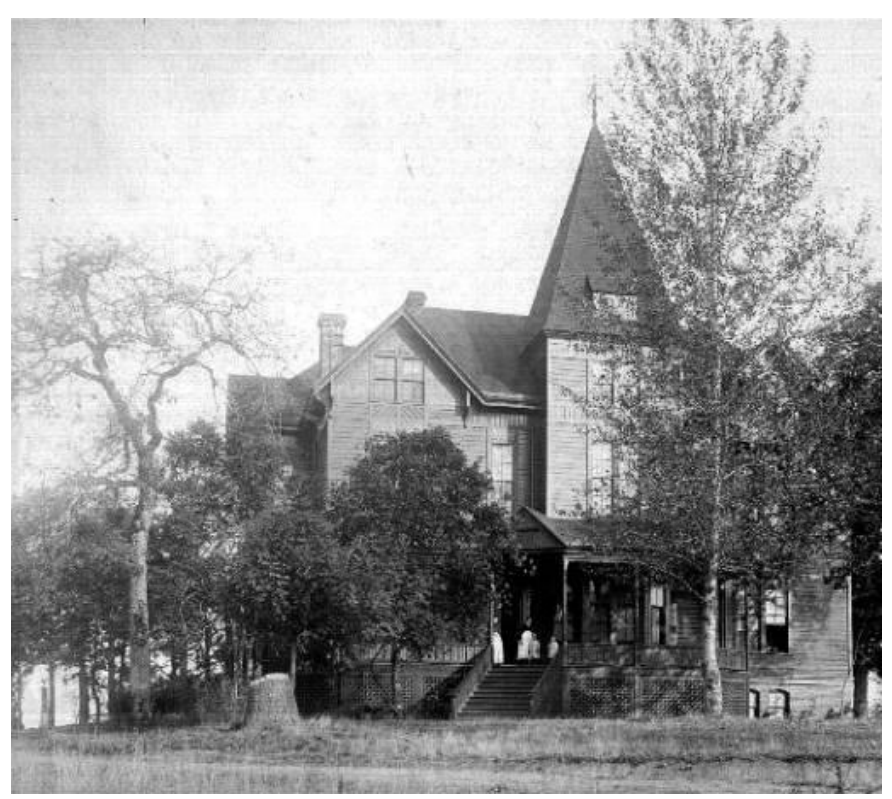

Figure 16: Glen Oaks Orphans' Home as it appeared in 1892. Oregon State Archives, Secretary of State, 0AE0011

Statesman reported a little girl named Winnifred who was "interred in the cemetery plot of the Home," so there was some separation between the sites at that point. ${ }^{195}$ Since maps show the Orphan's home right next to the state cemetery, the most likely explanation is that the "State Cemetery" and the "Orphan's Cemetery" eventually became the same cemetery.

On May 3, 1912, the state legislature considered a bill to establish a crematory at the State Hospital because of both cost and concern over the lack of space in the cemetery. Authorities pointed out "that the cemetery [at the hospital] with 1500 inmates already buried was filling up rapidly at a rate of 150 interments yearly." 196 In 1913, the state went ahead with the investment and purchased a

\footnotetext{
194 "It will be closed," Oregon Statesman, July 7, 1899, p. 5; "Will be a fine home," Oregon Statesman, July 12, 1900, p. 2.

195 “Winnifred, the little 4-months-old charge...," Weekly Oregon Statesman, October 28, 1898, p. 3. 196 "Salem 44 Yrs. Ago," Capital Journal, May 3, 1956, p. 4.
} 
crematory to serve those who died while under the care of the hospital and other state institutions like Fairview. Local newspapers started running notices alerting citizens that they should collect their family members' remains and grave markers if they did not want them to be cremated or the markers to be disposed of. The land was to become a "farm or orchard" after the bodies were exhumed. ${ }^{197}$ The Capital Journal reported that "most inmates of all the state institutions who die from now on, especially those who die from infectious diseases, will be cremated."198 State workers disinterred the bodies and deposited the now un-needed markers in a remote place on state land. It is unclear what happened to the bodies of the orphans from Glen Oaks. The most likely scenario is that they were included in the state disinterments, but this remains unconfirmed.

Evidence of mismanagement of the remains, the cemetery, and the subsequent removal is found in the treatment of the headstones of those who were originally buried in the State cemetery. In January of 1959 , workers preparing land for a new state correctional institution discovered what seemed to be an old, forgotten, and extensively vandalized cemetery "in a wooded area on a bluff behind the Institution."199 The superintendent, Paul J. Squier, said the cemetery "was a complete surprise to him," indicating that institutional knowledge of the fate of the early patients of the hospital had faded. ${ }^{200}$ A spokesman for the hospital incorrectly assumed that the cemetery belonged to a nearby Cottage Farm, an annex of the state

197 “The system of using a crematory...," Daily Capital Journal, April 17, 1913, p. 18.

198 "Will exhume bodies and cremate them," Capital Journal, March 3, 1913, p. 6.

199 "Old Cemetery Found at Correctional Institution," Oregon Statesman, January 16, 1959, p. 1. 200 Ibid. 
hospital. Squier, in an attempt to right a supposed wrong, went about resetting the stones and contemplated holding a ceremony to re-sanctify the area. However, further investigation revealed that under the supposed tombstones was "only a thin layer of duff covering untapped bedrock."201 Eventually, the retired State Hospital superintendent, Dr. John C. Evans, recalled the initial removal and informed Squier. Officials in charge during the exhumation were not sure what to do with the tombstones since they were not technically state property and no family members claimed the stones. They decided to dump them on the property several miles south of the city, in case a family member came forward to claim the headstone. ${ }^{202}$ This cemetery that was not a cemetery is simply one of many incidents that demonstrates how forgotten these remain were.

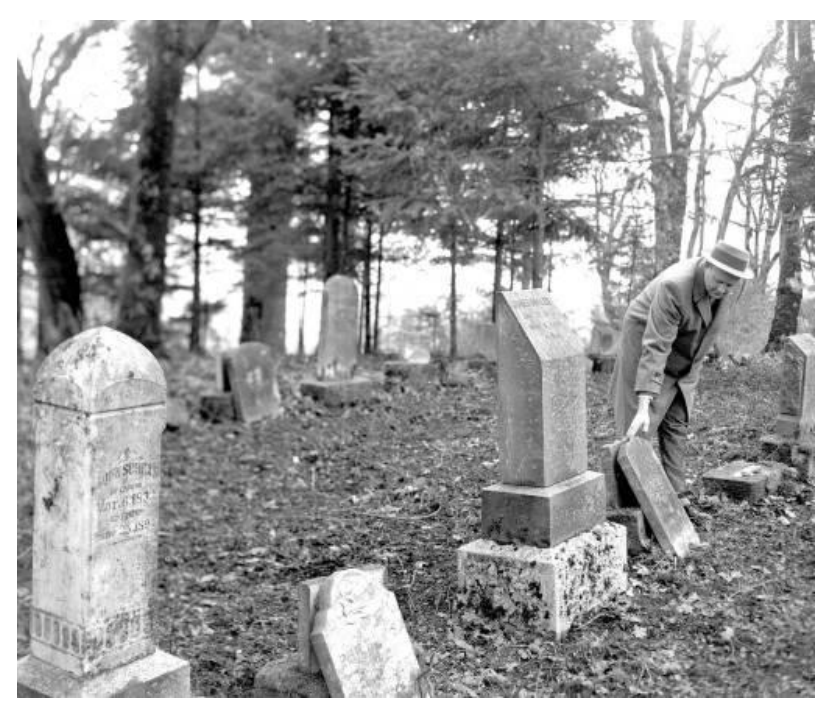

Figure 17: Cemetery that isn't a cemetery at the State Hospital in Salem, Oregon, 1959.

Ben Maxwell Collection, Salem Public Library.

201 Ben Maxwell, “Cemetery Isn't a Cemetery,” Capital Journal, January 23, 1959, p. 1. 202 Ibid, p. 10. 
Unfortunately, tracking down the remains of the patients who were initially buried in the Asylum cemetery is not an easy road to follow. After the patients were exhumed and cremated, the remains that were unclaimed by family members were apparently placed in copper urns and stored in a basement room at the hospital. Other unclaimed remains were added to this room until, in 1964, there were about 3,000 unclaimed remains. Though only required to keep the unclaimed remains for five years, officials continued to care for them. ${ }^{203}$ In 1971, the Oregon legislature passed a law which allowed the State Hospital to contract privately for mortuary services instead of housing their own. That law signaled the end of the copper tins, which, of the 5,132 cremations, 3,809 tins of cremated remained in 1971. Eight years later, in 1979, the state buried the unclaimed remains in a vault where a lily pond had once occupied the land on State Hospital grounds. In 1984, the hospital planned a memorial to honor these former patients. ${ }^{204}$ This effort, while admirable, was not permanent and the remains of these patients would again go through a cycle of care and disrepair.

Despite this attempt to care for the remains of these early Oregonians, fate would again intervene. By the early 2000s, hospital staff discovered that the vaults were leaking from the fountain above and that the water had destroyed the labels; the identities of many of these individuals were now lost forever. Evocative of the state of the entire hospital, the remains signified a long disinvestment in the both

\footnotetext{
203 Scott McArthur, “Ashes of 3,000 Repose at Hospital," Capital Journal, April 23, 1964, p. 1.
}

204 Peggy Sand, “Monument to help mark burial ground," Oregonian, November 4, 1984. 
the hospital and the patients inside. Luckily, for the remains, patients, and staff, a change was finally on the horizon. After consultants deemed portions of the building unsafe in 2005, state officials led by Senate President Peter Courtney approved a $\$ 280$ million plan to rebuild much of the building while retaining the historic Kirkbride building in 2007. The new facility could house 620 patients in modern facilities. ${ }^{205}$ As part of this project, the Oregon Arts Commission designed a memorial to honor the remains of unclaimed patients. ${ }^{206}$ However, after a survey of the remains, hospital staff found that none of the remains belonged to those originally buried in the asylum cemetery. ${ }^{207}$ After nearly one-hundred years, the remains of those who were buried in the asylum cemetery are seemingly missing.

The story of the patients and the remains at the hospital inspired the Oregonian to write a series of editorials, and the coverage of the topic eventually garnered a Pulitzer Prize. This prize was awarded to Rick Attig and Doug for their "persuasive, richly reported editorials on abuses inside a forgotten Oregon mental hospital."208 These editorials investigated both the forgotten remains and the

\footnotetext{
205 Alan Gustafson, "State Hospital Nears Finish of New Facility," Statesman Journal, March 2, 2012. 206 "Oregon State Hospital Memorial Booklet," Oregon Arts Commission, 2012, available online https://www.oregon.gov/oha/OSH/Documents/OSH-Memorial-Booklet.pdf (assessed July 23, 2018).

207 Ian K. Kullgren, “Missing Dead: 1,500 from old Oregon State Hospital cemetery in Salem can't be found," Oregonian, July 3, 2014, available online http://s.oregonlive.com/GhfIBdK (accessed July 28, 2018).

208 "The 2006 Pulitzer Prize in Editorial Writing," The Pulitzer Prizes, accessed November 2, 2018, https://www.pulitzer.org/winners/rick-attig-and-doug-bates.
} 
deplorable surroundings of the modern hospital and helped inspired many

Oregonians to better support patients at the hospital. ${ }^{209}$

This story serves to illustrate the differences in care that the patients at the

Asylum received, even in death. Though the Diamond Square was only a few

hundred feet from the State cemetery physically, the differences in care were vast.

Thurston and Lee were reburied on several occasions and continue to serve as

historical beacons in the community. Only recently have the remains of those who

lived at the asylum been given their proper due. The same can not be said about the

remains of the Indigenous children who were educated at the Willamette Mission.

The remains at Mission Bottom are likely lost forever and the remains which were

buried at the Jason Lee Cemetery lay unmarked. Cemeteries function as markers of

identity; in Salem, that identity in the twentieth century is wholly shaped by the

colonizing efforts of prominent men like Lee and Thurston. Indigenous bodies, in

both life and death, were in the way of "civilizing" the Oregon Country. The absence

of recognition for the remains of Indigenous people who were present during the

early colonization of Oregon shows that people around the turn of the nineteenth

century were unsure of how, or uninterested in, honoring those remains.

\footnotetext{
209 The series of editorials includes the following articles, all written by the Oregonian's editors: "Oregon's Forgotten Hospital," Oregonian, January 9, 2005; "One Flew Out of the Cuckoo's Nest,” Oregonian, January 30, 2005; “A Mad and Mindless Health Policy,” Oregonian, February 13, 2005; "All Dressed Up and Nowhere to Go," Oregonian, March 13, 2005; "Long Hallways, Hard Steps," Oregonian, March 20, 2005; “Oregon's Enlightened Neighbor," Oregonian, April 24, 2005; "Where Sanity Doesn't Prevail," Oregonian, April 30, 2005; “A Delusional State," Oregonian, May 8, 2005; "What About Bob?," Oregonian, May 15, 2005; “Hospital Time," Oregonian, May 20, 2005; “Elda's Ashes,” Oregonian, May 31, 2005; "Fifteen Days to Find Sanity," Oregonian, June 13, 2005; "A Word from Nurse Ratched," Oregonian, June 26, 2005; “A New State of Mind," Oregonian, July 29, 2005; "There's No Turning Back Now," Oregonian, September 18, 2005. These articles can be accessed via the Oregonian's website, available at this link, accessed September 28, 2018: http://s.oregonlive.com/iVi4I6U.
} 
Salem, as the capital and the site of the Methodist Mission, is a place where politics, death, and colonialism collided to create a unique landscape of cemeteries and memory. Portland is another important city in the story of colonization of the west coast. However, Portland has a much different story than Salem when it comes to cemetery development. Instead of early, highly organized efforts to provide communal burial space, there were many partially successful efforts all over the city and over the span of thirty years. Portland did not need to prove itself as Salem did because its prominent location at the confluence of the Willamette and Columbia Rivers proved to be more lucrative for the city than Salem's position on the inland Willamette River. Portland's population boomed almost immediately, creating a much different and more pressing need for cemetery space than what faced Salem during its early years of development. The story of Portland's cemeteries shows what happened when the intersections of colonization and death are further complicated by rapid urbanization. 
Chapter Four: "Procuring a Place More Appropriate," Urban Cemeteries in Portland, Oregon

In front of 3356 Southeast Main Street in Portland, Oregon, there is a single gravestone stuck in the median between the sidewalk and the street. The Oregon Burial Site Guide gives us the above address and the inscribed name: Friedman, Marks. ${ }^{210}$ Much of the inscription is readable, though it is broken in places. Who was Mr. Friedman and why is his gravestone in the parking median? The Oregonian referenced an M. Friedman who lived in Portland during the 1870s and worked at a bakery that offered kosher matzoth for Passover. ${ }^{211}$ Findagrave.com, a publiclysourced repository for cemetery records and photos, reveals something even more surprising: an entry for a "Marks Friedman” who also died on Jan. 1, 1879, aged 65 years old, who was buried in the Ahavai Sholom Cemetery. As this cemetery is reserved for Jewish Portlanders, matzoth and Passover are part of Jewish religious practice, and there are no notices in the newspaper for M. Friedman's matzoth after 1879 , it is very likely that Oregonian-Marks is the same man found in the Ahavai Sholom Cemetery. The likelihood that there would be two Marks Friedmans who died on the same day at the same age in Portland is low. So, that solves the "who" of our question, but leaves the "why" in worse shape. Why are there two markers for this man? Why is one in the parking median for a house just blocks away from busy Hawthorne Avenue? The authors of the Oregon Burial Site Guide were not sure if this

\footnotetext{
210 Dean H. Byrd, compiler, Stanley R. Clarke and Janice M. Healy, co-compilers, Oregon Burial Site Guide (Portland: Binford and Mort, 2001), 711.

211 Morning Oregonian, January 30, 1872, pg. 1; Morning Oregonian, March 19, 1878, pg. 4.
} 
stone marked an enveloped farm burial or was simply placed there as a stepping stone. Johan Mathiesen calls it the smallest cemetery in the county. Even Ahavai Sholom record holders are not sure if Friedman is buried in the cemetery or not. ${ }^{212}$ The City of Portland outlawed burial within city limits in 1873; however, when the city annexed this part of town between 1891-1900, Marks Friedman had (apparently) already been buried in his family's yard for many years. ${ }^{213}$ As best we can guess, Friedman was either disinterred and reburied in the Ahavai Sholom Cemetery or his family left him where he was and built a memorial for him in the cemetery. ${ }^{214}$ Friedman is an example of what happened when a city had inadequate burial services.

Death, burial, and the evolution of cemeteries offer informative and underutilized lenses for the history of urban development, and in the case of Portland somewhat unexpectedly - the history of public versus private supply of services. ${ }^{215}$ The history of the development of burial places in Portland, one of the earliest large

\footnotetext{
${ }^{212}$ Ahavai Sholom (one of the eight congregations that would eventually become Neveh Shalom) was founded in Portland in 1869, ten years before Marks Friedman died. See Elaine S. Friedman, "Congregation Neveh Shalom," The Oregon Encyclopedia Online by the Oregon Historical Society, 2017, accessed March 12, 2018, https://oregonencyclopedia.org/articles/congregation neveh shalom/\#.WhtnSUqnFPa. 213 "1273 - An ordinance to amend ordinance no. 934 entitled 'An ordinance to prohibit interments within the city limits,'” City of Portland Archives, January 15, 1873, AF/38654; "Annexations by Decade" (map), City of Portland, Bureau of Planning and Sustainability, February 7, 2018, accessed September 28, 2018, https://www.portlandoregon.gov/bps/article/51673.

214 Phone interview with Avahai Sholom Cemetery Staff, February 2018.

${ }^{215}$ For information about other public services in Portland, see the following histories of the city: E. Kimbark MacColl, The Shaping of a City: Business and Politics in Portland, Oregon 1885-1915 (Portland: The Georgian Press Company, 1976); Carl Abbott, Portland: Planning, Politics, and Growth in a Twentieth Century City (Lincoln: University of Nebraska Press, 1983); Carl Abbott, Portland in Three Centuries: The Place and the People (Corvallis, University of Oregon Press, 2011); Carl Abbott, How Cities Won the West: Four Centuries of Urban Change in Western North America (Albuquerque, University of New Mexico Press, 2008).
} 
cities in the Pacific Northwest, demonstrates the tension between the public and private supply of services in colonizing American cities trying to meet the needs of their rapidly rising populations and the importance of meeting these needs in order to ensure continued population growth and investment. Only when a group of benevolent capitalists created Riverview Cemetery in the image of other wellknown, rural-style cemeteries like Green-wood Cemetery in New York, did Portland truly have everything it needed to be a fully "civilized" and developed city. Marks

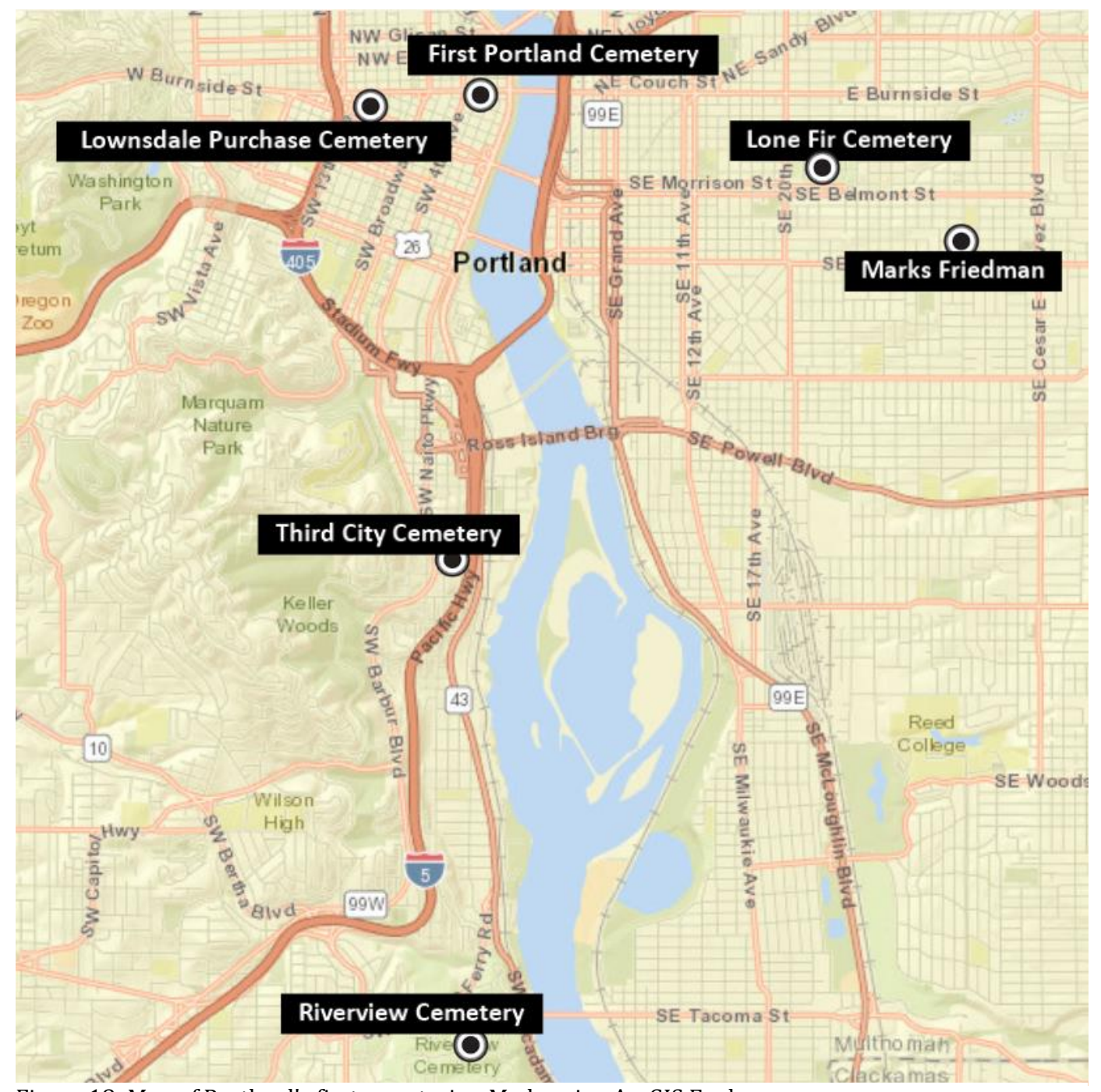

Figure 18: Map of Portland's first cemeteries. Made using ArcGIS Explorer. 
Friedman, and the many other unrecorded burials across the city, are examples of what happens to those who slip through the cracks.

In July 1851, the residents of Portland gathered at the Methodist Church to discuss the "location of the present graveyard and... procuring a place more appropriate."216 At the time, there was no designated burial ground. As complaints grew, citizens looked to one of the only organized groups, a newly formed city government, to solve these problems. A burying ground is a necessity for any place that has residents who value burial, but is city government the best organization to provide for this need? If not, then who has the power or obligation to do so? These are some of the questions that Portlanders grappled with during the earliest years of their city's history.

This story begins with Benjamin Stark, the person for whom Portland's Stark Street is currently named (the street will be changing to Harvey Milk Street soon). Stark purchased land which would eventually grow to be Portland from Asa Lovejoy in 1845. Stark spent much of his time away from his financial investment, sailing back and forth to Oahu in the salt market trade. He returned to his claim in Portland permanently in 1850, after a failed stint in San Francisco during the California Gold Rush. ${ }^{217}$ This absence, though only about five years, left his land untended and since

216 "Cemetery Meeting," The Weekly Oregonian, August 16, 1851, p. 2.

217 G. Thomas Edwards, "Benjamin Stark, the U.S. Senate, and 1862 Membership Issues, Pt. I," Oregon Historical Quarterly 72, no.4 (December 1971): 317-19; Carl Abbott, Portland in Three Centuries: The Place, the People (Corvallis: Oregon State University Press, 2011), 19-20. 
a place for the dead is a necessity for any growing city, his land, by "common consent," became the de facto burying ground of old Portland. ${ }^{218}$

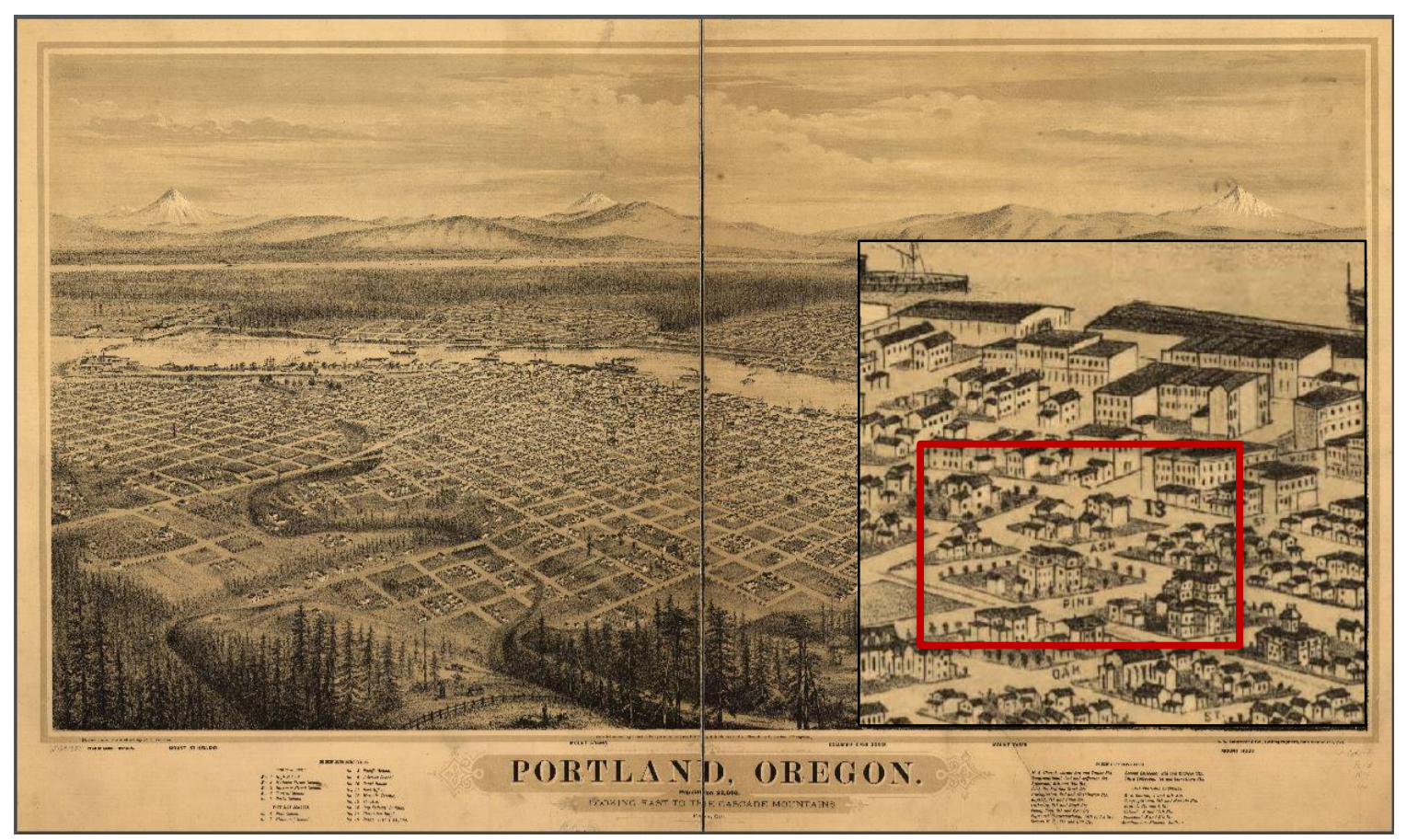

Figure 19: The detail of this 1879 bird's eye map shows the general location of Portland's first city cemetery after it was developed.

According to newspaper accounts, this first burial ground was located between what was at the time of the 1887 article, Second, Third, Pine, and "A" (now Ankeny) streets. It was unofficial and unplatted, meaning there were no laid-out plots, no organization, and no paper documentation of the dead. The graveyard would have been about four or five blocks, or a thousand feet, north of the city, which at that time was generally bounded by Stark, Forth, Taylor, and the Willamette River. ${ }^{219}$ This cemetery was "wild" in the sense that "nature was left

\footnotetext{
${ }^{218}$ Note that this early cemetery on Stark's land is called "City Cemetery \#1" in Byrd, Oregon Burial Site Guide, 704-705. See also “Early Cemeteries," Morning Oregonian, April 26, 1887 p. 2. 219 "Early Cemeteries," Morning Oregonian, April 26, 1887 p. 2; for map see
} 
undisturbed, in a measure, and no systematic effort was ever made to improve the tract, or to beautify it as a permanent resting place."220 The author of the newspaper article described the location in vivid detail, including the fact that "heavy forests covered the site in every direction." The dead were buried "amid the leafy groves" and "beneath the spreading branches of the perennially green" trees. Some relatives built enclosures around the gravesites of their loved ones but otherwise left the land to the wild. However, since the ground had never been officially platted as a cemetery, the graves were dug "here and there" — eventually leading to problems that the city would be forced to address many decades later. ${ }^{221}$

Stark, wanting to develop the land now acting as the communal burying ground, served on a city committee in August of 1851 to comment on the cemetery problem and help find "a place more appropriate." 222 As Portland was officially incorporated on February 8, 1851, Stark thought the city government was the appropriate body to facilitate the need for burial space. ${ }^{223}$ However, the committee appears to have done little to address the problem and, in December of 1851, Stark started running a notice in the Oregonian condemning anyone who would open a grave on his land. He continues: "It is disreputable to humanity, for the public

\footnotetext{
"Portland, Oregon : Looking east to the Cascade Mountains," published by E.S. Grover in 1879, Portland City Archives, A2004-002, M/3954, accessed September 30, 2018, https://efiles.portlandoregon.gov/Record/7243253/. 220 "Early Cemeteries," Morning Oregonian, April 26, 1887 p. 2.

221 "Early Cemeteries," Morning Oregonian, April 26, 1887 p. 2.

222 “Cemetery Meeting," The Weekly Oregonian, August 16, 1851, p. 2.

223 "Portland Historical Timeline: 1843 to 1901," City of Portland Archives, Office of the City Auditor, accessed March 3, 2018, https://www.portlandoregon.gov/archives/article/284518.
} 
authority to leave unsupplied so important a want as a public cemetery... and for the residents of the town to go on from month to month burying their dead in the public highways and upon private property."224 These notices continue for at least six months, though the city would not act on the problem until several years later, in 1853.Stark, a capitalist if there ever was one, called on public authority instead of private interest to meet the needs of deceased Portlanders. This suggests that burial space was still thought of as a public service as opposed to an investment opportunity. Regardless, the city did not, nor does any other authority or group, answer Stark's call and burials continued on Stark's land claim until 1854.

Stark was not the only citizen urging the city to provide a burial ground, as evidenced by a vehement plea for a public burying ground published in an 1852 Oregonian article. After a florid report about the universal nature of death, the anonymous author relates that burial after death "seems to soften the horror of the tomb, and beguiles the mind, secure in its existence, to calmly 'await the inevitable hour."' The author then states plainly: "We must have a cemetery. Who will take the lead? The community is ready and willing to follow." 225 In an April 1853 report to the City Council, Mayor Josiah Failing reported that "the efforts that have been made for the past two years to procure a suitable plat for a cemetery and burial ground [have] been unsuccessful ... I cannot too strongly urge upon you the importance of procuring the desired plat and making such improvements upon it as will fit it for an

224 "Notice is hereby given....," Weekly Oregonian, December 2, 1851, p. 4.

225 “Public Cemetery," Oregonian, October 16, 1852. 
abode for the dead." ${ }^{26}$ At this point, Portlanders were desperate for burial space and city government seemed to be the best organization to meet this need.

By 1854 , the need for burial space had finally reached its boiling point; in fact, the city purchased two separate locations for a cemetery. Regardless, their first attempt at establishing a cemetery was unsuccessful. A cemetery committee appointed by the council reported on April 21, 1854, that the block of land recently purchased from Dan. H. Lownsdale by "Failing, Ladd, and Northup as trustees should be enclosed by a good and substantial fence, and that two and one half acres of land adjoining be purchased of John H. Couch... for a cemetery."227 The council agreed with the committee and on April 25, they passed Ordinance 8 to purchase just that, "not exceeding 200 dollars." 228 This land, block 255, was purchased for the "purpose of providing, laying out, establishing, and otherwise finishing a suitable burial place," and was located between 11th, 12th, Stark, and Washington Streets, about a half mile directly west of the original community burial ground. ${ }^{229}$ For some reason, there were apparently only ever a few burials here. The authors of the Oregon Burial Site Guide posit that Lownsdale's wife, Nancy Gillihan Lownsdale, who

\footnotetext{
${ }^{226}$ Josiah Failing, "Gentlemen of the City Council," April 15th, 1853, p. 3, City of Portland Archives, A2001-049, 2001-09, Council Documents, Finance - General, 1853.

227 Cemetery Committee, "Report relative to a cemetery for the City of Portland," Administration Cemetery Ordinance, 1854, City of Portland Archive, A2001-049, 2001-09, Council Documents. 228 " 8 - An ordinance authorizing the purchase of a parcel of land for a cemetery and enclosing the cemetery and clearing a part of the same," April 25, 1854, City of Portland Archive, AF/36134, accessed February 2, 2018, http://efiles.portlandoregon.gov/Record/77917/.

229 The Oregon Burial Site Guide refers to this cemetery as "City Cemetery \#2," p. 704-705. See "1854 Deed," filed with Multnomah County, surveyed September 10th, 1853. Copy accessed via Oregon Commission on Historic Cemeteries Database, record number 2158_2, Oregon State Parks and Recreation, Heritage Division Records.
} 
died on April 5th, 1854, was buried here; however, no modern records are known to verify this. Adding to the mystery, later the same year, the city council passed Ordinance 23, which authorized the city to purchase more cemetery land on the southern end of the city from James Terwilliger and Finice Caruthers. ${ }^{230}$ Why did the city purchase another parcel of land?

It is unclear why Portland officials never developed block 255 but a lawsuit brought against the city several years later may shed some light on the situation. The case stated that Lownsdale, after selling land to the city in 1854 , sold the same blocks he had previously sold to the city, (blocks 132, 172, 211, 218, and 255) to Lansing Stout for $\$ 3,800$ on April 1st, 1858. All lots were supposed to be public property and lot 255 was specifically reserved as a cemetery. On the same day, Stout sold a portion of this land to Alonzo Leland, who subsequently built a house there. When the city tried to reclaim the property, Leland and Stout filed a suit. An Oregonian reporter lambasted the trio: “does any man of common sense... believe that Lounsdale [sic] owned or had the right to sell these public squares; or that Stout and Leland have the least shadow of a just lawful or equitable title to them?... Our corporate authorities have said no! Our judicial tribunals have said no! Public sentiment says no! And the strong arm of truth, justice, and right, will... pronounce Lounsdale, Stout and Leland, and all their associates a band of lawless trespassers,

230 " 23 - An ordinance authorizing the procuring of a parcel of land for a cemetery and improving the same," September 18, 1854, AF/31469, 11/ED/48684, City of Portland Archive, accessed March 11, 2018, http://efiles.portlandoregon.gov/Record/77902/. 
unworthy of the confidence or support of the community in which they now

reside."231 The case eventually went to the Oregon Supreme Court where the court ruled in favor of the City of Portland. Whether the land belonged to the city or not, city officials never established a cemetery on block 255 and the reasons why are likely linked to the proceedings in this case.

While the reasons for the acquisition and eventual abandonment of the city's second attempted cemetery remain largely a mystery, the development of the third cemetery is well documented; at this point, Portlanders still expected that the city would be able to provide burial space. ${ }^{232}$ On September 21, 1854, the City Council passed Ordinance 23, "authorizing the grooming of a parcel of land for a cemetery." James Terwilliger and Finice Caruthers had both agreed to donate five acres each of their adjoining land south of Portland for the purpose. The council allocated four hundred dollars towards its development and each lot in the cemetery would be sold for twenty-five dollars. ${ }^{233}$ This cemetery was located about a mile and half south of downtown Portland, along Macadam Road, between Abernathy and

\footnotetext{
231 "Disinterested and Abiding Interest in Oregon - How They Obtain It," Weekly Oregonian, June 27th, 1850; "Our City Government," Weekly Oregonian, December 29, 1860, p. 1; "City of Portland Jumping, or More Properly Speaking, Attempting to Steal the Public Property of Those Who Have Made Portland What It Is," Weekly Oregonian, August 20, 1859. See also Leland v. City of Portland, 2 Oregon 46. For more insight in this case, see Jos. G. Wilson, Reports of Cases Decided in the Supreme Court of the State of Oregon from 1862 to 186, Vol. 2 (San Francisco: Bancroft-Whitney, 1906), 46-49, accessed March 11, 2018 via Google Books, https://books.google.com/books?id=HegKAQAAMAAJ\&lpg=PA46\&dq=\%22Leland $\% 20 \mathrm{v} . \% 20$ City $\% 2$ 0of\%20Portland $\% 22 \% 2 \mathrm{C} \% 202 \% 200 \mathrm{r} . \% 2046 \& \mathrm{pg}=\mathrm{PA} 49 \# \mathrm{v}=$ onepage \&q=\%22Leland $\% 20 \mathrm{v} . \% 20 \mathrm{City}$ \%20of\%20Portland\%22,\%202\%200r.\%2046\&f=false.

232 This cemetery is referenced in Byrd, Oregon Burial Site Guide, 705 as "City Cemetery \#3." 233 " 23 - An ordinance authorizing the procuring of a parcel of land for a cemetery and improving the same," September 18, 1854, AF/36149, City of Portland Archive, accessed February 11, 2018, http://efiles.portlandoregon.gov/Record/77902/.
} 
Bancroft Avenues. ${ }^{234}$ Today, Interstate 5 cuts directly through the site. With the development of this cemetery, Portlanders finally had a cleared and legitimate place to house their dead. Unfortunately, even though the city was attempting to provide

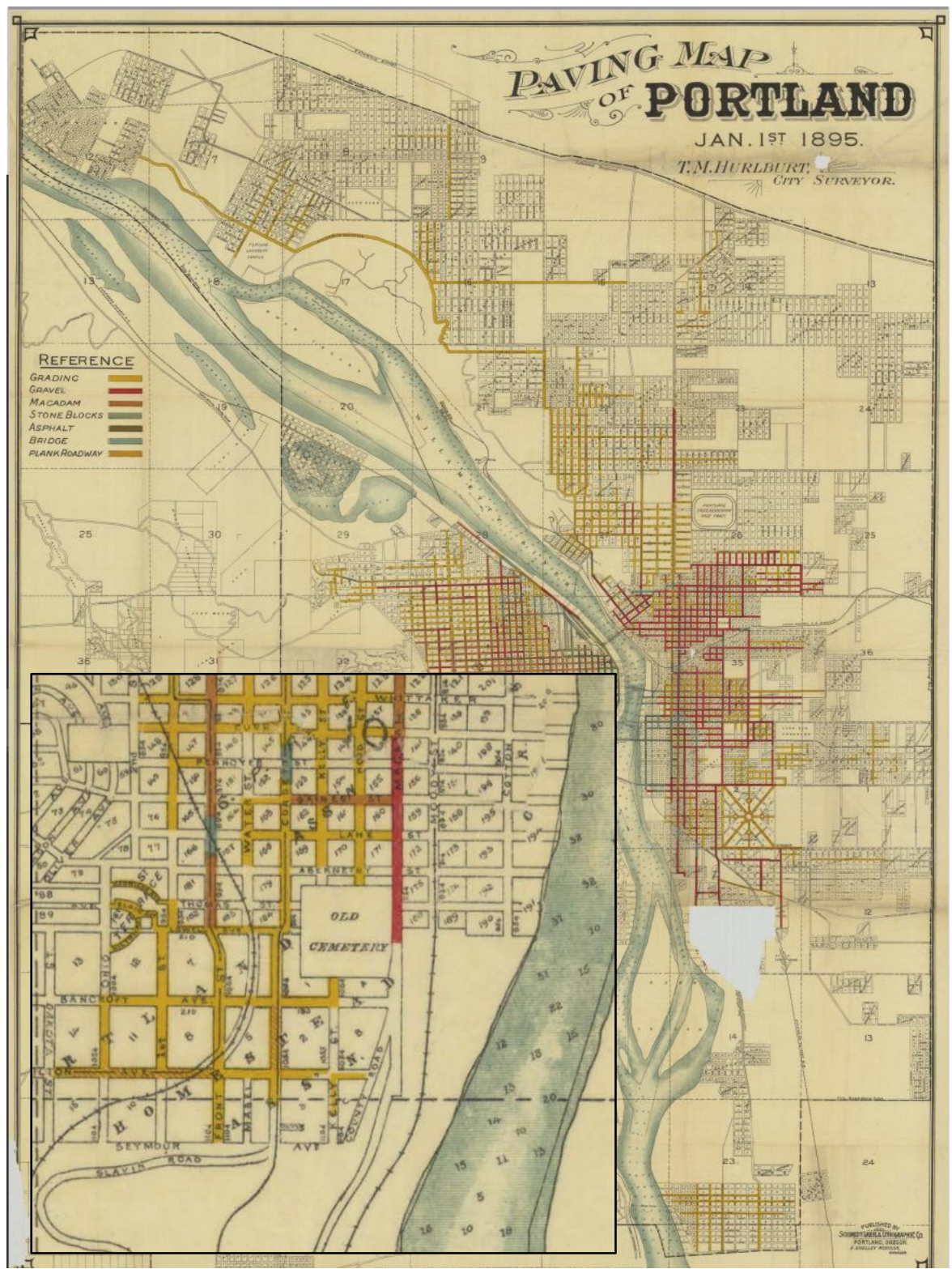

Figure 20: The detail from this 1895 paving map shows where the old cemetery was located. Courtesy City of Portland Archive.

234 "Paving Map of Portland," surveyed by T. M. Hurlburt, January 1, 1895, City of Portland Archive, accessed March 11, 2018, http://efiles.portlandoregon.gov/webdrawer.dll/webdrawer/rec/16938/view/. 
this public service, the new cemetery would become dilapidated and unused within just a few decades.

The committee in charge of the development of the cemetery took their jobs seriously and initially, it looked like the city, and not private enterprise, would successfully provide this necessary service. In a report dated January 20th, 1855, the committee described the steps taken to prepare the cemetery in a letter to the common council. It cost one hundred dollars to have 0. A. Grooms plank and install a bridge. Other expenses included a Mr. Gill Tucker who required one-hundred and sixty dollars to clear the east half of the land and installing the fence, for which Grooms - being the "lowest responsible bidder" - charged a steep $\$ 450$ dollars. During these improvements, the committee expressed concern about delays which occurred because "there [was] no money on hand to commence with" and those who were interested in purchasing lots wanted to see demonstrated progress before they would buy. This progress was unattainable without the necessary funds. Regardless, at the first public auction they sold eight lots for a total of two hundred dollars. ${ }^{235}$ The problem with insufficient funding foreshadowed the problems city officials (as opposed to private investors) had with fulfilling the need for burial space. Because funds were limited by low tax income, to provide burial space at all, the city had to use donated land. Somewhat predictably, Portlanders soon discovered that the land was ill-suited for the job.

235 "Report of Committee to procure a parcel of land for a city cemetery, report," January 20th, 1855, A2001-059, 2012-30, Cemetary 1854-1887, City of Portland Archive. 
As officials were working to clear the new cemetery south of town, there was still the issue of the old cemetery on Stark's land - many bodies remained and Stark wanted to develop. As part of the ordinances passed in 1854, it was recommended (possibly by the mayor, though the preserved documentation is unclear) that "in order to facilitate the removal of the buried dead from that part of the city which has been occupied as a public cemetery," citizens could buy a half lot at a lower price for their disinterred relatives. ${ }^{236}$ Since Stark's 1851 notice, burials at the Stark Street location had slowed, and many families removed their departed relatives to other locations. This left the old cemetery in a rather spooky state, as one Oregonian reporter recounted in several "serio-ludicrous personal incidents:"

Stray paths (at that time the streets were roughly surveyed, but had never been opened) led in different directions across the grounds, and, while wandering through the gloomy woods after dark, it was no infrequent occurrence for persons to stumble into these sepulchral openings, to their great disgust and discomfiture. Small boys, and even large lads, often pitched headlong into the enclosed holes while rambling about after night... and were scared out of several years' growth by the terror of the accident, which the superstitious associations of the place so greatly magnified. ${ }^{237}$

Finally, in 1857, city officials began removing the remaining bodies from the old ground. According to the report by the committee charged with caring for these remains, there were 38 bodies to disinter. A man named William James contracted with the city to remove the bodies to the new cemetery south of town for eight

\footnotetext{
236 Unnamed document, A2001-049, 2001-09, Council Document, Administration - Cemetery Ordinance, 1854, City of Portland Archive.

237 "Early Cemeteries," Morning Oregonian, April 26, 1887, p. 2.
} 
dollars each. ${ }^{238}$ The disorganized nature of the early Stark cemetery ensured that disinterring these remains would not be as simple as city officials hoped and problems arose at this location every few decades.

Though the city eventually provided burying space for its citizens, during the crucial few years between Stark's notice in 1851 and the development of the city cemetery south of Portland in 1855 , people still needed a place to bury their deceased loved ones and a privately owned cemetery entered to meet that need. Mount Crawford Cemetery (later Lone Fir), located on the east side of the river at what is now SE 26th and Stark Streets, was platted in 1855 and was the first privately owned (and legitimate) cemetery in Portland. James B. Stephens had purchased the land that would become East Portland (DLC \#53) from the Hudson's Bay Company in 1850. Stephens buried his father, Emmor Stephens, on a piece of this land which overlooked the Willamette River in 1846. James B. Stephens and the man who owned the adjoining claim (DLC \#54), Seldon Murray, each sold a section of their property to Colburn Barrell in the early 1850s. As part of the sale, Barrell agreed to tend Emmor Stephens' grave. In 1854, Barrell's business partner, Crawford Dobbins, was killed in the infamous explosion of the Gazelle Steamer. ${ }^{239}$ His body was buried in the Stark Street cemetery until 1855, when Barrell exhumed Dobbins and buried him near Stephens' grave. During this process, Barrell decided

\footnotetext{
238 "Report from Com Streets \& etc., Removal of Bodies from Grave Yard," November 24, 1859, A2001-049, 2001-09, Council Documents, Police - Body Removal, 1857, City of Portland Archive. ${ }^{239}$ Crawford Dobkins died several weeks later from injuries sustained during the accident. See “Terrible Accident!!!," Weekly Oregonian, April 15, 1854, p. 2 and “Early Cemeteries," Morning Oregonian, April 26, 1887 p. 2.
} 
to plat the area as a cemetery, since Portland citizens were in desperate need. ${ }^{240}$ Many of those buried in Stark's land claim cemetery were moved here instead of the city cemetery south of town, and quickly, the cemetery became the most popular burial place in Portland, largely because of the almost immediate failure of the cityrun burying ground.

As it turned out, the previously noted committee report on the monetary struggles facing the third City Cemetery were merely the tip of the iceberg, indicating the limitations of city power in early Portland. After the city cemetery committee had done their best to prepare the location for interments in 1855 , there were several dozen burials over the next six or seven years. However, the land itself made the development of a cemetery here as hard as possible. Not only was it "clothed with a dense forest," which was costly to clear, the "steep character of the ground, and the... numerous springs" created a less than ideal burial ground. In fact, "so full was the earth of these veins of water that a grave dug and left open for a few hours would become half filled from the copious seepage."241 The land was vastly under-equipped to serve the purpose for which the city intended it and problems with the site started to snowball as time passed.

As early as 1863, just nine years after Finice and Terwilliger donated the land, citizens were complaining about the state of City Cemetery \#3 in the

\footnotetext{
240 Mary Glenn, "Lone Fir Cemetery," National Register of Historic Places Registration Form, Friends of Lone Fir Cemetery, Portland, Oregon, July 6, 2007, sec. 8, p. 1, 3. 241 “Early Cemeteries," Morning Oregonian, April 26, 1887 p. 2.
} 
Oregonian, showing that the city was far behind other cities in area in providing appropriate burial space. Because of the spongy land, it had "not been used for many [?] years." 242 The City Council, under mounting pressure from Portland citizens, required the Committee on Streets and Public Property to "examine into the condition of the city cemetery, and report at the next meeting."243 The land could be drained "by the expenditure of a few hundred dollars," reported an opinion piece in the Oregonian, allowing the land to better serve its designated purpose. The author urged the city to do so as there were several reasons that a cemetery south of Portland would be more convenient to its citizens than Mount Crawford, which was located across the river and only accessible by ferry. Funerals had to wait for "half an hour or more" on rainy days to board the ferry and cross. The city cemetery south of town also had many hundreds of plots left, meaning that it would be able to meet the needs of Portland's citizens for a number of years. ${ }^{244}$ Concerns about the longevity of Mount Crawford were already mounting because of Portland's rapidly increasing population and the relatively small size of the space. The city needed another burial ground and many thought city officials could provide for that need with the land they already had, just as earlier promised.

In the meantime, the privately-owned Mount Crawford was becoming a very successful cemetery, much to Colburn Barrell's eventual chagrin and proving that cemeteries were not yet a profitable investment, even when the demand for burial

\footnotetext{
242 "City Cemetery," Morning Oregonian, September 29, 1863.

243 "City Council," Morning Oregonian, July 31, 1863.

244 “City Cemetery," Morning Oregonian, September 29, 1863.
} 
space was high. He offered to sell the land to the city — an offer he thought they would accept due to the condition of City Cemetery \#3. However, city officials rejected Colburn's offer on multiple occasions. At the November 1st, 1861 City Council meeting, Barrell first introduced his request to the council. Though the council appointed a committee to consider the offer, they pushed out the decision even though Barrell sent in another petition. ${ }^{245}$ The council took no action on the offer and, after a few years, Barrell turned to other Portlanders to take the land off his hands. In an advertisement dated June 7, 1865, Barrell officially offered the "beautifully located," and "entirely cleared" cemetery for sale. ${ }^{246}$ Apparently, he was unable to entice anyone as he offered the cemetery to the city again in mid-1865. The committee issued yet another report rejecting Barrell's offer, stating "we can not recommend the purchase of cemetery ground on either side of the river, but we would rather suggest, that this question be left to be developed by the enterprise of private parties, and that the city be no longer regarded as in the market to purchase grounds for the above purposes."247 However, in July, the council was edging toward a decision in Barrell's favor. The Committee on Health and Police reported to the council that Mount Crawford, though high in price, was likely the best deal the city could hope for if the council intended to secure a public burying ground and "taking

\footnotetext{
245 See Colburn Barrell, "To the Hon. Council of Portland city Oregon," November 1st, 1861, Administration - 1861, A2001-049, 2001-09 Council Documents, 8/8, City of Portland Archive and Colburn Barrell, "Petition of Colburn Barrell in relation to Cemetery," May 7th, 1862, Administration (General) 1862, A2001-049, 2001-09, Council Documents, 8/32, City of Portland Archive. 246 “Mount Crawford Cemetery!," Morning Oregonian, June 7, 1865. 247 "Report of Com. of H. \& C.," 1865, Administration - Cemetery, 1865, A2001-049, 2001-09 Council Documents, 11/35, City of Portland Archive.
} 
into account all the circumstances." 248 On September 22, 1865, the city council, finally swayed by Barrell's offer, attempted to complete the transaction. But thwarted again, the mayor, Henry Failing, officially vetoed the ordinance. He objected to the "extraordinary expenditure so largely in excess of the revenue of the year."249 The city could not afford another cemetery and Mount Crawford, run and funded by Barrell, was already a great price - free. The changing opinions of the city council further illustrate some of the problems government faces when trying to address the needs of their citizenry: if a private interest was already meeting the need (even unhappily), why should the city government intervene?

Portlanders were similarly divided on the question of purchasing Mount Crawford, though the argument was not about public or private management but where the cemetery was located. One citizen who disagreed with purchasing the land asked, "why a private cemetery should [illegible] on the east side of the river, at such inconvenience and expense, when there [were] any number of suitable sites accessible to [illegible] on this side of the river?" Further, the land that was donated by Terwilliger and Caruthers "has never been used" and should be drained. The river was dangerous to cross at times of high weather and "at all times the trip [to Mount Crawford was] excessive for funerals." Purchasing the distant cemetery would be a mistake, if only because the city should focus on finding a more

\footnotetext{
248 Health and Police Committee report, "Report of Com on Health \& Police on cemetery," July 21st, 1865, Administration - Cemetery, 1865, A2001-049, 2001-09, Council Documents, 12/25, City of Portland Archive. 249 Henry Failing, Mayor, “Veto of Mayor," September 22, 1865, Administration - Cemetery, 1865, A2001-049, 2001-09 Council Documents, 11/35, City of Portland Archive.
} 
accessible site on the west side of the river. ${ }^{250}$ In response, a person who identified themselves as "thirteen years a resident of Portland," wanted the ordinance to pass since the ease of crossing the river the city should increase as the "city and county improve" and Portland simply needed better, well-cared-for burial space. ${ }^{251}$ The land south of the city was not working and Mount Crawford cemetery could fulfill that need. Both citizens lamented the city's failure in providing the town with a suitable cemetery.

Determined to rid himself of the cemetery land, Barrell tried one last time to sell the cemetery in 1866 - though by this point, city officials were no longer interested in providing this service, officially leaving the way open for private interest. On April 4th, the council present a report written by an obviously exasperated Barrell. He related that in 1855, "at the earnest request of many citizens and in conformity with [his] own feelings and judgment as regards the necesity of a publick cemetery for the city of Portland," he had purchased, cleared, and enclosed "with fence ten acres of land for that purpose." The site was beautiful, had appropriate soil, and was "universaly used by the community." He describes the costs of clearing the land that he had made back "a sum not at all equivilant to the services rendered during the last ten years." This well-plotted and oft used cemetery, available for a mere $\$ 4,000$, was just what the city needed, but Barrell's

250 "About a City Cemetery," Morning Oregonian, June 20, 1864, p. 3. 251 “A Public Cemetery," Morning Oregonian, June 23, 1864. 
offer came about twelve years too late. ${ }^{252}$ The eventually voted the ordinance down, 2-6.253 The city council was officially out of the cemetery market, but that does not mean the old cemetery was done with the city council.

Thankfully for Barrell, a group of private businessmen saw Mount Crawford as a possible investment, concurrent to other cemetery-based business ventures on the East Coast, and purchased it on September 20,1866 for the price of $\$ 5,100.254$

On August 10, 1866, (the county recorder did not officially mark the purchase until after the group formed) the Portland Lone Fir Cemetery Company had their first meeting and adopted a series of bylaws to guide their organization. Levi Anderson was the president, B. P. Cardwell was the secretary and treasurer, and Robert Pittock was the superintendent. ${ }^{255}$ A new name came with the new owners and there is a rumor that Barrell's wife, Aurelia, suggested Lone Fir for the singular fir found in the cemetery. ${ }^{256}$ Barrell was finally free of his duty and a privately owned company stepped in to provide long-term, permanent care of the dead where the city had for so long failed to do so.

While Barrell moved on from cemetery care, Portland officials were facing decades of trouble brought on by the city's attempt to provide burial space; the first

\footnotetext{
252 Colburn Barrel, "In [?] Relation to Mt. Crawford Cemetery," April 4th, 1866, Administration Mount Crawford Cemetery, 1866, A2001-049, 2001-09 Council Documents, 14/21, City of Portland Archive.

253 Minutes of the City Council of Portland, Oregon, April 11th, 1866, p. 303, City of Portland Archive. 254 Property legal records, 1866, 1874; Resolutions, 1911, Lone Fir Cemetery, MSS 2010, 1/2, Oregon Historical Society Research Library.

255 “Cemetery Association Records, Vol. 1 - Articles of Incorporation and Minutes, 1866-1928,” p. 6, 9, Lone Fir Cemetery, MSS 2010, 6/1, Oregon Historical Society Research Library.

256 Mary Glenn, "Lone Fir Cemetery," National Register of Historic Places Registration Form, Friends of Lone Fir Cemetery, Portland, Oregon, July 6, 2007, sec. 8, p. 8.
} 
problem was the miserable condition of the third City Cemetery south of town - a possible opportunity for the original donors of the land. On July 11, 1865, Terwilliger petitioned the city council to reconvey the land to him as the city had "for many years neglected to improve the said land for cemetery purposes," had "wholly failed to build and improve the said road," and had "in fact abandoned the said land so far as using the same for cemetery purposes is concerned." 257 The Judiciary Committee referred the question to the city attorney and he addressed several aspects of the question. First, he reported that the city, according to the city charter, "could legally receive a conveyance of ground for cemetery purposes outside the city limits" and that if the conditions of the deed "have been performed by the city, it is indefensible."258 Taking this advice, the committee found that "all the conditions attached to the deed" were "complied with by the city, and the title so far as these parties" (Terwilliger and Caruthers) were concerned was "unquestionable." Further, Terwilliger had informed the committee that he would not seek reconveyance if the City improved the land for the purpose for which it was donated. ${ }^{259}$ This report settled the matter for now though Terwilliger eventually

\footnotetext{
257 Stout and Landers, agents to John C. Terwilliger, "To the Common Council of the City of Portland," July 11th, 1865, Administration - Cemetery, 1865, A2001-049, 2001-09 Council Documents, 12/25, City of Portland Archive. See also, "The City Cemetery Question," Morning Oregonian, July 31, 1865. 258 J. N. Mitchell [?], for W. V. Dolph, City Atty., "To P. C. Schuyler, City Committee on Judiciary," July 27, 1865, Administration - Cemetery, 1865, A2001-049, 2001-09 Council Documents, 12/25, City of Portland Archive.

259 P. C. Schuyler, Jr. and F. A. Clark, "The committee find that all the conditions...," July 28, 1865, Administration - Cemetery, 1865, A2001-049, 2001-09 Council Documents, 12/25, City of Portland Archive.
} 
brought up the matter again, and several more decades would pass before Portland government was free of the cemetery.

As the city further abandoned the third City Cemetery, the Lone Fir Cemetery Company continued to beautify their land, though its status as one of the only official and well-used cemeteries proved a significant problem for the rapidly growing city. Even some of the earlier complaints about long ferry-waits were addressed in 1872 with the completion of the "L" Street Bridge. ${ }^{260}$ This popularity came with a downside: Lone Fir was not large enough to meet the burial needs of Portland for long. Indicative of the distance the city council was putting between itself and care of the southern city cemetery, the council passed an ordinance banning all burials within city limits in $1871 .{ }^{261}$ This action only increased the need for sanctioned, usable burial ground as the city's population was exploding. In 1860, the population in Portland was 2,874; by 1880 , the population increased over $500 \%$ to $17,577 .{ }^{262}$ Nevertheless, city officials ignored the cemetery land south of the city. As pressure for more burial space mounted in the quickly growing city, private enterprise again stepped in to meet this city need, likely just as city officials had hoped it would.

\footnotetext{
260 Though the bridge helped to get reliable access across the river, complaints about getting to the east side of the city continue to the current day. "L Street Bridge," Morning Oregonian, August 7, 1872, p. 3 and "Death's Silent Home," Morning Oregonian, April 25, 1879, p. 3. 261 "Ordinance No. 934: An Ordinance to Prohibit Interments," Morning Oregonian, March 3, 1871, p. 4.

${ }^{262}$ Campbell Gibson and Kay Jung, "Historical Census Statistics On Population Totals By Race, 1790 to 1990, and By Hispanic Origin, 1970 to 1990, For Large Cities And Other Urban Places In The United States," February 2005, Population Division, Working Paper No. 76, United State Census Bureau, accessed March 11, 2018, https://www.census.gov/population/www/documentation/twps0076/twps0076.pdf.
} 
In 1879, almost twenty-five years after Barrell established Mount Crawford, several private investors stepped in to establish a new cemetery for the city, finally providing a service that would soon begin to significantly affect the city if left unaddressed. Recognizing that Lone Fir was lacking in several aspects, as one reporter related: "the flat and barren surface, its situation by which funeral and visiting parties are compelled to cross an unbridged and sometimes roughened river, the tameness and dullness of the view on every side, and above all, that it is near and even now partly surrounded by a rapidly growing city," W. S. Ladd, H. W. Corbett, and Henry Failing took the "matter in hand personally." They purchased 286 acres of land far south of the city at a price of $\$ 10,000$. The land was far better suited than Lone Fir (or any of the city choices, for that matter): it was three miles from the city, easily accessible, had a mountain stream that could be tapped for fountains and artificial lakes, but chief among the boons of this new location was the "grand view which its situation and elevation afford, Mounts Hood and St. Helens may be viewed from their very base, and 'Beautiful Willamette,' with evergreen banks, the numerous islands, her twin cities of Portland and East Portland, with Albina and the deep forests beyond, form a picture grand and beautiful."263 This new cemetery took its name from one of these features: Riverview.

This cemetery, much like the Odd Fellows Rural Cemetery in Salem, was created in the image of cemeteries on the East Coast, an indicator that Portland was as well-developed as any similar city there. An article in the Oregonian celebrated

263 “Death's Silent Home," Morning Oregonian, April 25, 1879, p. 3. 
the creation: "it must now be conceived by the reader that this cemetery will be a place like our new cemeteries East, which will be visited, not merely by those who have friends sleeping beneath the shadows of its majestic trees, but will be a favored resort, where the people may quietly ride or stroll through its shaded avenues, enjoying all that is so beautiful in nature, amid the sweet songs of the birds." ${ }^{264} \mathrm{An}$ eastern-style cemetery was a marker of a colonized town that was ready for more people and more investment, a fact which Ladd, Corbett, and Failing must have recognized.

One of the most striking details about Riverview, opposed to cemetery trends on the East Coast, is that Ladd, Corbett, and Failing founded the cemetery as a nonprofit. 265 The only money they required in return for their investment in the land was what they put into the endeavor. As historian David Charles Sloane relates, at the end of the nineteenth century, the motivations for creating cemetery space had expanded beyond simple need. With the popularity of Mount Auburn and others, aesthetics became an important factor in deciding where to bury a loved one. Additionally, another reason for "establishing new cemeteries was financial gain."266 John Jay Smith, one of the founders of Laurel Hill Cemetery, included information about the profits made from the sale of lots in the cemetery: his "income was large

\footnotetext{
${ }^{264}$ E. O. Schwagerl, "The New Cemetery," Morning Oregonian, January 1, 1880, p. 3.

265 See part two, "Commercialization of the Cemetery, 1855-1917," in David Charles Sloane, The Last Great Necessity: Cemeteries in American History (Baltimore and London: John Hopkins University Press, 1991) for a in depth discussion of this trend. For information about the founding of the cemetery, see "Historical Tour: Explore Portland's Rich History," Riverview Cemetery, no date, https://www.riverviewcemetery.org/about-us/facilities/historical-tour/ (accessed August 8, 2018). ${ }^{266}$ Sloane, The Last Great Necessity, 129.
} 
for those days." 267 He was also a founding subscriber to the Woodlawn Cemetery in the Bronx, opened in 1863, and his three-hundred shares were worth nine times the cost in 1892.268 While speculators still had to be careful of public perception, cemeteries could be an incredibly valuable investment if well-placed and welladvertised. ${ }^{269}$

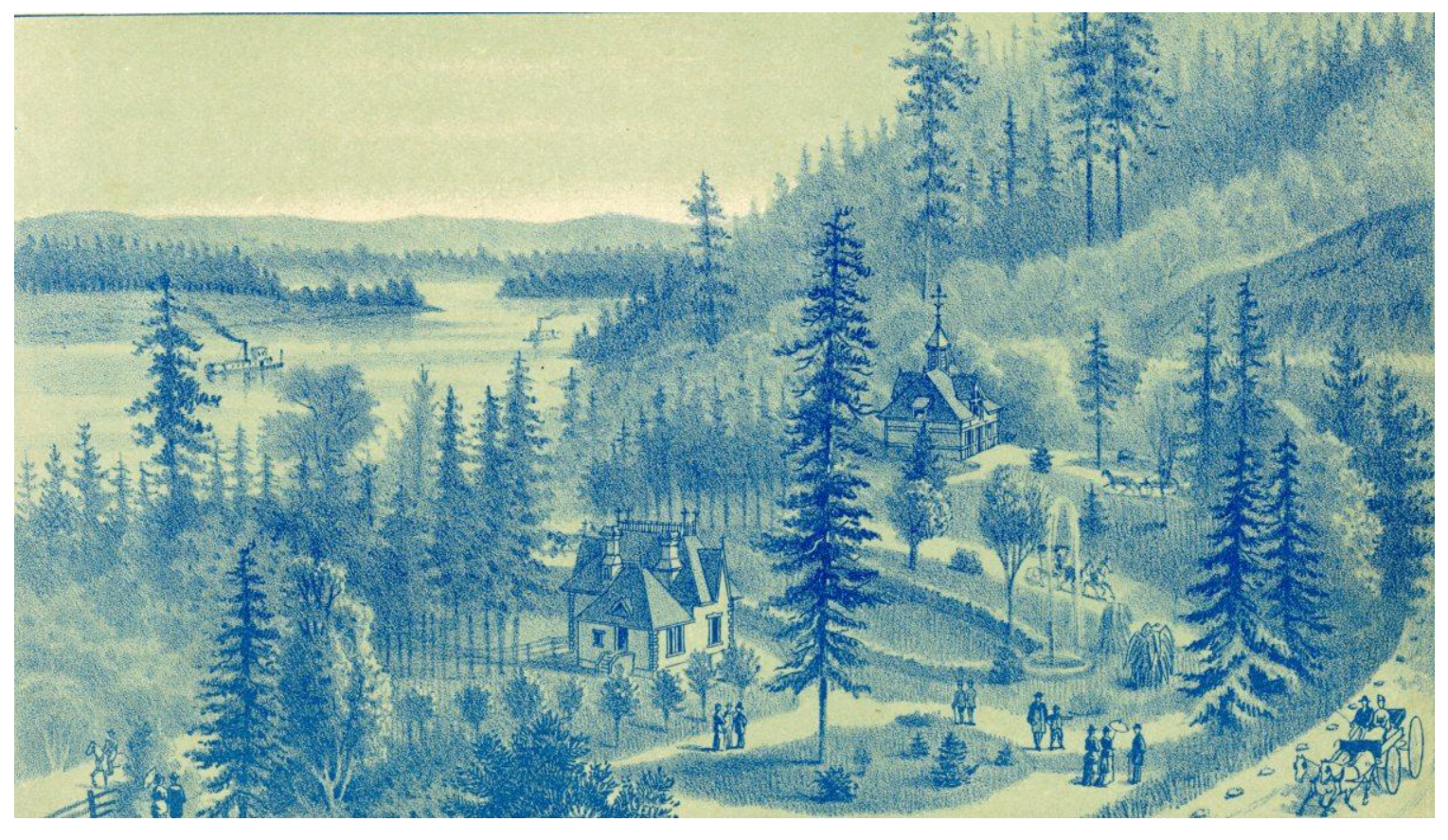

Figure 21: This image from 1887 shows Riverview cemetery in its early years. Photo courtesy City of Portland Archive.

The founders of Riverview, while they were likely motivated by a sincere desire to provide what was a desperate need, also recognized a cemetery as the "last great necessity" that Portland needed to truly establish itself as a modern, colonized city which had the capacity for more investors and a larger population. The

\footnotetext{
${ }^{267}$ John Jay Smith, Recollections (Philadelphia, 1892), 291 as quoted in Sloane, The Last Great Necessity, 129.

268 Sloane, The Last Great Necessity, 129.

${ }^{269}$ For image see, “A2004-002.7505: Riverview Cemetery," January 1, 1887, A2004-002, AP/33767, City of Portland Archive.
} 
cemetery itself was a non-profit, but its creation represented an investment in the city itself - one that proved to be very profitable for Corbett, Ladd, and Failing. The situation described by Elias W. Leavenworth, after leading the fight for a rural style cemetery in 1850s New York, is applicable to the situation in Portland:

An ample, permanent and attractive resting place for our dead, seems to be the last great necessity of our city. Water and gas - railroads and canals - a salubrious climate - a fertile soil - prosperous agriculture, commerce and manufactures, have supplied the great wants of our town - filled our laps with plenty and made our homes the abodes of happiness and peace. But while laboring so diligently and successfully for the wants of the living; we had forgotten what was due to the dying and the dead. No adequate, suitable or permanent provision had been made for their repose. ${ }^{270}$

A reporter for the Oregonian stated it plainly by saying "it has been remarked that people exhibit their state of civilization in their care for the dead, and upon this theory we shall now appear in much better light than formerly."271

The fact that Riverview was a non-profit was part of its appeal and actually contributed to its success. In an Oregonian article published just after the opening of the cemetery, in addition to lauding the location, care, and improvement, the author dedicated several paragraphs to the "entire absence of the element of profit." There are even details about how the cemetery association was set up. Careful accounting tracked all spending, and once the cemetery association was founded, the entire property was "formally transferred to it for a price which exactly reimburses them

\footnotetext{
${ }^{270}$ E. W. Leavenworth, "Dedication of Oakwood Cemetery," The History, Incorporation, Rules and Regulations of Oakwood Cemetery (Syracuse: J. G. K. Truair and Co., 1860) 20. 271 "Through the generous enterprise of a few individuals...," Morning Oregonian, November 7, 1883, p. 2.
} 
for their outlay." Members and trustees were barred from receiving any compensation or any division of profits; all other profits were to go to the "care and improvement of [the] grounds." ${ }^{272}$ Corbett, Ladd, and Failing had made a great deal: an even break in funding for the future of Portland's burial space, and with it, the economic future of the city secured.

While the city's burial problems were finally addressed, the ownership of the city cemetery south of town was fast becoming an entirely different problem for city officials, further showing that the city had been ill-equipped from the beginning to provide this public good. Though most, if not all, burials had been removed from the third City Cemetery, the question of who owned the land was not settled. In 1885, twenty years after his original request, James Terwilliger again petitioned the city to return the land he had originally donated. The petition, which the council referred to the committee on the judiciary, claimed that the city had "not complied with the conditions set forth in the deed."273 Though the exact timeline is unclear, Terwilliger repossessed the land and, just over a year later, in March of 1887, the city sued Terwilliger to reclaim it. ${ }^{274}$ According to a newspaper account relating the suit, the city had, at about the same time, incorporated that land into the city boundaries as well as extended the ordinance on prohibition of burials within the city limits. The council then cut up some of the cemetery land into lots and streets to sell. Terwilliger claimed that since the city was clearly not using the land for the

\footnotetext{
272 "The River View Cemetery," Morning Oregonian, November 7, 1883, p. 3.

273 "The City Council," Morning Oregonian, August 20, 1885, p. 8.

274 "The City Defeated," Morning Oregonian, September 17, 1887, p. 5.
} 
purposes laid out in the original deed, he should get the land back. The land's estimated worth was nearly $\$ 50,000$ dollars, equivalent to more than 1.25 million dollars in 2018. Terwilliger, then an "old and well-known capitalist" stood to make a fortune from city's failure to keep their word. ${ }^{275}$ The court set the suit of Terwilliger versus the City of Portland, described in the paper as "worth fighting for," on the 29th of June, 1887.276 The first trial ended with a hung jury and second trial convened on September 15th, 1887.277 The second jury decided in favor of Terwilliger and the city lost the claim to this valuable piece of land. City officials were now, for better or worse, done with their attempts to provide burials space for Portland's citizens.

As time passed, memory of the city cemeteries (both official and non-official) faded from both the Portland landscape and the consciousness of its citizens. During the Terwilliger trial, just some thirty years since the initial development of the cemetery, witnesses had memories of the cemetery though they recalled few of the individuals who were buried there. C. H. Cooke was an undertaker for twenty years who came to Portland when the "Stark St. Cemetery" was still in use. He remembered when the city established the track and had stopped burying people there when a man named P. Thompsan informed him the property was private. It is unclear who Thompsan was and why he claimed the city property was private. Cooke had buried many there: "Chinese, white, and African, some children."

\footnotetext{
275 "Suit over the old cemetery," Morning Oregonian, March 23, 1887, p. 3.

276 "Worth fighting for," Sunday Oregonian, June 5th, 1887, p. 5.

277 “The Courts: Notes," Morning Oregonian, September 15, 1887, p. 8.
} 
According to another witness, Andy DeLui, the last person buried at the cemetery was a child in 1879. Most of the burials happened on the Caruthers side of the cemetery and there were only "one or 2 Chinese removed" from the Terwilliger section of the cemetery. F. Hachway reported that the Chinese community had removed the Chinese interred there as the railroad had informed them there would be a track laid through the plat.278 In 1887, an article in the Morning Oregonian recalled in great detail the Stark land claim burial ground. ${ }^{279}$ In spite of these memories, all the city cemeteries would fade into obscurity and confusion, resulting in at least one unpleasant surprise for the unexpecting workman on Burnside.

The uncertain boundaries of the Stark land claim cemetery, the first cemetery which was never officially sanctioned, caused problems when officials and investors started to develop and improve the area around 3rd and Burnside. In addition to the skull mentioned in the beginning of the chapter, there were other discoveries of remains in this area. ${ }^{280}$ Just a few decades previous to the road widening, around 1911, workmen found human remains during excavation for the Multnomah Hotel, located on the adjacent southwest corner of 3rd and Ash Streets. ${ }^{281}$ "Oft repeated stories about 'dead men's bones,'” plagued the area for decades but even with assurances that the reports were "doubtless without foundation," city officials and families alike had missed a few people when clearing out the city's first cemetery. ${ }^{282}$

\footnotetext{
278 “City vs. Terwilliger,” 1854-1887, A2001-059, 2012-20, Cemetary, 1/8, City of Portland Archive. 279 “Early Cemeteries," Morning Oregonian, April 26, 1887, p. 2.

280 "Many Pioneers Lie Under Third and Burnside Sts," undated newspaper clipping, Vertical Files, Portland - Cemeteries, Oregon Historical Society Research Library. 281 Ibid.

282 “Early Cemeteries," Morning Oregonian, April 26, 1887 p. 2.
} 
Human remains, when not in a sanctioned, organized burying ground, are surprisingly easy to lose. Sometimes we know their names and identities - Marks Friedman sold matzoth in Portland until he died in 1879 - but sometimes their identities, lives, and stories are lost to time, like the identity of the skull found by the workman on Burnside Street. Physical spaces of death provide an informative lens into the lives of people from other times. In Portland, this story is one of conflict between a citizenry who needed burial space and city officials who could not or would not attend to this need. Private enterprise did eventually meet the need of Portlanders, but both Colburn Barrell and the founders of Riverview Cemetery worked for the betterment of the city, mostly regardless of profit. In the quest for a "place more appropriate," Portlanders were gifted many beautiful burying grounds which signaled their sophistication and development to the rest of the world; these important necessities were provided by benevolent capitalists - not the city government. 
Conclusion

One-hundred years and three days after the initial reinterment of Jason Lee, hundreds of visitors came to celebrate, again, the reinterment of his mortal remains in Salem. There were many important people who attended: "a mayor, a university president, historians, clergy, children, parents and descendants of pioneers with ties to Lee."283 Again, just like at the original reinterment, those who attended lauded the actions of Lee, "his influence was beyond measure," "Lee was more than a pastor," he "created the beginnings of what would become the state of Oregon." ${ }^{284}$ Just eighteen days later, vandals toppled or smashed seventy-seven markers, including that of prominent missionary member Gustavus Hines. ${ }^{285}$ Even with Lee's colonial legacy cemented in the historical narrative, his marker, and those of the other missionaries, were not safe from the whims of teenaged miscreants.

Cemeteries, bones, and markers may be long-lasting, but memory and identity are much more mutable. Oregonians reinterpreted the actions of Jason Lee decades after his death in a way that fit within the clean narrative of settlercolonialism at the cemetery bearing his name. The reburial of Samuel R. Thurston helped cement Salem's place as Oregon's capital, at a time when this was far from a certainty.

In the choosing of physical spaces of cemeteries, Oregonians grappled with the question of who had the obligation to provide for services that benefitted the

\footnotetext{
283 Timothy Alex Akimoff, “Crowd honors pioneer's memory,” Statesman Journal, June 19, 2006, p. 13. 284 Ibid.

${ }^{285}$ Capi Lynn, “Vandals trash Lee Mission Cemetery," Statesman Journal, July 7, 2006, p.1-2.
} 
entire community; where Salem had a quick and definitive answer, Portland struggled for nearly fifty years. Cemeteries, and the stories of those buried within them, are products of the time and the people who created them; in some cases, like Salem, cemeteries are highly curated and intentional interpretations of death space, and in other cases, as in Portland, they are a series of failures which highlighted the challenges of creating Eastern-American-style living space out of the natural landscape.

Both in Salem and Portland, anxious settlers signaled their development with their places of death. The shape and size of Lone Fir Cemetery and the Odd Fellows Rural Cemetery, remarkably similar, demonstrated the desire of these settlers to be perceived as modern and advanced to the rest of the western world. Riverview, the largest cemetery platted in Portland at the time of its founding, closely copied the shape and design of Green-wood or Mount Auburn, its founders explicitly drawing comparisons between their own efforts and the efforts of cities they sought to emulate in other arenas.

The development of cemeteries in Portland and Salem was closely related to the process of colonization on the West Coast. In the quest for urbanized cities like those on the East Coast, residents of these cities sought to provide all the services that were available across the continent. Cemeteries, a way to care for the dead, were an important aspect of this urbanization, development, and colonization of the West. For Salem, this development came quickly because of the organized efforts of 
a benevolent group. For Portland, this important aspect of urbanization took much longer and only developed when the financial future of the city was at risk.

The creation of these spaces was not centrally planned or monolithically representative of how all people were treated in the culture of the day. That "everything pertaining to the departed," was "sacred," and that none would, as the editor of the Statesman related, allow "a wanton insult to the memory [of the dead], even of one who in life failed to command esteem or respect,"286 are commonly expressed sentiments. However, the way that the remains of those who were interred at the Oregon State Hospital were treated after their passing provides a silent counter-narrative: all are sacred in death, but some are more sacred than others. Further, the treatment of the remains of the Native children who attended the Methodist mission demonstrate that the goals of the Methodist missionaries, to save as many souls as possible, eventually fell to the possibility of financial gain that came along with Euro-American resettlement.

Death, memory, and cemeteries are intrinsically interconnected. Examining the forces which create these spaces is essential to understanding how the narrative of colonization effected and still effects our everyday life. Cemeteries are first places for mourning and reflection, but they are also places worthy of critical contemplation long after the last person is interred inside. This contemplation reveals that they are places where anxieties, failings, and successes all intertwine to

286 “Cemeteries," Weekly Oregon Statesman, May 22, 1860, p. 2. 
create a wholly-mortal space in the physical landscape, one rich with the stories we wish to tell about ourselves and the ones we once wished to forget. 
References

Abbott, Carl. Portland: Planning, Politics, and Growth in a Twentieth-century City. Lincoln: University of Nebraska Press, 1983.

Abbott, Carl. How Cities Won the West Four Centuries of Urban Change in Western North America. Albuquerque: Univ. of New Mexico Press, 2008.

Abbott, Carl. Portland in Three Centuries: The Place and the People. Corvallis: Oregon State University Press, 2011.

Adas, Michael. "From Settler Colony to Global Hegemon: Integrating the Exceptionalist Narrative of the American Experience into World History." The American Historical Review 106, no. 5 (December 2001): 1692-720. doi:10.1086/ahr/106.5.1692.

Addis, Cameron. "Whitman Massacre." Oregon Encyclopedia. 2018. Accessed June 3, 2018.

Ariès, Philippe. The Hour of Our Death: The Classic History of Western Attitudes toward Death over the Last One Thousand Years. New York: Alfred A. Knopf, 1981. 
Ashby, Chris, and Nate Orton. Lone Fir Cemetery. Portland, OR: Abandoned Bike, 2011.

Atwood, A. The Conquerors; Historical Sketches of the American Settlement of the Oregon Country, Embracing Facts in the Life and Work of Rev. Jason Lee ... Cincinnati: Jennings and Graham, 1907.

Bagley, Clarence B. "George Wilkes." Washington Historical Quarterly 5, no. 1 (January 1914).

Bailey, Margaret J. The Grains, or Passages in the Life of Ruth Rover: With Occasional Pictures of Oregon, Natural and Mortal. Edited by Evelyn Leasher and Robert J. Frank. Corvallis: Oregon State Univ. Press, 1986.

Binas, Joshua. "McLoughlin Land Survey Claim, 1843." Oregon History Project. 2018. Accessed June 3, 2018. https://oregonhistoryproject.org/articles/historicalrecords/mcloughlin-land-survey-claim-1843/\#.WxTNw0gvw2w.

Binder, Andrea Mary. "Deep Is the Grave, and Silent": Death and Mourning on the Oregon-California Trails. Master's thesis, University of Wyoming, 2011. 
Boag, Peter. "Death and Oregons Settler Generation: Connecting Parricide, Agricultural Decline, and Dying Pioneers at the Turn of the Twentieth Century." Oregon Historical Quarterly 115, no. 3 (Fall 2014): 344-79. doi:10.5403/oregonhistq.115.3.0344.

Brosnan, Cornelius J. Jason Lee, Prophet of the New Oregon. New York: Macmillan, 1932.

Brown, J. Henry, comp. The Salem Directory for 1871. Salem: Snyder \& Cook, 1871.

Browne, Sheri Bartlett. "Frances Fuller Victor." The Oregon Encyclopedia. 2018. Accessed October 3, 2018. https://oregonencyclopedia.org/articles/victor_frances_fuller/\#.W7UWPGhKhPY.

Byrd, Dean H., Stanley R. Clarke, and Janice M. Healy, comps. Oregon Burial Site Guide. Portland, Or.: Binford \& Mort Pub., 2001.

Chapman, Judy. "Willamette Mission." The Oregon Encyclopedia. 2018. Accessed June 2, 2018. https://oregonencyclopedia.org/articles/jason_lee_mission_willamette_mission/\#. WxMDgUgvw2w. 
Come Together Home. Directed by Ivy Linn. Portland, OR: Self-published, 2009. DVD.

Cooper, Karen Coody. Spirited Encounters American Indians Protest Museum Policies and Practices. Lanham, MD: AltaMira Press, 2008.

Cooper, Susan. Rural Hours. New York, 1851.

Dearly Departed: A Benefit for Friends of Lone Fir Cemetery. K Wheel Records, 2008, CD.

Edwards, G. Thomas. "Benjamin Stark, the U.S. Senate, and 1862 Membership Issues, Pt. I." Oregon Historical Quarterly 72, no. 4 (December 1971).

Eiselein, E. B. "Death in Pueblo and Athabascan Cultures." Native American Netroots. March 18, 2016. Accessed March 6, 2018. http://nativeamericannetroots.net/diary/1467.

Emery, George, and J. C. Herbert. Emery. Young Mans Benefit: The Independent Order of Odd Fellows and Sickness Insurance in the United States and Canada 18601929. Montreal: McGill-Queens University Press, 1999. 
Fabian, Ann. The Skull Collectors: Race, Science, and Americas Unburied Dead. Chicago, IL: University of Chicago Press, 2010.

Faust, Drew Gilpin. This Republic of Suffering: Death and the American Civil War. New York: Alfred A. Knopf, 2012.

Fine-Dare, Kathleen S. Grave Injustice: The American Indian Repatriation Movement and NAGPRA. Lincoln: University of Nebraska Press, 2002.

Friendman, Elaine. "Congregation Neveh Shalom." The Oregon Encyclopedia. 2017. Accessed March 12, 2018.

https://oregonencyclopedia.org/articles/congregation_neveh_shalom/\#.WhtnSUqn FPa.

Fuller, Tom, and Christy Van Heukelem. Salem. Charleston, SC: Arcadia Publishing, 2009.

Gay, Theressa. Life and Letters of Mrs. Jason Lee: First Wife of Rev. Jason Lee of the Oregon Mission. Portland, Or.: Binford \& Mort, 1936.

Goeres-Gardner, Diane L. Necktie Parties: A History of Legal Executions in Oregon, 1851-1905. Caldwell, ID: Caxton Press, 2005. 
Halliday, Stephen. "Death and Miasma in Victorian London: An Obstinate Belief." British Medical Journal 323, no. 7327 (December 2001): 1469-471. doi:10.1136/bmj.323.7327.1469.

Harrison, Robert Pogue. The Dominion of the Dead. University of Chicago Press, 2010.

Hines, Gustavus. A Voyage round the World: With a History of the Oregon Mission . To Which Is Appended a Full Description of Oregon Territory, Its Geography, History and Religion; Designed for the Benefit of Emigrants to That Rising Country. Buffalo: G.H. Derby and, 1850.

Hines, Gustavus. Oregon and Its Institutions: Comprising a Full History of the Willamette University, the First Established on the Pacific Coast. New York: Carleton \& Porter, 1868.

Hines, H. K. Missionary History of the Pacific Northwest: Containing the Wonderful Story of Jason Lee, with Sketches of Many of His Co-laborers, All Illustrating Life of the Plains and in the Mountains in Pioneer Days. Portland: H.K. Hines, 1899. 
Historical Atlas Map of Marion \&amp; Linn Counties, Oregon. San Francisco: Edgar Williams \&, 1876.

Hopkins, Caitlin Galante-DeAngelis. The Shadow of Change: Politics and Memory in New Englands Historic Burying Grounds, 1630-1776. PhD diss., Harvard University, 2014.

Hoxie, Frederick E. "Retrieving the Red Continent: Settler Colonialism and the History of American Indians in the US." Ethnic and Racial Studies 31, no. 6 (September 2008): 1153-167. doi:10.1080/01419870701791294.

Jetté, Melinda Marie. At the Hearth of the Crossed Races a French-Indian Community in Nineteenth-century Oregon ; 1812-1859. Corvallis: Oregon State Univ. Press, 2015.

Johnston, Harold Whestone. The Private Life of Romans. Rome: Scott, Foresman and Company, 1903. Accessed March 6, 2018. http://www.forumromanum.org/life/johnston_14.html\#465.

Kammen, Michael G. Digging up the Dead: A History of Notable American Reburials. Chicago: University of Chicago Press, 2010. 
Klein, Kerwin Lee. Frontiers of Historical Imagination: Narrating the European Conquest of Native America, 1890-1990. Berkeley: University of California Press, 1999.

Leavenworth, E. W. History, Incorporation, Rules and Regulations of Oakwood Cemetery .. Syrcuse: J.G.K. Truair, 1860.

Lee, Daniel, and J. H. Frost. Ten Years in Oregon. New York: J. Collord, 1844.

Lee, Jason. "Diary of Reverend Jason Lee - III." The Quarterly of the Oregon Historical Society 17, no. 4 (December 1916).

Lewis, David. "Mounds of the Tualatin-Yamhill Kalapuyan Area." NDNHISTORY RESEARCH : Indigenous, Public \& Critical Essays. August 1, 2017. Accessed July 6, 2018. https://ndnhistoryresearch.com/2017/08/01/mounds-of-the-tualatinyamhill-kalapuyan-area.

Limerick, Patricia Nelson. The Legacy of Conquest: The Unbroken Past of the American West. New York: W.W. Norton \& Company, 1987.

Loewenberg, Robert J. Equality on the Oregon Frontier: Jason Lee and the Methodist Mission, 1834-43. Seattle: Univ. of Washington P., 1976. 
Lonetree, Amy. Decolonizing Museums: Representing Native America in National and Tribal Museums. Chapel Hill: University of North Carolina Press, 2012.

MacColl, E. Kimbark. The Shaping of a City: Business and Politics in Portland, Oregon, 1885-1915. Portland, Or.: Georgian Press, 1976.

Mahoney, Barbara. "Asahel Bush, 1824-1913." The Oregon Encyclopedia. 2018. Accessed September 16, 2018.

https://oregonencyclopedia.org/articles/bush_asahel_1824_1913_/\#.W57hWOhKh PZ.

Martineau, Harriet. Retrospect of Western Travel. London: Saunders and Otley, 1838.

Mathiesen, Johan. Mad as the Mist and Snow: Exploring Oregon History through Its Cemeteries. Ashland, OR: Ashland Creek Press, 2011.

Mathiesen, Johan. Hey Darlin: Epitaphs from the Oregon Territory. Portland, OR: DeadManTalking, 2012. 
Mathiesen, Johan. Lone Fir: The Cemetery: A Guide \&amp; History. Portland, OR: DeadManTalking, 2012.

Mattson, Sylvia. Missionary Footpaths: The Story of Anna Maria Pittman Lee (Mrs. Jason Lee). Salem: Mission Mill Museum, 1978.

McKay, Floyd. "Oregon Statesman." The Oregon Encyclopedia. 2018. Accessed September 16, 2018. https://oregonencyclopedia.org/articles/oregon_statesman/\#.W57en-hKhPa. Meyer, Richard E. Cemeteries and Grave Markers: Voices of American Culture. Ann Arbor: UMI Research Press, 1989.

Moffat, Riley M. Population History of Western U.S. Cities and Towns, 1850-1990. Metuchen, NJ: Scarecrow Press, 1996.

Nelson, Vera Joyce, and Helen Krebs Smith. With Her Own Wings: Historical Sketches, Reminiscences, and Anecdotes of Oregons Pioneer Women. Portland: Beattie and, 1948. 
Nicolay, C. G. The Oregon Territory: A Geographical and Physical Account of That Country and Its Inhabitants, with Outlines of Its History and Discovery. London: C. Knight, 1846.

Nokes, Greg. "Peter Burnett (1807-1895)." The Oregon Encyclopedia. 2018. Accessed June 3, 2018. https://oregonencyclopedia.org/articles/burnett_peter/\#.WxRI3Ugvw2w.

Platt, Amy. "Anna Maria Pittman Lee (1803-1838)." Oregon History Project. Accessed May 13, 2018. https://oregonhistoryproject.org/articles/anna-mariapittman-lee-1803-1838/\#.WMN7q2_yvIU.

Rawson, Michael. Eden on the Charles: The Making of Boston. Cambridge, MA: Harvard University Press, 2014.

Rosaldo, Renato. Culture \&amp; Truth: The Remaking of Social Analysis. Boston: Beacon Press, 1989.

Rosenwaike, Ira. Population History of New York City. Syracuse: Syracuse Univ. Press, 1972. 
Sachs, Aaron. Arcadian America: The Death and Life of an Environmental Tradition. New Haven: Yale University Press, 2014.

Sanders, Judith A., Mary K. Weber, and David Ray. Brauner. Willamette Mission Archeological Project: Phase III Assessment. Corvallis: Dept. of Anthropology, Oregon State University, 1983.

Shepard, Cyrus. Diary of Cyrus Shepard: March 4, 1834-December 20, 1835. Vancouver: Clark County Genealogical Society, 1986.

Sloane, David Charles. The Last Great Necessity: Cemeteries in American History. Baltimore, MD: Johns Hopkins University Press, 1991.

Stott, Annette. Pioneer Cemeteries: Sculpture Gardens of the Old West. Lincoln: University of Nebraska Press, 2008.

Suval, John. "'The Nomadic Race to Which I Belong": Squatter Democracy and the Claiming of Oregon." Oregon Historical Quarterly 118, no. 3 (Fall 2017): 306-37. doi:10.5403/oregonhistq.118.3.0306.

The Picturesque Pocket Companion, and Visitors Guide, through Mount Auburn. Boston: Otis, Broaders and, 1839. 
Townsend, John Kirk. Narrative of a Journey across the Rocky Mountains: To the Columbia River, and a Visit to the Sandwich Islands, Chili, \&amp;c.: With a Scientific Appendix. Philadelphia: Henry Perkins, 1839.

Trafzer, Clifford. "The Legacy of the Walla Walla Council, 1855." Oregon Historical Quarterly 106, no. 3 (Fall 2005): 389-411.

Vaughn, Chelsea K. "Killing Narcissa: Race, Gender, and Violence in Recreations of the Whitman Incident." Oregon Historical Quarterly 115, no. 3 (Autumn 2014): 380413. doi:10.5403/oregonhistq.115.3.0380.

Verdery, Katherine. The Political Lives of Dead Bodies: Reburial and Postsocialist Change. New York: Columbia University Press, 1999.

Whaley, Gray H. "'Trophies' for God': Native Mortality, Racial Ideology, and the Methodist Mission of Lower Oregon." Oregon Historical Quarterly 107, no. 1 (April 2006): 6-35.

Whaley, Gray H. Oregon and the Collapse of Illahee: U.S. Empire and the Transformation of an Indigenous World, 1792-1859. Chapel Hill, NC: University of North Carolina Press, 2010. 
Wilkes, George. An Account and History of the Oregon Territory: Together with a Journal of an Emigrating Party across the Western Prairies of America and to the Mouth of the Columbia River. London: W. Lott, 1846.

Winslow, Walter C. "Contests over the Capital of Oregon." Quarterly of the Oregon Historical Society 9, no. 2 (June 1908).

Yarrow, H. C. Introduction to the Study of Mortuary Customs among the North American Indians. Washington, 1880. https://archive.org/details/introductiontost00yarr. 